\title{
Clean Solid Biofuel Production from High Moisture Content Waste Biomass Employing Hydrothermal Treatment
}

\author{
Peitao Zhao ${ }^{1,2,3}$, Yafei Shen ${ }^{3}$, Shifu Ge ${ }^{2}$, Zhenqian Chen $^{2}$ and Kunio Yoshikawa ${ }^{3}$ \\ ${ }^{1}$ School of Electric Power Engineering, China University of Mining and Technology, Xuzhou \\ 221116, PR China \\ ${ }^{2}$ Key Laboratory of Energy Thermal Conversion and Control of Ministry of Education, School of \\ Energy and Environment, Southeast University, Nanjing 210096, PR China \\ ${ }^{3}$ Department of Environmental Science and Technology, Tokyo Institute of Technology, Kanagawa \\ 226-8503, Japan \\ E-mail address: pt.zhaoseu@gmail.com (ZHAO) yoshikawa.k.aa@m.titech.ac.jp (YOSHIKAWA) \\ Tel: +81-45-924-5507 Fax: +81-45-924-5518 \\ ge1962@126.com (GE) zqchen@seu.edu.cn (CHEN) \\ Tel: +86-25-83792379 Fax: +86-25-5771-4489
}

\begin{abstract}
Our society currently faces three challenges, including resource depletion, waste accumulation and environmental degradation, leading to rapidly escalating raw material costs and increasingly expensive and restrictive waste disposal legislation. This work aims to produce clean solid biofuel from high moisture content waste biomass (bio-waste) with high nitrogen $(\mathrm{N}) /$ chlorine $(\mathrm{Cl})$ content by mild hydrothermal (HT) conversion processes. The newest results are summarized and discussed in terms of the mechanical dewatering and upgrading, dechlorination, denitrification and coalification resulting from the HT pretreatment. Moreover, both the mono-combustion and co-combustion characteristics of the solid fuel are reviewed by concentrating on the pollutants emission control, especially the NO emission properties. In addition, the feasibility of this HT solid biofuel production process is also discussed in terms of "Energy Balance and economic viability". As an alternative to dry combustion/dry pyrolysis/co-combustion, the HT process, combining the dehydration and decarboxylation of a biomass to raise its carbon content aiming to achieve a higher calorific value, opens up the field of potential feedstock for lignite-like solid biofuel production from a wide range of nontraditional renewable and plentiful wet agricultural residues, sludge and municipal wastes. It would contribute to a wider application of HT pretreatment bio-wastes for safe disposal and energy recycling.
\end{abstract}

Keywords: hydrothermal treatment, waste biomass utilization, coalification, denitrogenation, dechlorination 


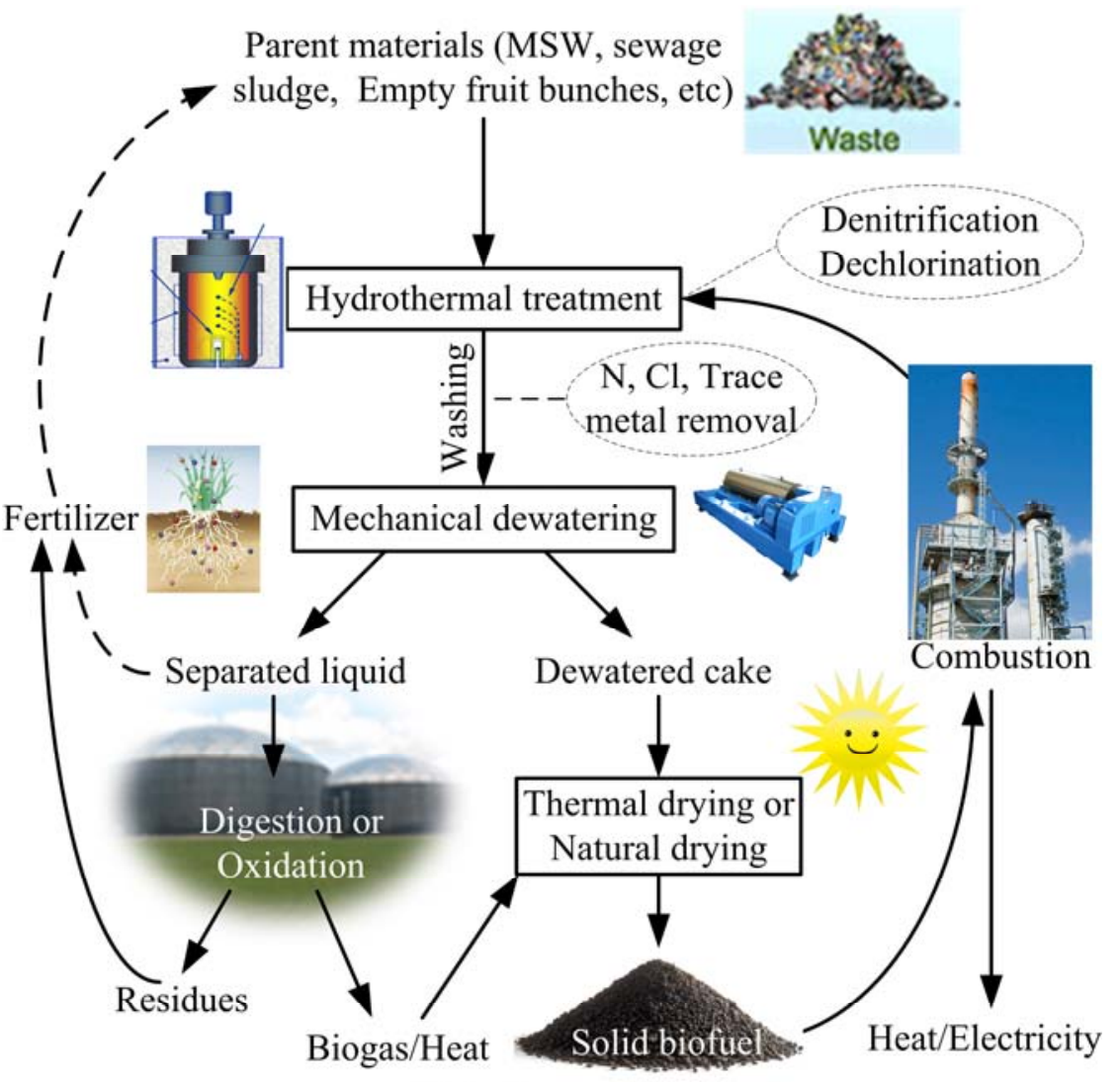

\section{Table of Contents}

Clean Solid Biofuel Production from High Moisture Content Waste Biomass Employing

Abstract.

Graphical abstract

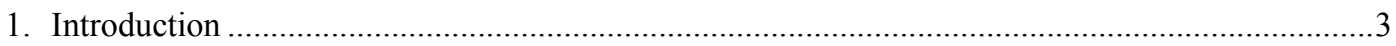

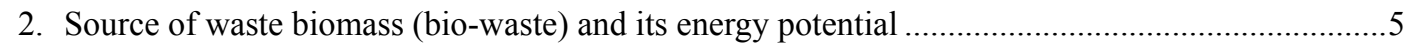

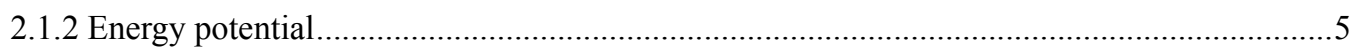




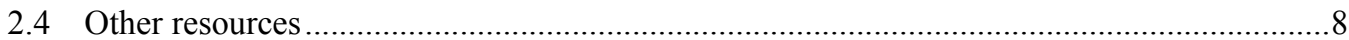

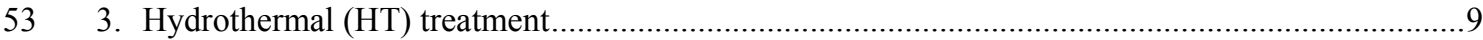

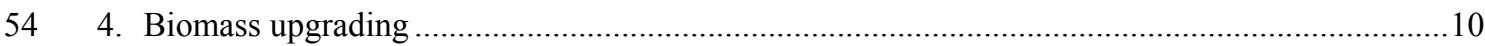

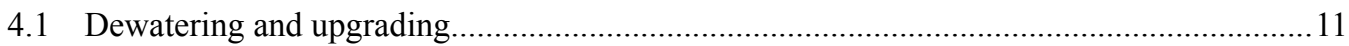

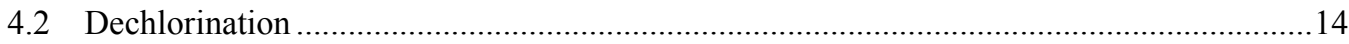

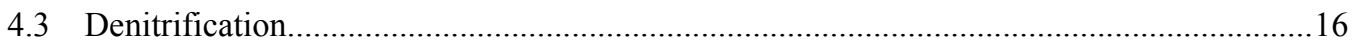

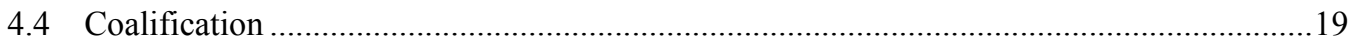

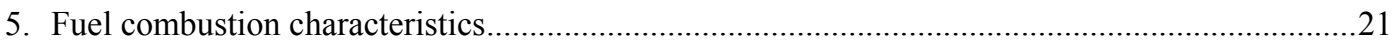

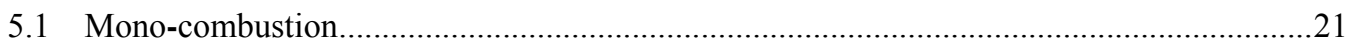

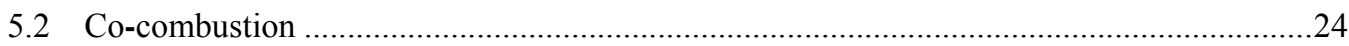

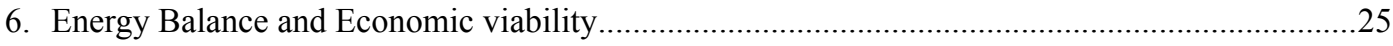

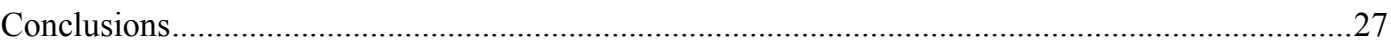

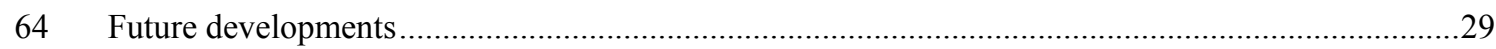

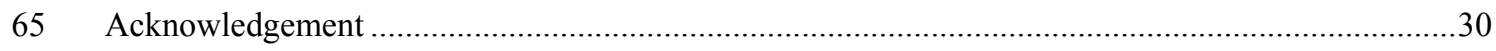

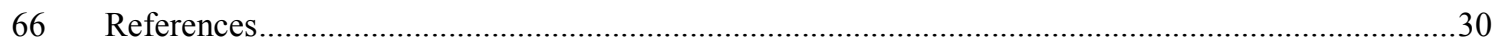

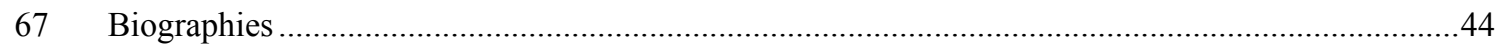

\section{Introduction}

Until now, the fossil fuel, which is regarded as non-renewable and the main energy source all over the world, is diminishing fast [1,2]. At the same time, the worldwide fuel demand keeps increasing dramatically (29.75 billion barrels oil in 2011 and projected to be 34.90 billion barrels in 2030 [3]) and correspondingly the fossil fuel reserve (about 1653 billion barrels oil at the end of 2011 [3]) decrease rapidly $[4,5]$. These historical and anticipated increases in primary energy consumption have amplified concerns about the environmental consequences of continued fossil fuel extraction and use [6]. Therefore, more and more attention has been given to extract energy from the alternative cheap and renewable energy resources with little or no environmental impact [7]. The status/challenge of energy demand, development of the renewable energy and environment of the global and some specific countries or region have been summarized by many researchers, including Dincer [8], Kaygusuz [9], Omer [10], Asif [11], Panwar [12], Bugaje [13], Chang [14], Budzianowski [15-17], etc. They clearly show that among renewable energy, biomass energy seems to be one of the most efficient and effective solutions to energy shortage and some energy-related problem, e.g. $\mathrm{CO}_{2}$ emission reduction because of its carbon-neutral nature.

However, the heterogeneity of biomass causes difficulties in energy recovery technologies such as anaerobic digestion and combustion [18]. Direct combustion and co-combustion of biomass with low rank coals is widely accepted as less risky, less expensive, time-saving options to utilize biomass energy [19]. Several experts indicated that direct combustion is not so satisfying because of some inherent drawbacks of biomass, including the high moisture and oxygen contents, and high alkaline earth metal content [19-21]. Moreover, biomass are always of low bulk densities ( $\sim 150$ $\mathrm{kg} / \mathrm{m}^{3}$ ), which accounts for its low volume-based heating value, requirement of huge storage, expensive transportation, feeding control [19]. On the other hand, the intensified use of biomass 
from crops is limited because the finite agricultural land would generate competition between food supply and bioenergy production [22-24], finally resulting in increasing in food prices or even food shortage [18]. Therefore, comprehensively considering the challenges-resource depletion, waste accumulation and environmental degradation, energy recycling from biomass waste (bio-waste) has received more and more attractive recently because it provides a large volume reduction, hazard reduction, and heavy metals controlling and the release of the environmental burden. Just taking sewage sludge as an example, the publications related on sewage sludge utilization have been grown exponentially in Elsevier from 2000 (S1).

These wastes are generally generated from industrial activities such as sewage sludge from wastewater treatment plants, mycelia wastes from medicine production, empty fruit bunches (EFB) from the production of palm oil, and distilled spirits lees from beverage production or agricultural residual such as driftwood, or material from households, like kitchen residues and garden cuts [18, 25], as well as waste from municipal, including the municipal solid waste (MSW), hospital wastes. However, these bio-wastes are usually of high moisture content (around 56 wt.\% for MSW and 80 wt.\% for sewage sludge), high nitrogen $(\mathrm{N})$ (e.g. sewage sludge: $1.0-10.0$ wt.\% at dry basis (db) [26-31]; mycelial waste: 2.0-9.0 wt.\% (db) [32]; distilled spirits lees: about 3 wt.\% (db) [33]) or chlorine $(\mathrm{Cl})$ content (as high as $1.6 \mathrm{wt} \%$ (db) for MSW because of the existence of plastic [34]) [33]. Direct incineration encounters various problems, such as hard to ignite, unsteady and unstable combustion, incomplete combustion, and huge amount of gaseous pollutants due to the high moisture content. Besides, the $\mathrm{N}$ and sulphur (S) contained in feedstock will be finally converted into $\mathrm{NO}_{x}$ and $\mathrm{SO}_{x}$ causing a secondary pollution, such as photochemical smog, acid rain, greenhouse emission and ozone depletion [35-39]. High $\mathrm{S}$ and $\mathrm{Cl}$ contents would cause corrosion problems, subsequently reducing the combustion facilities' lifetime and increasing the operating cost [40]. The $\mathrm{Cl}$ contents can also increase the risk to emit toxic dioxins and furans [40, 41]. Alkaline metal, such as potassium $(\mathrm{K})$, is also a concern for furnace corrosion and lowers the ash melting temperatures, which therefore causes severe fouling and agglomeration inside boilers [18, 35, 42-46]. For other thermal conversion technologies, such as pyrolysis and gasification, a pre-drying process is necessary to improve the thermal efficiency, which would therefore significantly increase the operating cost and become unacceptable, especially for the developing countries [47-52]. Thus, a pretreatment is essential to upgrade the biomass feedstock (such as improving energy density, removing $\mathrm{K}$ and $\mathrm{Cl}$ prior to final utilization) to homogenize different biomass into high value-added products, including biodiesel, alcohol, biogas, bio-solid fuels and animal feed in order to utilize them cost-efficiently and environment-friendly.

Recently, hydrothermal (HT) treatment (wet torrefaction, hot compressed water, or hot water pretreatment) has been introduced and applied in the field of wastes to energy (WTE). Some works focusing on specific issue have been done to investigate the feasibility of solid biofuel (hydrochar) production from bio-waste by employing the HT pretreatment and the combustion characteristics of solid biofuel [2, 34, 53-75]. However, the research and development of applying the HT in solid biofuel production, especially in the clean solid biofuel, has not been summarized. This review will mainly focus on the clean solid biofuel production from bio-waste to realize " $3 \mathrm{R}$ " rule (reduce, reuse and recycle) by employing $\mathrm{HT}$ pretreatment. It concentrates on the water removal, $\mathrm{N}$ and $\mathrm{Cl}$ 
transformation behavior during the HT pretreatment, the biofuel combustion characteristics, and the economic variability of the HT solid biofuel production process. Moreover, the disadvantages, challenges this technology is facing, and the expected future improvements are also discussed aiming to provide some clues for further study. The paper is organized as follows: Section 2 provides a brief introduction of potential bio-wastes using sewage sludge, MSW and EFB as representatives. A short research progress in applying HT as a pretreatment method in bio-waste dewatering and upgrading is given in Section 3. Section 4 concentrates on fuel upgrading, the $\mathrm{N}$ and $\mathrm{Cl}$ transformation behavior, and coalification during the HT treatment. Section 5 discusses the mono-combustion and co-combustion characteristics in terms of pollutants emission in order to investigate the technical feasibility of solid biofuel production by HT treatment, and finally in Section 6, a mass and energy balance analysis was carried out and the economic feasibility of the HT solid biofuel production process was evaluated by comparing to conventional thermal drying. Moreover, to provide an objective view, results from theoretical calculation and simulation by other researchers are also discussed and presented.

\section{Source of waste biomass (bio-waste) and its energy potential}

\subsection{Sludge}

\subsubsection{Sources}

Treatment of municipal wastewater results worldwide in producing large amounts of sewage sludge. The sludge treatment and disposal has been a severe environmental problem because of this huge yield. In China, about 20.76 million tons sludge with $80 \%$ water content has been produced in $2010[52,76]$. Moreover, this amount will be much higher according to the China's 12th Five-Year Construction Plan for National Urban Wastewater Treatment and Recycling Facilities [52]. Table 1 summarizes the sludge production of some typical countries. It is organizationally, technically, and economically hardly possible to prevent or strongly reduce the amount of municipal wastewater because of the urbanization, industrialization, and growth in population [77]. Sludge volumes will grow in the view of worldwide as countries grow in population and become wealthier. Theoretically, if the coverage and rate of wastewater treatment of some other middle-income countries, such as Brazil, China, reach the same level as high-income countries, the annual sludge production could be highly increased from 410,000 tons to over 4.4 million tons for Brazil and 3.2 million tons to 31 million tons for China according to Lux Research [78]. Also, the quality of the produced sewage sludge will not change significantly because a large part of these toxic pollutants originates from diffuse sources. Therefore, sewage sludge will remain a permanent waste problem that requires an appropriate solution [79]. Energy recovery from sewage sludge employing some technologies would be promising in terms of cost and environmental impact.

Table 1 Sludge production of some typical countries $\left(\times 10^{6} \mathrm{~kg} / \mathrm{year}\right)$, data derived from refs. [52, $80-82]$.

\subsubsection{Energy potential}

S2 shows some typical chemical composition and properties of untreated/digested sludge. Sewage sludge typically consists of a significant amount of nontoxic organic compounds, in general a 
combination of primary sludge and secondary (microbiological) sludge [52, 77]. It is highly heterogeneous and comprises a mixture of various organic and inorganic compounds. Sludge combustion has received worldwide attention and has been widely applied in some developed countries because it provides a large volume reduction, toxicity reduction, and heavy metals controlling of sludge treatment with energy recovering [83, 84]. In a research focusing on the energy potential of non-planation biomass resources in selected Asian countries, Bhattachearya et al. [85] has pointed out that the energy potential of wastewater in 2010 was to be 102, 200, 0.35 and $7.8 \mathrm{PJ}$ $\left(\times 10^{12} \mathrm{MJ}\right)$ for China, India, Sri Lanka and Thailand, respectively. Li et al. [86] also reported the same result when assessing the sustainable energy potential of non-plantation biomass resources in China.

On the other hand, sludge also contains variable quantities of other elements, including heavy metals. During thermal conversion, and especially gasification, most of the gaseous compounds of N, $\mathrm{S}$, and $\mathrm{Cl}$, appear as $\mathrm{H}_{2} \mathrm{~S}, \mathrm{NH}_{3}$, and $\mathrm{HCl}$ due to the reducing conditions applied. In the case of sludge exploitation for energy production through thermochemical processes, it is important to ascertain the mobility of these contaminants as they can potentially appear in all the three products formed (gas, char, tar) [87]. However, after HT pretreatment, the toxic element will retard in the solid part and part of organic hazardous elements, such as $\mathrm{N}, \mathrm{S}, \mathrm{Cl}$, can be removed or converted into inorganic part. During combustion, the harmful gaseous emission was reduced and the toxic element was remained in the ashes portion [76]. Thus, it would be environmentally friendly to produce an alternative fuel from sewage sludge by controlling the sludge moisture content with HT pretreatment.

\subsection{Municipal solid wastes (MSW)}

\subsubsection{Sources}

MSW represents a major source of biomass. Its production keeps increasing because of the rapid economic development, continuous urbanization, and improvements in the living standards. Its disposal is one of the vital issues in China due to the rapid urbanization [86]. Comparing to other biomass, MSW has an immediate advantage as a feedstock in that it is already collected at sites around the country and disposed in landfills. S3 shows general sources of MSW generated by households, commercial establishments, institutions, and municipal services etc. It consists of significant perishable organic wastes, glass, paper, plastics, metals etc. Table 2 provides data and projections from 1980 to 2030 for municipal waste generation of the Organization for Economic Co-operation and Development (OECD) and China mainland. It is estimated that in 2030 the mean municipal waste generation will be $1.8 \mathrm{~kg} /$ (capita-day) in the OECD region, about 0.75 $\mathrm{kg} /$ (capita day) in the BRICS (an association of emerging national economies: Brazil, Russia, India, China and South Africa) countries, and about $0.9 \mathrm{~kg}$ (capita.day) for the rest of the world (ROW). Total annual waste generation in 2030 is projected under the Baseline to be about 900 million tons for OECD countries, about 1 billion tons for the BRICS countries, and around 1.1 billion tons for the ROW [88]. Actually, some BRICS countries have already exceeded the estimated mean value of $0.75 \mathrm{~kg} /$ (capita-day). For China, although the generation rate in rural areas is largely unknown, it is already over $1.2 \mathrm{~kg} /$ (capita·day) in cities [88]. It is estimated that in 2030 the urbanization rate will 
212 be $68.7 \%$ in China; in India, the corresponding value is about 39.8\% [89]. The annual MSW

213 generation is expected to be at least 485 million tons (up 214\% from 2004) for China, and around 214250 million tons (up 130\% from 2001) for India [89]. Recently, the European Topic Centre on 215 Resource and Waste Management (ETC/RWM, 2007) also projects that the MSW generation within 216 the EU15 will increase by $33 \%$ to 2030 [88]; whereas it will grow by about $66 \%$ to 2030 for the new 217 EU member. The non-OECD area is expected to produce about $70 \%$ of the world's municipal waste, 218 mainly due to rising incomes, rapid urbanization, and technical and economic development [90]. In a 219 word, huge amount of MSW requires disposal and is available for the fuel production process 220 discussed. Moreover, it should be mentioned that the MSW does not include construction or 221 demolition debris or automobile scrap in this study.

222 Table 2 MSW generation within the OECD area and China mainland $\left(\times 10^{6} \mathrm{~kg} / \mathrm{year}\right)$

\subsubsection{Energy potential}

Recycling components of MSW is worthwhile if it confers economic advantage to purchasers of recycled materials or products, saves more fuel, and brings about environmental benefits or has lower cost than alternative methods of waste management [91, 92]. As indicated in Fig.1, about 50\% of components in MSW are combustible matters. The heating value of MSW can vary according to its composition (depending on the social habits and the economy of the region from which it is collected), the mean lower heating value is around $8 \mathrm{MJ} / \mathrm{kg}[50,91-93]$. Table 3 also shows fuel properties of MSW within some typical Asian countries, such as China, Japan and India. It indicates that the MSW are of high volatiles with a mass-based heating value higher than $15 \mathrm{MJ} / \mathrm{kg}$. It would be possible to utilize it with some thermal disposal methods, including combustion, pyrolysis and gasification, providing great benefits over traditional methods of disposing MSW. Moreover, its utilization has proved to be an effective option for reducing greenhouse gas emissions and has opened an era for co-utilizing wastes like sewage sludge, waste tyre, etc. Besides, the fuels produced from MSW can be very well used in many applications and replace some part of fossil fuels. It is projected that the energy potential of MSW is 91, 219, 47, 4.8 and 21.3 PJ for China, India, Philippines, Sri Lanka and Thailand in 2010, respectively [85]. However, some technical barriers need to be overcome in order to accelerate the clean, efficient use of MSW [56].

Fig.1 Typical composition of MSW, (a) United States, data adapted from U.S. EPA [94]; (b) by region, data derived from [95] "The World Bank, 2012, source: http://data.worldbank.org/"

Table 3 Fuel properties of MSW within some typical countries.

\subsection{Palm oil Empty Fruit Bunches (PEFB)}

\subsubsection{Sources}

Crude palm oil production is reaching 52.31 million tons per year globally in 2012 and Southeast Asia is the main contributor, with Indonesia accounting for $48.94 \%$, Malaysia $36.19 \%$, and Thailand $3.10 \%$ [96]. Oil palm is a multi-purpose plantation and it is also an intensive producer of biomass. After harvesting fresh fruit bunches from oil palm tree, these bunches are sterilized in a horizontal steam sterilizer to inactivate enzymes present in pericarp and loosen fruits from bunches. The sterilized bunches are fed into a rotary drum thresher in order to remove the sterilized fruit from 
bunches. These bunches without fruit are called EFB which are conveyed to the damping ground, whereas the sterilized fruits are further used as feedstock for palm oil production in palm oil extraction process by means of screw type press. The effluents from screw type press are nuts and fibers, which are separated from each other by cyclone. After this separation, nuts are cracked into shells and kernels. The former are solid waste and left unused, the latter are sent to the kernel oil mill [97]. Accompanying production of $1 \mathrm{~kg}$ of palm oil, about $4 \mathrm{~kg}$ of dry biomass waste are generated, including $1 / 3$ of palm oil empty fruit bunch (PEFB) and the other $2 / 3$ of oil palm trunks and fronds $[98,99]$. It was reported that Palm oil production in Malaysia reached 17.9 million tons in 2009, following Indonesia's record of 22 million tons [100]. Meanwhile, about 2.3 million tons of palm kernel cake (PKC) and 30 million tons of EFB and waste fruit fiber were simultaneous generated as by-products. Old palm trees are cut down and replaced by young trees at an interval of 25 years. Consequently, a large quantity of cut-down old palm trees is generated at times. It would be expected that the EFB will be one of the main bio-wastes.

\subsubsection{Properties}

Although the quantity of EFB available is in the sixth rank of all biomass, the energetic quality is high due to its high heating value and it is not yet mainly used as alternative fuel due to its high moisture (typically $60 \%$ w.b.) $[101,102]$ and volatile matter with low ash melting temperature [103]. Table 4 shows the proximate and ultimate analysis of EFB from typical countries, such as Indonesia, Malaysia and Thailand. It is obvious that the EFB can be used as fuel after removing the water. Yuhazri et al. [104] produced briquettes from EFB and waste paper and reported that the product is very durable, which makes it suitable for the end application of the briquettes requiring high durability during handling, transportation and storage. Jamari et al., and Yuliansyah et al. $[105,106]$ employed HT to upgrade EFB waste to produce exportable fuel and stated that the carbon value has been increased after the HT process. Although total energy produced from combustion of this solid biofuel was less than that of raw material, the use of this fuel still offers some other benefits. It is likely that HT will be widely applied to recover energy from EFB because of its high water removal ability in the near future.

Table 4 Proximate and ultimate analysis of EFB from Thailand, Indonesia, and Malaysia. Data adapted from ref. [102] for Indonesia, ref. [97] for Thailand, and ref. [103] for Malaysia.

\subsection{Other resources}

Considering widespread depletion of fossil fuels and gradually emerging consciousness about environmental degradation, the energy supply in the future has to come from renewable sources of energy. Although wastes are still largely under-utilized in most of the countries all over the world, their use is increasing rapidly; whilst costs (in real terms) drop significantly, resulting in as much as $15-18 \%$ contribution to national energy needs [107]. Biomass resources include wood and wood wastes, agricultural crops adapted their waste byproducts, MSW, animal wastes, waste from food processing and aquatic plants and algae [107]. Currently, the bio-waste disposal is a growing worldwide problem. Using bio-waste as feedstocks for bioenergy conversion processes is of particularly important because of its dual functions of waste reduction and energy production [108]. Potential bio-waste discussed in this study contain agricultural production wastes, agricultural 
processing wastes, crop residues, urban wood wastes, mill wood wastes, mycelial waste, distilled spirits lees, distiller grains, manure waste, paper sludge, algae, and urban organic wastes etc., which are typically of high moisture content and low heating value. Most of these wastes could be used for energy production through incineration and other process. Taking manure waste as an example, U.S. agricultural lands currently produce 35 million dry tons of sustainable animal manures [109, 110]. After conversion processing, an annual 5.3 million tons of swine manure could replace about 6.0 million barrels of petroleum-based fuels, equivalent to $2.1 \%$ of the annual consumption of petroleum in the U.S $[110,111]$. For China, India, Philippines, Sri Lanka and Thailand, the energy potential of manure wastes in 2010 is estimated to be $2095,374,4.9,6.5$ and 13 PJ respectively [85].

In the near future, it can be expected that bio-waste management and research related to innovative treatment methods will focus on three aspects: recovery and reuse of valuable products from waste, a complete solution to the disposal problem of waste, especially regarding the toxics, and acceptable costs. In this respect, it can be expected that the recovery of sustainable energy from bio-waste will become more and more of interest. Clean solid biofuel production from bio-waste with high moisture content employing HT pretreatment would be a technical feasibility and economical way to realize the $3 \mathrm{R}$ of waste treatment and disposal.

\section{Hydrothermal (HT) treatment}

HT, a process to treat biomass in water at temperature and under sufficient pressure to keep the water in either liquid or supercritical state [7, 112-114], offers significant advantages for biomass conversion, such as avoiding an energy-extensive drying process, high conversion efficiency and relatively low operation temperature among thermal methods $[19,115,116]$. It also offers a number of potential advantages over other biofuel production methods, including high throughputs, high energy and separation efficiency, the ability to use mixed feedstock like wastes and lignocellulose, the production of direct replacements for existing fuels, and no need to maintain specialized microbial cultures or enzymes. Moreover, it has unique possibilities in coordination with other biofuel processing techniques, including as a pretreatment step or post-fermentation reforming. In addition, the produced biofuels would be free of biologically active organisms or compounds, including bacteria, viruses, and even prion proteins because of the high temperatures involved [7].

In the aspect of energy efficiency, it obviates the need (capital, energy and time) for feedstock dewatering and drying as needed for other conversion methods such as gasification and pyrolysis [117]. It allows for integrated energy recovery because: (1) the high temperature effluent stream can be used to preheat the feedstock [118], (2) value-added products can be produced under a relative moderate condition [46, 113, 119-122]. Effective dehydration occurs in the presence of hot water [123, 124], which can serve as a solvent, a reactant, and even a catalyst or catalyst precursor [118]. In contrast to standard high-temperature carbonization reactions (e.g. pyrolysis), the HT process is an exothermic process and more energetically favorable [123, 125], as it liberates about a third of the combustion energy through dehydration at the same time forming condensed products [126]. Furthermore, the final carbonaceous product (hydrochar or solid biofuel) can easily be separated from the reaction solution, avoiding complicated drying schemes and costly isolation procedures. Depending upon the process conditions adopted, the carbon efficiency of HT can be very high, i.e. 
most of the starting carbon stays bound in the final solid product. In a word, application of the HT to WTE (waste to energy) is an attractive and effective way to minimize waste from the view point of energy consumption and mitigating greenhouse gas emissions [118, 123, 125, 127, 128]. This can be verified by the annually published research articles which grow exponentially as indicated in S4.

With the HT, liquefaction and gasification can be minimized at a comparably low temperatures ranging from 160 to $250{ }^{\circ} \mathrm{C}$ in order to increase the yield of a solid material termed solid biofuel [129-132]. This HT carbonization process can be used to convert a variety of feedstock to a solid fuel with carbon content similar to lignite at mass yields from 35 to $60 \%$. Currently, many biomass substrates, including cellulose [133], lignocellulosic biomass [134, 135], microalgae [136, 137], anaerobically digested maize silage [138], municipal solid waste [66, 72, 112, 139], distiller's grains [140], agricultural residues [141], and black liquor [142], have been applied in HT to gain fuels or materials. HT treatment of biomass generates liquid [30, 143-145], gaseous (mainly carbon dioxide), aqueous chemicals, and solid biofuel. Currently, most attention is paid to the liquid and gaseous products and many processes have been developed and optimized to improve the quality and yields of the target products [27, 143, 146-148]. However, further upgrading is still required because of its high acidity and complex composition [46]. Some others also focused on the biochar-a byproduct during waste biomass liquefaction, or gasification [46, 62, 112, 133, 149]. To investigate the properties of biochar derived by HT carbonization, the bio-waste feedstock were replaced with the pure biomass including glucose and cellulose. The results show that the biochar generated by HT carbonization exhibit some unique physicochemical properties compared to that produced by conventional carbonization. As such, they have been applied in several value-added applications [46, $113,119-122]$.

Undoubtedly, the HT treatment is a promising way to upgrade the biomass. Most of the works in the current literatures focused on the solid (hydrochar), liquid (oil), gas (hydrogen) fuel production at a relative high temperature and high pressure. In the case of bio-waste, they used model compounds (lignin, xylose, glucose and cellulose, etc) to investigate the reaction mechanisms and made great contribution to fully understand this technology. Interested readers can refer these excellent works [7, $113,119,120,123,124,133,134,144,147,150-155]$. In the field of WTE, some works have been done to investigate the feasibility of solid biofuel production from bio-waste and the fuel combustion characteristics $[2,34,53-75,156]$.

\section{Biomass upgrading}

As discussed, the high moisture content is the main obstacle for energy recovering from some bio-wastes, because it would directly reduce the heating value when using bio-waste as fuel supply. Water removal is therefore the first and also the key step for the utilization of these high moisture content bio-wastes. Normally, the method for water removal includes the mechanical dewatering (press filter, centrifuge, belt etc.) and forced evaporation with heat source; and the mechanical dewatering is much cheaper and simpler compared to the thermal forced evaporation. Hence, the most promising way is to pretreat the bio-wastes with some physical, chemical or thermal methods to improve the mechanical dewaterability and then remove the water with mechanical dewatering. Accordingly, three "bio-wastes to solid fuel" technologies, including combination of the thermal 
drying and physical mixing [84, 157], chemical conditioning [158, 159] and thermal pretreatment $[18,34,46,52,60,62,63,65,67,102,113,156,160-163]$, were proposed to produce solid fuel from sewage sludge, MSW etc.

Fig.2 presents a conceptual schematic of clean solid biofuel production from the high moisture content bio-wastes by HT and conventional thermal drying. As indicated in this figure, the main difference is the way to remove water, determining the cost of solid biofuel. Zhao et al. and Namioka et al. $[52,63]$ reported that the energy needed for the HT process was only about $30 \mathrm{wt} . \%$ of that consumed in the conventional thermal drying process. Details about the economy of the HT technology will be discussed in section 4 .

Fig.2 A conceptual schematic of clean solid biofuel from bio-wastes

As shown in Fig.2, the process of clean solid biofuel production by HT is mainly composed of the HT pretreatment, mechanical dewatering and natural drying. Sometimes, a washing process is also used to remove the harmful elements to meet the requirement of environmental policy. The high moisture bio-waste was first pretreated with a HT treatment. During this process, the dewaterability of the parent materials is improved and some of the $\mathrm{N}$ and $\mathrm{Cl}$ would be transformed from organic to inorganic state due to the hydrolysis, dehydration, decarboxylation, aromatization, and condensation polymerization etc., happening in the HT as discussion in section 3. Following with a mechanical dewatering procedure, most of the water contained in the parent raw materials and the water soluble harmful element are moved out from the solid part. The water content of the product is largely reduced from about $80 \mathrm{wt} . \%$ to $50 \mathrm{wt} . \%$ (sewage sludge, paper sludge and kimchi etc.) and $50 \mathrm{wt} . \%$ to 20 wt.\% (MSW) with a significant improvement in the energy density. After a thermal drying or natural drying within a few days, the powder coal-like solid biofuel can be recovered. Because the HT has removed a part of the harmful elements and also affected the transformation paths of $\mathrm{N}$ during the combustion resulting in reducing the NO emission, the solid biofuel produced from this process is called "clean solid biofuel". The effect of the HT on the dewaterability and the behavior of some typical harmful elements such as $\mathrm{N}, \mathrm{Cl}$ will be discussed in the following sections.

\subsection{Dewatering and upgrading}

The moisture distribution within a wet material shows strong correlation the bound water and the performance of many processes. Conceptually, the water existing in the wet materials was divided into four categories: free water, interstitial water, surface water and bound water [164]. The simplest definition is to divide into two parts: the "bound water", which is chemically or physically bounded to the bulk, and the "free water", which is the water same as the bulk water and is easily removed by mechanical methods [165]. The basic principle for improving the dewaterability is to force the "bound water" transformation into "free water" by conditioning. The thermal conditioning or thermal pretreatment has been known for many years to give an improvement in the sludge dewaterability [166]. Fisher and Swanwick reported that the sludge dewaterability was largely improved at a temperature above $150{ }^{\circ} \mathrm{C}$ [167] and could be further improved at a temperature above $180{ }^{\circ} \mathrm{C}$ [166]. After surveying a quantity of literature, Neyens and Baeyens [166] concluded that thermal pre-treatment methods are able to improve the dewaterability of both the undigested and digested sludge. The water content of the sludge cake can be reduced down to about 50 wt. $\%$ by a 
411 mechanical dehydration [168-172]. With a natural drying of $24 \mathrm{~h}$, it can be further reduced to about $41220 \mathrm{wt} . \%$ to produce the coal-like product. Two parameters, the temperature and holding time, were 413 thought to be the most important factors affecting sludge dewaterability in sludge thermal 414 conditioning [173]. As Fig.3 indicated, the moisture content of the dewatered HT product keeps 415 decreasing with both the temperature and holding time. However, the optimal conditions were a little 416 different from each other, for example $180{ }^{\circ} \mathrm{C}$ and 60 minutes by Zhao et al. [173], $190{ }^{\circ} \mathrm{C}$ and 30 417 minutes by Jiang et al. [168], $200{ }^{\circ} \mathrm{C}$ and 5 minutes [63], $170{ }^{\circ} \mathrm{C}$ and 90 minutes [174] and 418 temperature of $175{ }^{\circ} \mathrm{C}$ (holding time, not reported) [166], which could be attributed to the versatile 419 composition of sludge. Our previous results also showed that the optimal temperature for paper 420 sludge mechanical dewatering was $220{ }^{\circ} \mathrm{C}$ while that was $200{ }^{\circ} \mathrm{C}$ for the sewage sludge. It was 421 because the main component of the sewage sludge was protein and polysaccharide existing in flocs and cellular tissues while the fibers were the main composition of paper sludge. The flocs and cellular tissues were broken and released the bound water under a relative lower temperature (eg. $180^{\circ} \mathrm{C}$ ) by the thermal energy and pressure during the HT treatment $[175,176]$, resulting in the denaturing and destroying of the protein. While the optimal conditions for converting the fibers (rice bran) to protein and acid was about $200{ }^{\circ} \mathrm{C}$ and 30 minutes [177].

Fig.4 shows an overall dewatering performance (including the mechanical dewatering and the thermal evaporation) of the HT pretreated product. It clearly implies that the mechanical dewatering has been largely improved by the HT. Under a filtration pressure of $0.6 \mathrm{MPa}$, the moisture content of the HT pretreated paper sludge was reduced from about $85 \mathrm{wt} . \%$ to $60 \mathrm{wt} . \%$ within only 15 minutes. If increasing the pressure, the moisture could be lower than $50 \mathrm{wt} . \%$. It is also visible that the thermal drying performance has also been improved by the HT. Zhao et al. $[179,180]$ investigated the dying performance of the HT pretreated and untreated paper sludge with an air duct dryer at an air temperature of $30.4 \pm 0.4{ }^{\circ} \mathrm{C}$ and velocity of $1.34 \pm 0.04 \mathrm{~m} / \mathrm{s}$. The results show that the drying process mainly took place in the falling rate period and was mainly controlled by the diffusion properties of the inner structure of the product. The drying rate of the HT pretreated samples was twice that of the untreated paper sludge because of the improvement of the diffusion properties. Comprehensively considering the mechanical dewatering and the drying performance, the HT pretreatment was a promising method to remove water from the high moisture content bio-wastes.

Fig.3 Effect of the operating parameters on the sewage sludge dewatering: (a) Holding time; (b) Temperature. (References: Fisher and Swanwick [167], Jiang et al., [168] Zhao et al. [173] and Xun et al. [174] focusing on the sewage sludge; Areeprasert et al. [161] using paper sludge and Zhang et al. [163] using mycelial waste) (SRF: specific resistance to filtration)

Fig.4 Overall dewatering performance of the hydrothermal pretreated paper sludge (including the mechanical dewatering and thermal evaporation). Data from (Zhao, unpublished data)

The water removal from the high moisture bio-wastes would directly improve the gross heating value, thus increasing the possibility and quantity of energy recovery. Guo et al. [181] applied HT to upgrade the Victorian brown coal with a moisture of around 60-70 wt.\% at a temperature ranging from 200 to $300{ }^{\circ} \mathrm{C}$ and reported the solid concentration was highly improved from below $30 \mathrm{wt} . \%$ to $60 \mathrm{wt} . \%$. The heat value was also improved with an increase in carbon content and decrease in 
volatile matters. The results indicated that the HT pretreatment could not only improve the mechanical dewatering of parent materials, but also improve the fuel quality, such as the carbon content and energy density $[60,66,182,183]$. It is feasible for not only high moisture bio-wastes [46, $62,66,75,106,161,162]$, but also for the low rank coal [60, 181-184]. Fig.5 gives the variation of the calorific value of the HT pretreated product with the HT temperature. It can be also regarded as the variation of the mass based energy density with the temperature. It is evident that the heating value keeps increasing with the HT temperature independent of type of the raw materials. This upgrade became more significant especially in the high temperature zone of $220-380{ }^{\circ} \mathrm{C}$. However, the solid fuel recovery ratio, which was defined the proportion of the dry solid fuel (char) yield to the amount of the raw material, would also decrease with the temperature. To realize the maximum energy production, both the fuel yields and the heating value of the solid biofuel should be taken into account to optimize the operating conditions. Observing these curves, the results from Sakaguchi et al. [184] and Guo et al. [181] showed the same trend $v$ s the HT temperature under the same holding time of 30 minutes, verifying that the HT pretreatment could upgrade the low rank biomass and coal.

Furthermore, the collection and transportation of biomass is another hindrance for biomass utilization. Transportation costs largely depend on the distance travelled and the energy density, e.g. $\mathrm{MJ} / \mathrm{m}^{3}$, of the biomass being transported [185]. The similar issue applies to the utilization of the bio-wastes with high moisture and low energy density. However, the HT pretreatment has bright perspective with three main merits: 1) largely improving the dewaterability; 2) dramatic reduction in volume, especially for the MSW, sawdust, sewage sludge and leaves, thus improving the energy density; 3) energy densification. The volume based heating value of MSW has reported to be improved around 6.4-9.0 times in the HT conversion of the Japanese MSW, India MSW and Chinese MSW [66]. Similar results were also obtained by deriving the data present by Prawisudha et al., $[62,186]$ indicating that this volume based energy density was improved around 4-5 times after the HT pretreatment. As this data came from a long term running test in a commercial plant, it would be more reliable and significant than the previous one (Lu et al. [66]) for the optimization and design of the commercial plant. In the case of production of pellets of biochar from wood by the HT, Reza et al. [187] reported that the products exhibited favorable properties, including increased hydrophobicity, abrasion resistance, energy density, and mass density compared to pellets produced from raw pine or dry torrefied pine. Under a HT temperature of $260{ }^{\circ} \mathrm{C}$, the pellets produced had a volumetric fuel value of $70 \%$ greater than pellets produced from untreated pine $\left(38.8 \mathrm{MJ} / \mathrm{m}^{3}\right.$ vs. 22.8 $\mathrm{GJ} / \mathrm{m}^{3}$ ), a mass density of $1468 \mathrm{~kg} / \mathrm{m}^{3}$, and a higher heating value (HHV) of $26.4 \mathrm{MJ} / \mathrm{kg}$. Liu et al. [46] also stated that the energy densification increased with HT temperature, from a low value of 1.34 to 1.66 and from 1.33 to 1.55 for coconut fiber and eucalyptus leaves derived solid biofuel, respectively. The highest energy yield was achieved at the lowest temperature used.

Solid decomposition was significantly affected by reaction temperature more so than reaction time. Higher temperature resulted in lower hydrochar yields [188]. In Danso-Boateng's study, the equilibrium solid hydrochar (solid biofuel) yields (relative to the original dry mass used) were $74 \%$, $66 \%, 61 \%$ and $60 \%$ for primary sewage sludge (PSS) at 140, 170, 190 and $200{ }^{\circ} \mathrm{C}$ respectively, and $85 \%, 49 \%, 48 \%$ and $47 \%$ for synthetic faeces (SF) at 140, 160, 180 and $200{ }^{\circ} \mathrm{C}$ respectively. Energy contents of the solid biofuel from PSS carbonized at $140-200{ }^{\circ} \mathrm{C}$ for $4 \mathrm{~h}$ ranged from 21.5 to 23.1 
$\mathrm{MJ} / \mathrm{kg}$, and increased following carbonization [188]. Most recently, He et al. [156] employed HT to convert sewage sludge, with a moisture content of $85.7 \%$, to solid fuel at a temperature of $200{ }^{\circ} \mathrm{C}$ without prior drying. Elemental analysis showed that $88 \%$ of carbon was recovered while $60 \%$ of $\mathrm{N}$ and sulfur was removed after the HT carbonization process. Due to dehydration and decarboxylation reactions, oxygen/carbon atomic and hydrogen/carbon ratios reduced to 0.39 and 1.53 , respectively. Besides, longer carbonization time seemed to decrease oxygen containing functional groups while carbon aromaticity structure was increased, thereby rendering hydrochars highly hydrophobic.

With the HT treatment, the energy-intensive drying in conventional thermochemical treatment of bio-wastes due to its high moisture content could be avoided. The HT pretreatment of biomass with chemical addition may have desirable properties when co-fired in existing coal boilers. Recently, Kang et al. [142] indicated that formaldehyde was an effective additive in HT carbonization of black liquor. In his study, formaldehyde was utilized as a polymerization agent to perform HT carbonization of black liquor to produce solid fuel at a temperature around $220-285{ }^{\circ} \mathrm{C}$. The solid fuel produced in the presence of a $2.8 \mathrm{wt} . \%$ formaldehyde solution had 1.27-2.13 times higher yield, 1.02-1.36 times HHV, 1.20-2.31 times higher carbon recovery efficiency, 1.20-2.44 times higher total energy recovery efficiency, $0.51-0.64$ times lower sulfur content, and $0.48-0.89$ times lower ash content, compared to that prepared without formaldehyde. The HHV of solid fuel produced in the presence of formaldehyde ranged from 22 to $30 \mathrm{MJ} / \mathrm{kg}$, while the $\mathrm{HHV}$ of solid fuel produced at $285^{\circ} \mathrm{C}$ with and without formaldehyde was 1.90 and 1.57 times greater than that of the raw black liquor solid. These considerable improvements indicated that formaldehyde was an effective additive in HT carbonization of black liquor. Lynam et al. [189] also found that the addition of Ca chloride and $\mathrm{Ca}$ lactate could increase the HHV of solid product and decrease the pretreatment pressure in the HT treatment of loblolly pine. In any case, although the HT leads to some loss of volatile matters, the energy density is improved by the HT to some extent. In conclusion, the HT is an effective way of densifying the energy content independent on the feedstock. It can upgrade the quality of bio-waste by improving the dewaterability and the energy density of the products due to dehydration and decarboxylation.

Fig.5 An illustration of the upgrading of some typical and low rank coal. Data derived from these typical references: Liu et al.[46] Cocout and Eucalyptus leaves (holding time: 30 minutes), Mursito et al.[60] Indonesia tropical peat (holding time: 30 minutes), Sagakuchi et al.[184] Australia Loy Yang coal (holding time as 30 minutes: Brown coal-1 and 180 minutes: Brown coal-2), Yuliansyah et al.[106] Oil palm waste, such as Trunk and Frond (holding time: 30 minutes), Guo et al.[181] Victorian Loy Yang coal (holding time: 20 minutes), Lu et al.[66] Indonesia MSW, Chinese MSW and Japanese MSW at $220^{\circ} \mathrm{C}$ and 30 minutes, Hwang et al.[75] Paper, Dog food and Wood, Ge et al.[162] Japanese sewage sludge (holding time: 1, 30 minutes and 2, 45 minutes), Areeprasert et al.[161] Thailand paper sludge (holding time: 30 minutes) and Prawisudha et al.[62] Japanese MSW (holding time: 90 minutes).

\subsection{Dechlorination}

The previous section has discussed the effect of the HT on the dewatering performance and upgrading of these high moisture content bio-wastes such as the sewage sludge, paper sludge, and 
MSW. This section will mainly focus on the effect of the HT on the removal of the $\mathrm{Cl}$, which is known to promote clogging, corrosion, and serve as a $\mathrm{Cl}$ source for dioxin formation in a furnace. Therefore, dechlorination treatment is necessary for chemically recycling chlorinated waste. Current established $\mathrm{Cl}$ removal technologies are mostly focused on inorganic $\mathrm{Cl}$ removal by high temperature leaching [190] and chlorite ions elimination by reduced sulfur compounds [191, 192], and ferrous ions [193, 194], or by granular activated carbon, which focuses on the removal of organic $\mathrm{Cl}$ from water [195-197]; therefore, the use of other methods, such as hydrothermal treatment, is still promising to solve the $\mathrm{Cl}$ problem in plastic impregnated $\mathrm{MSW}[34,55,62,186]$.

Kubátová et al. [198] employed HT to dechlorinate aliphatic organics without catalyst or other additives. The dehydrohalogenation was reported to occur at temperature as low as $105-200{ }^{\circ} \mathrm{C}$ for 1,1,2,2-tetrachloroethane, lindane and dieldrin. Complete loss of the parent compounds was achieved in less than $1 \mathrm{~h}$ at 150,200 and $300{ }^{\circ} \mathrm{C}$ for 1,1,2,2-tetrachloroethane, lindane and dieldrin, respectively. The reaction of polyvinyl chloride (PVC) at $300{ }^{\circ} \mathrm{C}$ for $1 \mathrm{~h}$ was recorded to generate aromatic hydrocarbons ranging from benzene to anthracene and char residue with carbon-to-hydrogen molar ratio of $1: 1$. The $\mathrm{Cl}$ content of the residue was less than $1 \mathrm{wt} \%$, much smaller than that of the original polymer, which was $57 \mathrm{wt} . \%$. All compounds, including lindane, dieldrin, tetrachloroethane, trichloroethene, and PVC, were shown to yield chloride ion as the major product (at higher temperatures), indicating that complete dechlorination of some aliphatic organochlorines by the HT could be viable. Fig. 6 presents the $\mathrm{Cl}$ transformation of two kinds of chlorinated Japanese MSW during the HT process. It clearly indicates that the HT was effective to convert the organic $\mathrm{Cl}$ into inorganic $\mathrm{Cl}$. Results from Mikata et al. and Takeshita et al. [199, 200] also showed that the pyrolysis of polyvinyl chloride PVC in the range of $200-300{ }^{\circ} \mathrm{C}$ emitted $\mathrm{HCl}$ gas dissolving into water due to the dehydrochlorination, which is in accordance with that shown in Fig.6. At a condition of relative low temperature and short holding time, the $\mathrm{Cl}$ transformation from the organic (insoluble) to inorganic (soluble) was not so effective by the HT. A very limit conversion was observed at a HT condition of $234^{\circ} \mathrm{C}$ for 5 minutes, especially for the $\mathrm{Cl}$ in the form of PVC existing in wood [75]. A considerable quantity of organic $\mathrm{Cl}$ was converted into the inorganic one as the HT temperature or holding time is increased. Both the temperature and the holding time were significant for this conversion reaction as indicated by the result of " $210{ }^{\circ} \mathrm{C}$ and 90 minutes" and "225 ${ }^{\circ} \mathrm{C}$ and 30 minutes" in Fig.6. A longer holding time for MSW over $210{ }^{\circ} \mathrm{C}$ or a higher temperature for MSW over 90 minutes promoted the dehydrochlorination, enhancing the generation of soluble $\mathrm{Cl}$ compounds. Under a HT temperature of $295^{\circ} \mathrm{C}$ and pressure of $8 \mathrm{MPa}$, all the $\mathrm{Cl}$ in the form of PVC was converted into inorganic one within only 5 minutes [75].

Fig. 6 The $\mathrm{Cl}$ behavior during the HT process. Data adapted from ref.[62].

Most of the $\mathrm{Cl}$ will remain in the solid part with some shifting to liquid products (eg. bio-oil) regardless of the operating parameters. More than $85 \mathrm{wt} \%$ of $\mathrm{Cl}$ originating from $\mathrm{PVC}$ was reported to stay in the char independent of the conditions, which were " $234{ }^{\circ} \mathrm{C}$ and $3 \mathrm{MPa"}$ and "295 ${ }^{\circ} \mathrm{C}$ and $8 \mathrm{MPa}$ " [75]. However, most of the $\mathrm{Cl}$ atoms remained in char in the form of soluble compounds, indicating that dehydrochlorination played more important role in the $\mathrm{Cl}$ conversion. It could be attributed to: 1) the generation of $\mathrm{HCl}$ dissolved in moisture at the surface and in the pores of char particles; 2) the $\mathrm{Cl}$ atoms were chemically combined by alkali metals existing in char to produce 
salts [75, 201]. As above mentioned, the dechlorination process occurred readily and the hydrochloric acid as a water-soluble $\mathrm{Cl}$ species was generated during the HT process. Accordingly, the alkali or ammonia was usually added to promote the $\mathrm{Cl}$ transformation from the organic to inorganic [68, 202-207]. It is suggested that with an alkali additive, the hydrochloric acid produced because of the dechlorination in HT process reacted with alkali to produce inorganic salts, which can be easily removed from the solid phase by washing process [68].

In clean fuel production from straw, the water washing has been utilized to reduce the amount of $\mathrm{K}$ and $\mathrm{Cl}[208,209]$. Many studies on biomass or coal cleaning have shown that a large portion of the $\mathrm{Cl}$ could be released by water-washing [190, 210, 211]. About $90 \%$ of the $\mathrm{Cl}$ was released from biomass char within $20 \mathrm{~min}$ in this way [211]. Hwang et al. [212] reported that approximately 85 wt.\% of easily water-soluble $\mathrm{Cl}$ was leached out from MSW char after the first washing procedure. Akimoto et al. [203] reported that the organic chlorides in fuel oil could be dechlorinated by pure water above $100{ }^{\circ} \mathrm{C}$. Indrawan et al. [34] investigated effect of the washing parameters, including the ratio of water to sample, the mixing time, washing temperature and mixing intensity, on the $\mathrm{Cl}$ removal efficiency of HT pretreated MSW. Results show that the inorganic $\mathrm{Cl}$ removal efficiency was significantly enhanced with the ratio of water to sample and the washing temperature. Up to $96 \%$ of inorganic $\mathrm{Cl}$ was removed only by one time washing under a washing temperature of $40{ }^{\circ} \mathrm{C}$ with a water to sample ratio of $32: 1$, mixing 5 minutes with a mixing speed of $400 \mathrm{rpm}$. However, a huge amount of water was required in the water washing. It would be possible to save water consumption by reusing the washed water. Fig. 7 presents some experimental results relating to the water reuse times under three kinds of water to sample ratio. It clearly indicated more $\mathrm{Cl}$ could be removed by reusing the washed water, especially at a water to sample ratio of 1:1. The $\mathrm{Cl}$ removal efficiency of sample at water to sample ratio of 1:1 with one time reuse was higher than that of sample at water to sample ratio of 2:1 with one time washing. Therefore, it is feasible to save the water consumption by reusing the washed water in a commercial plant.

Fig.7 Feasibility of the water reuse during washing process. Data adapted from refs.[34, 68].

\subsection{Denitrification}

Nitrogen oxides $\left(\mathrm{NO}_{x}\right)$ are formed as a result of the thermal oxidation of biomass wastes with high $\mathrm{N}$ content. It is formed primarily in two ways: (1) high temperature thermal fixation of $\mathrm{N}$ in the combustion air with excess oxygen, producing thermal $\mathrm{NO}_{x}$; and (2) conversion of $\mathrm{N}_{2}$ that is chemically bound in the fuel, producing fuel $\mathrm{NO}_{x}$. The amount of $\mathrm{NO}_{x}$ formed depends on flame temperature, the fuel $\mathrm{N}$ content, quantity of excess air used for combustion, the degree of turbulence, and the residence time at high temperature. An increase in any of these factors results in increasing in $\mathrm{NO}_{x}$ formation. The $\mathrm{NO}_{x}$ contributes to a variety of environmental problems, including acid rain and acidification of aquatic systems, the greenhouse effect, photochemical smog, and visibility degradation [36-38]. As a result, the viability of applying new technologies to extract energy from biomass with high $\mathrm{N}$ content in the future [213], to a large extent, will be determined by the $\mathrm{NO}_{x}$ emissions properties [33].

Generally, the $\mathrm{NO}_{x}$ control technologies can be categorized as: (a) pre-combustion controls (physical fuel cleaning and fuel switching blending), (b) combustion controls (low NO, combustion, 
613 furnace sorbent injection, fuel or gas re-burning, decoupling combustion (DC, the complex 614 reactions during the combustion process are separated and reorganized to enhance the 615 beneficial interactions, thus inhibiting the undesired interactions), fluidized bed combustion 616 (FBC) and pressurized fluidized bed combustion (PFBC)), and (c) post-combustion controls 617 (selective catalytic reduction (SCR) and selective non-catalytic reduction (SNCR)). Intensive studies 618 on the $\mathrm{NO}_{x}$ emission and reduction during coal combustion have been carried out and air- and 619 fuel-staging technology, SCR, PFBC, the thermal DeNOx process and the DC were usually used to 620 reduce $\mathrm{NO}_{x}$ emissions [214-221]. The $\mathrm{DC}$ as a new low $\mathrm{NO}_{x}$ emission technology for coal was 621 originally developed in dual-bed model and then applied in circulating fluidized bed (CFB) 622 combustor $[215,220]$. It has been verified as an effective $\mathrm{NO}_{x}$ emission control technology for coal 623 combustion. Chen et al. [33] investigated the variability of applying DC to reduce NO emission from 624 the combustion of some typical industrial biomass wastes, such as mycelial waste and sewage sludge, 625 with high $\mathrm{N}$ content. The result implies that the $\mathrm{DC}$ was promising to reduce the NO emission. At a 626 combustion temperature of $1,073 \mathrm{~K}$, up to $40 \% \mathrm{NO}$ emission can be reduced. Moreover, the DC 627 shows a good stability for $\mathrm{NO}$ emission versus the total gas velocity and $\mathrm{O}_{2}$-fuel ratio at $1,073 \mathrm{~K}$ 628 compared to the conventional combustion. There are many excellent researches focusing on the fuel $629 \mathrm{~N}$ conversion, emission and controls. Interested reader can refer to these excellent works [222-228].

630 This section will mainly focus on the precombustion control by concentrating on the $\mathrm{N}$ behavior 631 during the HT. The word "denitrification" is used here to represent this N removal by the HT. Wang 632 and Wang [229] reported that the organic $\mathrm{N}$ primarily existed in the suspended solid part in the 633 sewage, accounting for about $94 \%$ of the total N. Denitrification increases with increasing the HT 634 temperature and the holding time because of the dissolution and the hydrolysis of the protein. 635 Correspondingly, both the total $\mathrm{N}$ and the organic $\mathrm{N}$ in the liquid was increased. Moreover, because 636 the hydrolysis of the protein generated polypeptide, dipeptide and aminorganic acid, which would be 637 further hydrolized to produce organic acid, ammonia and carbon dioxide [230]; the concentration of 638 the $\mathrm{NH}_{4}{ }^{+} \mathrm{N}$ was also improved with the holding time or the HT temperature. At $210{ }^{\circ} \mathrm{C}$ with 75 639 minutes, the dissolving ratio of suspended solids and protein reached $60.02 \%$ and $47.21 \%$, 640 respectively. This dissolution and hydrolysis of the protein/extracellular polymeric substances was 641 also the main reason that the HT pretreatment could improve the anaerobic digestion of sewage 642 sludge [166]. Fig. 8 shows the effect of the HT temperature on the N content in the solid product with 643 regard to some typical high moisture and $\mathrm{N}$ content bio-waste, such as the sewage sludge, paper 644 sludge and mycelial waste. As the temperature was lower than $220{ }^{\circ} \mathrm{C}$, the $\mathrm{N}$ contained in solid kept 645 decreasing with the temperature. However, when the temperature was too high (higher than $220^{\circ} \mathrm{C}$ ), 646 the $\mathrm{N}$ contained in solid would increase with the temperature for paper sludge. Similar results were 647 also observed in hydrothermal carbonization of wheat straw, poplar wood and olive oil residues at a 648 relative low temperature $\left(180-230{ }^{\circ} \mathrm{C}\right)$ but long holding time $(8 \mathrm{~h})$, where the $\mathrm{N}$ content is 649 significant increased with increasing the HT temperature [231]. This could be attributed to these two 650 main reasons: (1) some $\mathrm{N}$ was absorbed by the char or colloid generated in the HT process, (2) the 651 polymerization under severe reaction would reduce some carboxyl and hydroxyl groups, 652 correspondingly increasing the $\mathrm{N}$ relative content in the solid biofuel. It was reported that some of 653 the fragments formed from the degradation of biomacromolecules due to the HT were highly 
reactive. The unsaturated compounds, which were easily polymerized, were being created by the elimination of carboxyl and hydroxyl groups [123]. In the case of (highly reactive) lignin fragments, polymerization has been reported to be completed within several minutes above $300{ }^{\circ} \mathrm{C}[232,233]$. Falco et al. [234] stated that this co-condensation could be strengthened by increasing the amount of monosaccharide glucose when synthesized the nitrogen-doped carbon materials from the microalgae by the HT.

Fig.9 presents the distribution and mass balance of $\mathrm{N}$ (wt.\%) in mycelial waste under several HT conditions. It clearly indicated that the $\mathrm{N}$ in solid was dramatically reduced by the HT pretreatment, especially when the HT temperature was lower than $200{ }^{\circ} \mathrm{C}$. Zhang et al. [163] reported that over $45 \%$ of $\mathrm{N}$ in the raw antibolic mycelial waste was removed by the HT via the conversion of non-Kjeldahl organic $\mathrm{N}$ into Kjeldahl organic N. Akimoto et al. [203, 204] investigated the feasibility of water and aqueous solutions of metal salts and hydroxides for the denitrogenation of the fuel oil generated by the hydrothermal processing of municipal-waste-plastics under sub- and supercritical conditions. The $\mathrm{N}$ removed at around $25-250{ }^{\circ} \mathrm{C}$ was ascribed to the removal of $\mathrm{NH}_{4}^{+}$, benzonitrile, and $\varepsilon$-caprolactam through extraction by and/or the reaction with water. The hydrothermal denitrogenation of organic $\mathrm{N}$ compounds by pure water was reported to occur above $275{ }^{\circ} \mathrm{C}$ [203]. After replacing the pure water with the aqueous solutions of alkaline and alkaline earth metal salts and hydroxides, it shows the $\mathrm{pH}$ value of the aqueous solution plays a significant role in the HT removal of the organic $\mathrm{N}$. The $\mathrm{N}$ content was decreased markedly as increasing or decreasing the $\mathrm{pH}$ of the reaction condition, indicating the HT denitrogenation occurred readily under acidic or basic conditions [203]. Among the alkaline, alkaline earth metal compounds and the alkaline metal hydroxides, the last one was found to be the most effective for the hydrothermal denitrogenation. Moreover, more $\mathrm{N}$ could be removed with increasing the basicity of the alkaline metals. This is because water can act as a catalyst, a reactant and participates in the conversion of organic compounds at higher temperature. Its reactivity is often reinforced in the presence of acids, bases, or solid acid catalysts [7]. Therefore, it could be suggested the HT dechlorination mainly occurred through hydrolysis, whereas the HT denitrogenation occurred primarily via an ionic reaction path catalyzed by $\mathrm{OH}^{-}$ions in aqueous alkaline solutions.

Fig.8 Nitrogen content varying with the HT temperature. Data adapted from refs.[112, 161, 163, 229, 235].

In the case of some other detrimental elements, Reza et al. [236] converted corn stover, miscanthus, switch grass, and rice hulls with $\mathrm{HT}$ at 200,230 , and $260^{\circ} \mathrm{C}$ for $5 \mathrm{~min}$, in order to investigate the fate of inorganics during HT carbonization. The results show that the solid fuel yield was as low as $41 \%$ of the raw biomass, and decreased with increasing the HT temperature; while the HHV was improved up to $55 \%$. Moreover, all heavy metals were reduced by HT treatment; up to $90 \%$ of calcium, magnesium, sulfur, phosphorus, and potassium were removed with HT treatment, which was possibly due to hemicellulose removal. At a temperature of $260^{\circ} \mathrm{C}$, some structural $\mathrm{Si}$ was removed. The slagging and fouling indices are consequently reduced with HTC treatment relative to that of raw materials. The $\mathrm{Cl}$ content was reduced to a low slagging range after the HT temperature above $230{ }^{\circ} \mathrm{C}$, and Alkali index was medium for raw biomass but decreased by HT 
treatment. All these works suggested that the HT was a promising pretreatment technology to convert moist bio-wastes into clean solid biofuel without prior drying.

Fig.9 Distribution of nitrogen following the HT temperature. Data adapted from ref.[163]

\subsection{Coalification}

Fig.10 shows a Van Krevelen diagram [237] for the solid fuel production from some typical biomass and biomass wastes by the HT. The quality of solid fuels produced by the HT could be compared to the lignite or even sub-bituminous coal, depending on the reaction severity. Both the atomic ratio of $\mathrm{H} / \mathrm{C}$ and the $\mathrm{O} / \mathrm{C}$ kept decreasing with the $\mathrm{HT}$ temperature; yet, the degree is relevant to both the HT conditions and the material used. It has been reported that the char from lignin tends to have a lower hydrogen content [238] and char from cellulose tends to achieve a higher carbon content $[123,239]$. All the HT products exhibit lower $\mathrm{H} / \mathrm{C}$ and $\mathrm{O} / \mathrm{C}$ ratios than the initial materials, owing to the evolution of $\mathrm{H}_{2} \mathrm{O}$ and $\mathrm{CO}_{2}$ in the dehydration and decarboxylation reactions. Mass balance analyses indicated that carbonization of the feedstock retained a significant fraction of carbon in the solid char [112]. Due to the decrease in the number of low energy $\mathrm{H} / \mathrm{C}$ and $\mathrm{O} / \mathrm{C}$ bonds and increase of high energy $\mathrm{C}-\mathrm{C}$ bond, the energy density of biomass feedstock was improved, as discussed in section 4.1 .

Chemical dehydration significantly carbonizes biomass by lowering the $\mathrm{H} / \mathrm{C}$ and $\mathrm{O} / \mathrm{C}$ ratios [123]. According to the composition of the produced hydrochar from municipal wastes, Berge et al.[112] concluded that both the dehydration and decarboxylation occurred during carbonization, resulting in structures with high aromaticity. Previous studies indicated that the decomposition of the cellulose was mainly attributed to the dehydration according to reaction R1 as [123]:

$$
4\left(\mathrm{C}_{6} \mathrm{H}_{10} \mathrm{O}_{5}\right)_{n} \longleftrightarrow 2\left(\mathrm{C}_{12} \mathrm{H}_{10} \mathrm{O}_{5}\right)_{n}+10 \mathrm{H}_{2} \mathrm{O}
$$

The evolution of the $\mathrm{H} / \mathrm{C}$ and $\mathrm{O} / \mathrm{C}$ atomic ratios follows essentially the path of a dehydration process, similar to that previously observed for the hydrothermal transformation of saccharides such as glucose, sucrose or starch [127]. Significant decarboxylation only appeared after plenty of water has been generated [123]. There has been little effort to explain the fundamental chemistry, but these experimental results from the HT pretreatment of mycelial waste, paper sludge, kimchi, cellulose and sewage sludge also show that dehydration can be achieved without significant decarboxylation at low reaction severity (as indicated in Fig.10) [69, 125, 151, 161-163]. It is largely unknown to which extent biomass can be carbonized without major decarboxylation. However, the rate of dehydration was thought be much higher than decarboxylation during common hydrothermal carbonization [123].

Fig.10 Van Krevelen diagram for the solid fuel production from bio-wastes by the HT at different temperatures in comparison with other solid fuel. Data adapted from Ge et al. [162] Japanese sewage sludge (holding time: 30 minutes), Liu et al. [46] Cocout (holding time: 30 minutes), Mursito et al. [60] Indonesia tropical peat (holding time: 30 minutes), Zhang et al. [163] mycelial waste (holding time: 30 minutes), Areeprasert et al. [161] paper sludge (holding time: 30 minutes), Gao et al. [151] cellulose (holding time: 30 minutes), Wiedner et al. [231] wheat straw, poplar and olive oil residues 
(holding time: 8 h), Yuliansyah et al. [106] Oil palm waste-trunk and Frond (holding time: 30 minutes), Liu et al. [46] Cocout (holding time: 30 minutes), Kim et al. [69] Kimchi and paper

734 (holding time: about 30 minutes) and Berge et al. [112] MSW and anaerobic digested sludge 735 (holding time: about $50 \mathrm{~h}$ ).

736 Dehydration is generally explained by elimination of hydroxyl groups, while decarboxylation is decarboxylation reactions. They are two major reactions that can remove oxygen heteroatom in the form of $\mathrm{H}_{2} \mathrm{O}$ and $\mathrm{CO}_{2}$, respectively [146]. As for the source of water, the dehydroxylation and condensation reaction are also regarded as the possible paths. Early studies stated that the dehydroxylation of catechol was worked as a path for water formation during the cleavage of phenolic and alcohol groups above $150{ }^{\circ} \mathrm{C}$ and $200{ }^{\circ} \mathrm{C}$ respectively in the case of HT conversion lignin [123]. As for the $\mathrm{CO}_{2}$, it was reported that the carboxyl and carbonyl groups were rapidly degrade above $150{ }^{\circ} \mathrm{C}$, releasing $\mathrm{CO}_{2}$ and $\mathrm{CO}$, respectively. Early observations conclude that the HT decomposition of the formic acid, which is formed in significant amounts during the cellulose degradation, yielding primarily $\mathrm{CO}_{2}$ and $\mathrm{H}_{2} \mathrm{O}$, was one likely source for $\mathrm{CO}_{2}$ formation [240]. Other possible sources include the condensation reactions as well as the cleavage of molecular bonds. Due to destruction of colloidal structures, gas formation, less hydrophilic functional groups, and a lower viscosity of water, physical dewatering is enhanced significantly under hydrothermal conditions [166]. Some of these effects are reversible; the combined mechanical/thermal dewatering technology has therefore been developed and widely applied to dewater a range of biomaterials [241-246].

Fig.11 Dehydration of D-fructose to 5-hydroxymethyfurfural [247] and decarboxylation stearic acid to diesel products [248].

Many reaction mechanisms would contribute to this coalification during the HT, whereas more detailed reaction pathways and kinetics are largely unknown with the exception of the HT degradation of glucose. Funke and Ziegler [123] have summarized and discussed these possible chemical mechanisms occurring in the HT process. According to previous studies on hydrochar formation mechanisms [120,122, 129, 132, 156, 249-252], the carbonaceous particles can be obtained via three main reaction pathways: (1) direct solid-solid conversion of biomass materials (termed "char") undergoing devolatilization, condensation, dehydration and decarboxylation; (2) polymerization of dissolved intermediates degraded from the original biomass towards polyfurans; (3) carbonization via further inter-molecule (named "coke"). Briefly, carbohydrates bio-wastes were hydrolyzed to glucose or fructose which was converted to 5-hydroxymethylfurfural (HMF) via dehydration under the HT condition. The derived HMF was polymerized to primary particles followed by aggregation and carbonization via further intermolecular dehydration to form carbonaceous spheres (coke) [252]. The coke accumulated along with longer carbonization time while a part of the HMF was dissolved in the liquid phase. Simultaneously, amino acids derived from hydrolysis of proteins in bio-waste subsequently interacted with sugars to form N-containing ring compounds via Mailard reaction [250]. The brown color and characteristic odor of hydrochars were the evidences of Mailard reaction [156]. Based on the aforementioned pathways, mechanism for solid biofuel from bio-wastes with HT treatment is summarized in Fig.12. It should be mentioned that the pathways are proposed according to the HT conversion of pure carbohydrates, such as 
glucose, xylose, maltose, amylopectin, hemicellulose, cellulose and lignin. To approach the underlying chemistry occurring in the HT conversion of bio-waste, more works should be done focusing on the kinetics and process simulation. Moreover, for HT conversion of a specific bio-waste, the contribution of each pathway would be different and should be further investigated.

Most recently, Danso-Boateng et al. [188] reported that the decomposition kinetics of PSS and SF could be modeled by first order kinetics with Arrhenius law. The activation energy was 70 and $78 \mathrm{~kJ} / \mathrm{mol}$, and the pre-exponential factors were $4.0 \times 10^{6}$ and $1.5 \times 10^{7} \mathrm{~min}^{-1}$, for solid decomposition of PSS and SF, respectively. Reza et al. [253] investigated the reaction kinetics of hydrothermal carbonization of loblolly pine. They proposed and validated that both hemicellulose and cellulose decomposed in parallel first-order reactions. The activation energy was $30 \mathrm{~kJ} / \mathrm{mol}$ for hemicellulose and $73 \mathrm{~kJ} / \mathrm{mol}$ for cellulose. At a short holding time, they observed both the reaction and diffusion effect during the hydrothermal carbonization of loblolly pine. The activation energy of sludge was close to that of cellulose but much higher than that of hemicellulose. This was attributed to the difference existing in their component and composition.

Fig.12 schematic clean solid biofuel formation pathways in HT of bio-wastes

\section{Fuel combustion characteristics}

\subsection{Mono-combustion}

Ohki et al. [254] upgraded the Indonesian low-rank coal by employing the HT at $200-350{ }^{\circ} \mathrm{C}$ and studied the combustion characteristic of the hydrothermally treated coal with a thermogravimetric analysis (TGA). It was reported that the ignition temperature $\left(T_{i}\right)$ shifts to a high temperature; whereas the change of the temperature $\left(T_{m}\right)$, at which the maximum combustion rate occurs, is not remarkable. The combustion rate was largely improved, representing about 2-3 times higher than the untreated one. For the $T_{i}$ and combustion rate, similar results was observed in our study concentrating on the combustion characteristics of the hydrothermally treated sewage sludge at $200{ }^{\circ} \mathrm{C}$ for $30 \mathrm{~min}$ [255]. However, the results for the $T_{m}$ presents a little different, which relates to the heating rate of TGA. The difference of $T_{m}$ between the treated and untreated sludge was negligible when the TGA was operated under a slow heating rate lower than $30{ }^{\circ} \mathrm{C} / \mathrm{min}$; while the $T_{m}$ of the hydrothermally treated sludge (HTS) was about $9.3 \%$ lower than that of the raw sludge (RS) when the heating rate was 40 and $50{ }^{\circ} \mathrm{C} / \mathrm{min}$. The HT pretreatment has caused substantial changes in the TG and DTG profiles [126]. According to Parshetti et al., [126] all the combustion parameters, such as the $T_{i}, T_{m}$, and the burnout temperature $T_{f}$ detected based on the mass stability, keep increasing with increasing the HT temperature. The maximum weight loss rate keeps decreasing with increasing the HT temperature, which is opposite to our previous results, indicating the HT enhanced the devolatilization rate of sewage sludge [76]. The thermogravimetric analysis by He et al., [156] also showed that the DTG profile altered from a single peak for raw sludge to two peaks for solid biofuel. The combustion reaction was best fitted to the first order for both raw sludge and solid biofuel. The combustion of solid biofuel is expected to be easier and more stable than raw sludge because of lower activation energy and pre-exponential factor. However, the combustion of solid biofuel produced from PEFB at a low HT temperature $\left(<250{ }^{\circ} \mathrm{C}\right)$ takes place in two stages (devolatilization and combustion), whereas the hydrochar produced at $350{ }^{\circ} \mathrm{C}$ shows only one major 
combustion stage (combustion temperature ranging from 310 to $590{ }^{\circ} \mathrm{C}$ ) [126]. Lu et al. [66] explored the combustion characteristics of HT pretreated Japanese MSW, Indian MSW, and Chinese MSW by comparing with three standard samples such as rice, cellulose, and polypropylene through TGA. The results show that before HT, the combustion behavior was determined by the composition of MSW, whereas after HT, it was considerably affected by the intrinsic characteristics of the MSW—-both and its properties will control the combustion behaviors.

Indrawan et al. [68] investigated the choline transformation during the combustion of the HT pretreated MSW with/without water washing under 500, 700 and $900{ }^{\circ} \mathrm{C}$ and stated that the major part of the choline in the unwashed HT MSW was transferred to the ash portion; whereas it was mainly shifted to the exhaust gases portion for the washed HT pretreated MSW because of the removal of the inorganic choline by the water washing. It could be concluded that the organic $\mathrm{Cl}$ is mainly emitted in exhaust gases, while the inorganic part mainly shifted to the ash. To detect the effect of the combustion temperature on the shift of inorganic $\mathrm{Cl}$, thermal degradation of several alkali-chlorine salts, such as $\mathrm{KCl}, \mathrm{NaCl}$ and $\mathrm{CaCl}_{2}$, was conducted with TGA. The results indicated that the water washing could be avoided if the combustion temperature is higher than $800{ }^{\circ} \mathrm{C}$ because most of the inorganic $\mathrm{Cl}$ will go to the ash part. Therefore, the HT product can be utilized for co-combustion with low-rank coal or the combustion of briquetting products itself without water washing at a temperature below $800{ }^{\circ} \mathrm{C}$. However, a water washing is suggested to remove the inorganic $\mathrm{Cl}$ which will transfer to the exhaust gases at a temperature higher than $850{ }^{\circ} \mathrm{C}$.

Erlach et al. [256] employed HT carbonization to pretreat wood to produce a coal-like substance being suitable for entrained flow gasification. They found that the gasification of solid biofuel is more efficient than the gasification of wood, but the losses and auxiliary energy consumption of the HT process lead to a lower overall efficiency of the conversion from wood to clean syngas. The carbon capture rate was found to be $73 \%$ in the gasification of hydrochar, which is lower than that of direct wood gasification. This was attributed to the carbon loss associated with the gaseous and liquid byproducts in the HT process. Tremel et al. [257] stated that the pulverization of solid biofuel is found to be much less energy intensive compared to wood. In a following gasification experiment, they found that the carbon conversion of solid biofuel at a residence time of $1.0 \mathrm{~s}$ is higher than $84 \%$ at a temperature of $1000-1400{ }^{\circ} \mathrm{C}$. The results show that the HT pretreatment process has improved biomass properties like energy density, grindability and particle shape and could be utilized to produce a standardized fuel. The HT pretreatment was feasible to produce this new fuel for entrained flow gasification.

Limited information is known about the impact of HT pre-treatment on the pollutants emission characteristics during the combustion. In a recent study, we investigated the $\mathrm{NO}_{x}$ emission behavior of HT pretreated and untreated sewage sludge employing five combustion modes, including conventional combustion (CC), decoupling combustion (DC), separated combustion (SC) and air-staging combustion (AC) with two operating modes, at a temperature of $800{ }^{\circ} \mathrm{C}$ [76]. The result shows the amount of $\mathrm{NO}_{2}$ and $\mathrm{N}_{2} \mathrm{O}$ was usually lower than 8 ppm for all experiments; the main component of the $\mathrm{NO}_{x}$ is the NO. Fig.13 shows the NO emission from the raw sludge (RS) and HT sludge (HTS) for different combustion modes (AC-A and AC-B represents different operation conditions in the AC). It is evident that the NO emission from the HTS was lower than that from the 
RS independent on the combustion mode employed. This was more notable for the CC and AC-B, where the NO emission of the HTS was only $49.3 \%$ and $43.6 \%$ of that from the RS, respectively. The NO emission from HTS in DC, SC and AC-A were 96.9\%, 92.1\% and 56.2\%, respectively, of that from RS. Both DC and AC were effective to reduce NO emission from coal and/or biomass combustion [214, 215, 258-260]. Compared with the NO emission from RS in CC, it was reduced to $39.4 \%, 37.0 \%$ and $72.8 \%$, respectively, by employing DC, AC-A and AC-B in the current study. The result in DC was in accordance with that from Chen et al [33]. It was reported the NO reduction efficiency can reach $70.0 \%, 72.0 \%$, and $52.2 \%$, respectively, for mycelia waste, Chinese sewage sludge, and Thailand sewage sludge at a combustion temperature of $1173 \mathrm{~K}$ in their study. Moreover, they also stated that in the range of 873-1073 K, a high temperature favors the NO reduction for biomass wastes combustion in DC. Considering the difference in the initial fuel-N content of RS (6.6\% d.b.) and HTS (6.2\% d.b.), the NO reduction ratio $\mathrm{NO}_{\text {reduction }}$ by the HT pretreatment in $\mathrm{CC}, \mathrm{DC}, \mathrm{SC}, \mathrm{AC}-\mathrm{A}$ and $\mathrm{AC}-\mathrm{B}$ was $50.7 \%, 3.1 \%, 7.9 \%, 43.8 \%$ and $56.4 \%$, respectively.

Only considering the NO reduction efficiency of $\mathrm{HT}$ pretreatment and DC/AC-B, the HT pretreatment is less effective to reduce the NO emission. However, as illustrated in the introduction, the sludge dewatering was regarded as an essential step for sludge thermal utilization because the high moisture content was one of the main obstacles. The HT pretreatment has been widely accepted to be one of the most effective methods to improve the sludge dewaterability $[63,166,261]$. It was reported that the energy consumption for removing the water from sewage sludge by thermal pretreatment was only about $30 \%$ of that consumed in conventional drying process [52, 63]. Moreover, the treated sludge could be combusted to recover energy with a relative lower NO emission in a conventional combustion facility. No extra investment is required to construct a special incinerator or to modify combustors to prevent the possible secondary pollution resulting from the high moisture/ $\mathrm{N}$ content. Therefore, although the reduction ratio of the HT pretreatment was a little smaller than that of DC and AC, the HT pretreatment could still be a powerful method to lower NO emission from sludge combustion.

To investigate the reason for NO reduction by the HT pretreatment, the X-ray photoelectron spectroscopy (XPS), Fourier Transform Infrared (FTIR) and TGA were conducted to detect the nitrogen functional group in sludge with or without HT pretreatment. It shows the main functional group of nitrogen within sludge was the $\mathrm{N}-\mathrm{C}$ bond in amide or amine at a binding energy of around $400 \mathrm{eV}$ and the N-H bonds in ammonia or protonated amine at a binding energy of about $402 \mathrm{eV}$ \{Zhao, $2013 \# 2153$ \}. The TGA data indicated that the weight loss rate (combustion rate) of HTS was much higher than that of RS. The maximum combustion rate of HTS was around 1.3-2.3 times more than that of RS. Most of the organic matters in HTS have been volatilized over the temperature range of $170-300{ }^{\circ} \mathrm{C}$ at a heating rate of $20^{\circ} \mathrm{C} \cdot \mathrm{min}^{-1}$, whereas the corresponding temperature rage was $170-375{ }^{\circ} \mathrm{C}$ for RS. These results verified that the HT pretreatment has promoted the devolatilization properties of sludge and consequently increased the $\mathrm{NH}_{3}$ release rate in HTS combustion. Taking the previous results from Miyamae et al. [262] and Kamabara et al. [217] into account, Zhao et al. [76] stated that the main reason for HT reducing NO emission was that the HT has improved the $\mathrm{NH}_{3}$ release rate and amount, enhancing the reaction of $\mathrm{NO}$ with $\mathrm{NH}_{3}$ similar to 
the $\mathrm{DeNO}_{\mathrm{x}}$ or SNCR process according to the reaction R2 and R3 [36]. Moreover, because the amount of $\mathrm{N}_{2} \mathrm{O}$ was very small $(<8 \mathrm{ppm})$, the $\mathrm{R} 3$ was supposed to be the main reaction occurred in the HTS combustion [76].

$$
\begin{gathered}
\mathrm{NCO}+\mathrm{NO} \rightarrow \mathrm{N}_{2} \mathrm{O}+\mathrm{CO} \\
2 / 3 \mathrm{NH}_{3}+\mathrm{NO} \rightarrow 5 / 6 \mathrm{~N}_{2}+\mathrm{H}_{2} \mathrm{O}
\end{gathered}
$$

Fig. 13 Comparison of NO emission from RS and HTS for different combustion modes [76, 235]. RS: raw sludge; CC: conventional combustion; DC: decoupling combustion; SC: separated combustion;

AC: air-stage combustion

\subsection{Co-combustion}

To improve the stability and remove the pathogenic bacteria and odorous substances, the HT was utilized to pretreat sewage sludge to produce the CSWS (coal-sludge-water slurry). Park et al. [175] studied on the stability and dispersibility of this slurry fuel and reported that the HT pre-treatment of sewage sludge at $200{ }^{\circ} \mathrm{C}$ enhanced the coal slurry rheological properties, such as the stability and dispersibility; the viscosity and solid content of the CSWS remained the same after $72 \mathrm{~h}$ stability testing, whereas those of the coal-water decreased by ca. $1000 \mathrm{cP}$ and $3.3 \%$, respectively. It is anticipated that positive synergistic relationships would be achieved when combusting the HT products with coal. The HT conversion of high moisture content wastes by co-combustion with coal would be a viable waste disposal solution from the viewpoint of suppressing the environmental pollution as well as saving coal consumption. Several studies have been conducted to investigate the co-combustion characteristic of the HT pretreated products, such as MSW, and PEFB [54, 56, 66, 72, 126]. Parshetti et al. [126] conducted co-combustion of hydrochar in three different blending ratios of $5 \%, 10 \%$, and $20 \%$ with coal to detect the interactive effect of hydrochars obtained at various HT temperatures on combustion characteristics of low rank Indonesian coal. The combustion was characterized by only one stage with TGA profile regardless of the blending ratios and the HT temperature. For all samples, the $T_{i}$ of the blended fuels was reduced and followed the weighted percentage of hydrochar, thus exhibiting an addictive behavior. A higher blending ratio will lower $T_{i}$ resulting in a potential fire hazard, and the fuel may consequently get burnt ahead of a point where it is expected to. Therefore, in the co-combustion, attention should be paid to ensure that the reduction in $T_{i}$ is within the allowable range for the currently available facilities [56]. The $T_{f}$ of the blended fuels increased with increasing in the blending ratio [54, 56, 126]. Muthuraman et al. [54] first compared the co-combustion characteristics of Indian coal with wood and the HT pretreated Japanese MSW and stated that the devolatilization properties of coal could be improved by blending of both wood and MSW. The ignition temperature was significantly reduced by co-combustion of the HT pretreated MSW with coal. Moreover, this effect became more prominent with increasing the blending ratio of HT pretreated MSW resulting from its high volatile matter content. The results indicated that blending of HT pretreated MSW improves the reactivity of low reactive char combustibles leading to a reduction in unburnt carbon (UC). However, the co-combustion characteristics would not depend on the properties of the HT product, but also those of the fuel co-combusted with the HT products. 
In a subsequent study, Muthuraman et al. [56] investigated the co-combustion characteristics of the HT pretreated MSW with different rank coals, including Indian, Indonesian and Australian coals, 936 with a TGA at a temperature ranging from ambient to $700{ }^{\circ} \mathrm{C}$ under the heating rate of $10{ }^{\circ} \mathrm{C} \cdot \mathrm{min}^{-1}$, 937 aiming to find how the parameters, such as the heating value, volatiles and ash contents affect the

ignition characteristics. The results indicated that the blending of HT pretreated MSW improves devolatilization properties of coal. However, the co-combustion characteristics of HT pretreated MSW and coal blend cannot be predicted only from the pyrolytic and/or devolatilization phenomena because other factors, such as the coal quality, also play a significant role in co-combustion characteristics. If the fuel co-combusted has a very low volatile content and very high amount of fixed carbon, the ignition temperature would not be considerably affected by blending of HT pretreated MSW because higher activation energy was required to initiate combustion. In a drop tube reactor (DTR), Lu et al. [139] studied the co-combustion behaviour of HT pretreated MSW with three kinds of low rank coals, including peat, lignite and sub-bituminous coal, at a blending ratio of 20 wt.\%. The results indicated that the coal characteristics significantly affect the properties of gaseous emission and UC. Blending of HT pretreated MSW would exert negative effects on the CO oxidation during co-combustion with high volatile matter content coal. It also contributes to the NO reduction for coal with low fixed carbon content; the lower the fixed carbon content is, the more effective the introduction of HT pretreated MSW will be on the NO reduction. Jin et al. [72] stated the NO emission will be always reduced by co-combustion of HT pretreated MSW with coal, and for the $\mathrm{NO}_{x}$ precursors, the introduction of the HT pretreated MSW encourages the conversion of HCN to $\mathrm{NH}_{3}$. Long residence time (RT) would help reduce the NO emission, whereas the excess air ratio (ER) exerts little effect on the NO reduction [139]. Jin et al. [72] tested both the effect of blending ratio and combustion temperature on the combustion efficiency to verify to which extent coal can be replaced with the MSW in terms of gaseous emissions and UC in fly ash (FA) in a bubbling fluidized bed (BFB). At low blending ratio $(<20 \%)$, the $\mathrm{CO}$ emission of co-combustion was much lower than that of coal combustion. The high $\mathrm{CO}$ emission of coal combustion was attributed to its high ash content, which would form an ash layer surrounding the FC [19]. In the case of high ER, RT was also a dominant parameter for CO oxidation [139]. Due to a low S content of MSW, the $\mathrm{SO}_{2}$ emission of co-combustion of coal with HT pretreated MSW kept decreasing with the addition of HT pretreated MSW and also rising in combustion temperature. However, the $\mathrm{HCl}$ emission increased with the HT pretreated MSW percentage because of the high $\mathrm{Cl}$ content in MSW. In addition, the combustion efficiency was enhanced by adding the HT pretreated MSW so that the UC content decreased at the mixing ratio below 30\% at low temperature [139]. Thus, it is acceptable to substitute coal with $30 \%$ of HT pretreated MSW in a coal-fired combustor without major modification. The co-combustion of HT products with coal using currently facilities is a viable and cost-effective way to release the environmental protection stress and to achieve WTE.

\section{Energy Balance and Economic viability}

Namioka et al. [63] evaluated the energy consumption of solid fuel production from dewatered sewage sludge employing HT pretreatment by comparing with that of conventional thermal drying process. The proposed clean solid biofuel production process is composed of HT pretreatment, water removal by mechanical dewatering, concentration, and thermal drying. The assumption is that after 
HT, the moisture content of the sludge was reduced from $80 \mathrm{wt} \%$ to $50 \mathrm{wt} \%$ by pressure dewatering and then further decreased to $20 \mathrm{wt} . \%$ with a thermal drying; the separated liquid was first concentrated to $50 \mathrm{wt} . \%$ with a multi-effect evaporator and then dried to $20 \mathrm{wt} . \%$ with a procedure same as treating the solid parts. Moreover, the HT temperature was $200{ }^{\circ} \mathrm{C}$. Based on this assumption, the energy consumption of the proposed process was estimated to 2 thirds of that consumed in the conventional thermal drying. The result indicates that the HT pretreatment is an energy-saving process to control the sludge water content to produce solid biofuel. However, this estimation did not consider the thermal efficiency of all the facilities, solid recovery ratio, and energy density of products, etc., so that the reference value was weakened to some extent.

Prawisudha et al. [62, 186] employed the HT to produce solid biofuel from MSW in a commercial-scale plant and calculated the energy efficiency of the HT process to verify its self-sustainability in waste recycling. The capacity of this plant is $705 \mathrm{~kg} / \mathrm{h}$, running by steam with a temperature of $215^{\circ} \mathrm{C}$ and pressure of $2 \mathrm{MPa}$. During evaluating the energy efficiency of HT, the dry basis heating value of the raw MSW was assumed to be $100 \%$. The energy loss to the condenser and the water content in the product were also calculated based on the product's temperature. The heat loss was obtained from the difference in the total energy balance. The estimated result indicates that the energy required to treat MSW is approximately one-ninth $(11.3 \%)$ of the energy contained in MSW in this system. If it is assumed that all the energy was provided by combustion of the generated solid fuel, about $46.5 \%$ of the energy can be recovered by the HT. This implies that HT can utilize its own product as energy source to run the process and at the same time to produce net solid fuel products. Because these parameters come from a real plant, it is more meaningful for plant design. However, this calculation considers only the input and output of the HT process, but not including the other important parameters, such as the energy recovery ratio, dewatering performance, and solid recovery ratio, etc. Therefore, these results are not sufficient for the process optimization and large-scale commercialization. To achieve that, an overall estimate is necessary to take the effect of operating conditions on the carbon distribution, calorific value and recovery ratio of solid fuels, and the performance of mechanical dewatering and thermal drying into account.

Recently, a detailed energy and mass balance has been worked out for capacity of $1000 \mathrm{~kg} / \mathrm{batch}$ in sewage sludge [162]. This estimate considers the effect of the HT temperature and holding time on the mechanical dewatering performance, solid recovery ratio, and fuel properties of the solid product. The calculation is based on the schematic diagram shown in Fig.2. The thermal efficiency of the HT solid biofuel production is evaluated compared with the traditional sludge combustion technology - combination of thermal drying with combustion. Fig.14 presents a typical energy and mass balance of solid fuel production from dewatered sewage sludge by employing $\mathrm{HT}\left(200{ }^{\circ} \mathrm{C}\right.$ and 30 minutes). Under this condition, the solid recovery ratio was about $91 \mathrm{wt} \% \%$ and the dry basis heating value of the product is $19.8 \mathrm{MJ} / \mathrm{kg}$. Fig.14 shows that the energy required running this fuel production process was $1.3 \mathrm{MJ} / \mathrm{kg}$, whereas it is $3.2 \mathrm{MJ} / \mathrm{kg}$ for the conventional drying. The energy consumption of the HT solid fuel production process is only $40 \%$ of that consumed in conventional thermal drying. Zhao et al. [52] also reported that the energy consumption of solid fuel production by steam explosion was only $22 \%$ that of the conventional drying system to produce solid fuel from sewage sludge. The energy consumption of the current process was higher than that consumed in the 
1016 steam explosion. It is because that after mechanical dewatering, the residual water was assumed to

1017 be removed by forced thermal drying. In the real plant, the waste heat could be used as a heat source 1018 for the thermal drying as the drying performance has been improved by the HT pretreatment [180]. 1019 Then, the energy consumption could be further saved. Fig.14 also shows that the HT solid biofuel 1020 production process is an energy-self-sustainable system. About $52.4 \%$ of heat from fuel combustion 1021 was sufficient to support this process and another $47.6 \%$ can be recovered in terms of heat and 1022 electricity, etc. However, the thermal drying is an endothermic process, in which additional fuel is 1023 required to run the process. It indicated the high moisture (untreated) sewage sludge needs more heat 1024 for drying than it has available by combustion. The co-combustion of untreated sewage sludge with 1025 coal is not cost-effective.

1026 Fig.14 Energy balance of solid fuel production by HT pretreatment $\left(200{ }^{\circ} \mathrm{C}\right.$ for 30 minutes $)$

1027 In the case of PEFB in Malaysia, Stemann et al. [102] employed the HT to produce hydrochar and 1028 evaluated its economics. The investment, operating, and total production cost are calculated based on 1029 results from the simulation results from Aspen plus V7.1. Two different plant sizes were analyzed: 1030 one has a processing capacity of $5.7 \mathrm{t} / \mathrm{h}$ EFB while the other one has a processing capacity of 13.8 $1031 \mathrm{t} / \mathrm{h}$ EFB. The results show that the production cost is $19 \%$ lower for the bigger plant because of 1032 economy-of-scale effects. The biggest cost component by far are the carrying charges (including the 1033 total capital investment, collecting, taxes and insurances) (52-57\%), followed by transportation fee 1034 (15-18\%), maintenance costs (11-12\%), and cost of EFB (5-7\%). The total cost of the HT solid 1035 biofuel, including shipping from Malaysia to Europe, is about 7.94 and $9.67 € /$ GJ HHV for these two 1036 plants simulated. It is similar to the cost of industrial wood pellets, which is $114-140 € / \mathrm{t}$ between 10372007 and 2010 [263], corresponding to 6.54-7.96 €/GJ HHV. Compared with bituminous coal 1038 (about $2.6 € / \mathrm{GJ} \mathrm{HHV}$ ), these solid biofuel are not price-competitive. However, if considering 1039 environmental protection, sustainable development, and public policy incentives, such as carbon 1040 certificates, the solid biofuel production is still a cost-effective and promising way in the case of 1041 recycling EFB and releasing environmental stress. Moreover, because the cost of HT solid biofuel is 1042 in the same range as industrial wood pellets, their use for co-combustion will be economically viable 1043 under the same circumstances. For the economic evaluation, it remains large uncertainty with regard 1044 to HT performance and cost. Further optimization of the design and operating parameters based on a 1045 commercial plant is required and may well yield higher efficiencies and lower production costs.

\section{Conclusions}

1047 The conversion of waste biomass (bio-waste) into chemicals and energy can be used in order to 1048 protect our environment and achieve sustainable development. Hydrothermal (HT) treatment 1049 requires the application of heat and pressure to treat biomass in an aqueous medium. It is widely 1050 considered as a promising means for converting wet biomass into value-added products (such as 1051 biofuels and chemicals) because it obviates the need (capital, energy and time) for feedstock 1052 dewatering and drying. This work reviewed the clean solid biofuel production from bio-waste with 1053 high moisture, $\mathrm{N} / \mathrm{Cl}$ content. The results show that the HT processing is a cost-effective pretreatment. 1054 It offers many advantages including: 1) dewaterability can be largely improved and water can be 1055 removed cost-effectively; 2) the process does not require the addition and recovery of chemicals 
different from water; 3) simple and economical operation; 4) free of pathogens because of the high temperature. For these reasons, the HT processing can be considered an environmental friendly WTE process for high moisture content bio-wastes.

The main findings are summarized as followings:

(1) Some bio-wastes have high moisture, $\mathrm{N}$ and/or $\mathrm{Cl}$ content, low heating value, low energy density, and may be harmful to human beings, causing severe environmental and health-related issues. To dispose these bio-wastes safely and cost-effectively, it is necessary to pretreat or upgrade them prior to final utilization to homogenize different feedbacks into high value-added products;

(2) Hydrothermal (HT) pretreatment improves the hydrophobicity of a solid, thus enhancing the mechanical dewaterability of high moisture bio-wastes. As a result, the water, which is one of the main obstacles for bio-wastes utilization and disposal, can be easily and cost-effectively removed by a following mechanical (belt pressing, centrifugal, filtration, etc.) dewatering, which directly improves the gross heating value, thus decreasing the volume and increasing the quality of bio-wastes, which make it possible for fuel production. Therefore, HT can upgrade the quality of bio-wastes by improving the water removal ability and the energy density of the products;

(3) HT is effective to convert organic $\mathrm{Cl}$ into inorganic $\mathrm{Cl}$, thus reducing the potential for clogging, corrosion, and dioxin formation occurring in the combustion of bio-wastes with high $\mathrm{Cl}$ content. Moreover, during combustion of the solid biofuel production from high chlorine bio-wastes by HT, water washing process could be avoided when the combustion temperature is higher than $800^{\circ} \mathrm{C}$ because most of the inorganic $\mathrm{Cl}$ will go to the ash part;

(4) A small part of $\mathrm{N}$ can be removed by $\mathrm{HT}$ in terms of $\mathrm{NH}_{4}{ }^{+}$and water-soluble N. HT dechlorination and denitrogenation mainly occur through hydrolysis, whereas HT denitrogenation occurs primarily via an ionic reaction path catalyzed by $\mathrm{OH}^{-}$ions in aqueous alkaline solutions. Moreover, the HT pretreatment can result in largely reducing the $\mathrm{NO}_{\mathrm{x}}$ emission from solid biofuel combustion in current coal-fired facilities. The transformation of protein nature and reduction of the binding energy between chemical bonds, have improved the $\mathrm{NH}_{3}$ releasing rate and amount during combustion of solid biofuel, thus enhancing the reaction of $\mathrm{NO}$ with $\mathrm{NH}_{3}$ similar to the $\mathrm{DeNO}_{x}$ or SNCR process, which is identified as the main reason that the HT dramatically reduced the NO emission from solid biofuel combustion;

(5) The quality of solid fuels produced by the HT could be compared to the lignite or even sub-bituminous coal, depending on the reaction severity. Both the atomic ratio of $\mathrm{H} / \mathrm{C}$ and the $\mathrm{O} / \mathrm{C}$ kept decreasing with the HT temperature; yet, the degree is relevant to both the HT conditions and the material used. The evolution of the $\mathrm{H} / \mathrm{C}$ and $\mathrm{O} / \mathrm{C}$ atomic ratios follows essentially the path of a dehydration process, significant decarboxylation only occurs after plenty of water has been generated. Therefore, it would be feasible to increase the water ratio to enhance the carbonization to improve the fuel quality in HT.

(6) HT pretreatment improves the combustion or co-combustion performance in terms of ignition temperature, pollutants emission, combustion completeness, and reduction in unburnt carbon (UC). It was also found to encourage the conversion of $\mathrm{HCN}$ to $\mathrm{NH}_{3}$ in the solid biofuel combustion. In co-combustion, the final combustion performance of the blending fuels depends 
on the properties of HT solid fuel, the fuel co-combusted, and also the blending ratio. It is viable to substitute coal with $30 \%$ of HT solid biofuel (from MSW) in a coal-fired combustor without major modification.

(7) The energy consumption of the HT solid biofuel production process is about $40 \%$ of that consumed in conventional thermal drying. About half the energy from fuel combustion was sufficient to support this HT solid fuel production process and the rest can be recovered for heat and electricity, etc. Therefore, HT pretreatment for biofuels production from bio-wastes seems to have great potential, especially when considering uses of bio-wastes as alternative fuels in existing plants without significant modification.

\section{Future developments}

However, HT solid fuel production systems still face some challenges in real application [124]. Firstly, the corrosion, resulting from the yield of acid or alkali, reduces the life of reactor, thus increasing the cost, especially for catalytic HT in super-critical conditions; Secondly, it is necessary to treat the liquid from HT due to its high content of COD and undesirable elements; Thirdly, it is essential to recover heat (by heat exchangers) in order to reduce the operation cost, while it is difficult to realize; Fourthly, because of the good solid-liquid separation property of the HT product, its transportation was another barrier because of the potential blockage pipeline; Fifthly, the safety issue resulting from the operating pressure would increase the capital costs of reactor.

Therefore, more works focusing on these following aspects should be done in the near future:

$>$ There are technological barriers in the large-scale application of thermo-conversion processes. In order to overcome the technological limits and to develop a more economically competitive as well as environmentally sound technology, process scale up, pollutants reduction and cleaning bio-fuels production are subjects requiring additional research, investigation and study. For technical implementation of HT solid biofuel production and application, plans should base on a comprehensive management concept, which should address the feedstock properties and collection, treatment of by-products and recovery of nutrients. Any comparisons or modifications must consider the current substantial costs and environmental impacts of the alternative collection and treatment processes in use currently;

$>$ HT pre-treatment can improve the drying performance and shorten the sludge drying time. The mechanism is still unclear. Future works should concentrate on the impact of the HT pre-treatment on the water distribution, particle size distribution, porosity and rheological properties of sludge, and bound energy of the water, to explore this mechanism. Also, the effect of other operating parameters, such as the HT temperature, holding time, air temperature, velocity, humidity and sample thickness, on the drying behaviors will be studied to reveal how the HT pre-treatment affect the drying behaviors;

$>$ It is important to optimize the design and operation of HT from an overall viewpoint, which considering the solid fuel recovery ratio, energy density, treatment of by-products, and performance of mechanical dewatering and thermal drying, etc. An economic evaluation taking all aspects from feed handling to reactor design, heat recovery, environmental impacts, product separation, and auxiliary processes for by-product treatment into account should be done to 
1136 provide some theoretical basis for HT commercialization;

$1137>$ Even though a preliminary work indicated that the HT reducing NO emission could be ascribed to

1138 the reason that the HT has improved the $\mathrm{NH}_{3}$ release rate and amount, enhancing the reaction of

1139 NO with $\mathrm{NH}_{3}$ similar to the $\mathrm{DeNO}_{x}$ or SNCR process, the underlying chemistry involving in the

1140 combustion of HT solid biofuel combustion is still unclear. Due to the complexity and

1141 particularity of the bio-wastes, it is difficult to characterize and specify the reaction mechanism in

1142 its combustion. Therefore, the gaseous emission characteristics of solid biofuel derived from other

1143 kinds of bio-wastes should be further investigated to check if the HT pretreatment can always

1144 reduce the gaseous emission from bio-waste combustion. It is necessary to identify some model

1145 compounds to produce HT solid biofuel and investigate its combustion to fully understand the

1146 reaction mechanism of HT reducing gaseous pollutants. Furthermore, the impact of HT

1147 pretreatment on the transformation characteristics of trace metals and some undesirable elements

1148 should be investigate to utilize the solid biofuel in the real plant;

$1149>$ In the aspect of the co-combustion characteristics, the synergistic effect and reaction mechanisms

1150 should be investigated to improve combustion performance and optimize process design.

1151 Moreover, based on our experiences, the trace metals and heavy metals are mainly in the solid fuel.

1152 Therefore, the behavior of heavy metals during fuel combustion is one of the topics for further

1153 research.

\section{Acknowledgement}

1155 This work was financially supported by the State Scholarship Fund of China under Grant 1156 No.2011609050 and No.201206230168. This research work was also supported by Strategic 1157 China-Japan Cooperative Program on "Science and Technology (S\&T) for Environmental 1158 Conservation and Construction of a Society with Less Environmental Burden" of the National 1159 Nature Science Foundation of China and Japan Science and Technology Agency (No. 21161140329).

1160 All valuable comments and suggestions from editors and reviewers are thankful as well.

\section{References}

1162 [1] Saidur R, BoroumandJazi G, Mekhilef S, Mohammed H. A review on exergy analysis of biomass based fuels. Renew Sust Energ Rev. 2012;16:1217-22.

1164 [2] Shafiee S, Topal E. When will fossil fuel reserves be diminished? Energ Policy. 2009;37:181-9.

1165 [3] Dudley B. BP Global-Reports and publications. BP Statistical Review of World Energy 2012 and Historical data. http://www.bp.com/sectionbodycopy.do?categoryId=7500\&contentId=7068481.

[4] Siddiquee MN, Rohani S. Lipid extraction and biodiesel production from municipal sewage sludges: A review. Renew Sust Energ Rev. 2011;15:1067-72.

[5] Revellame E, Hernandez R, French W, Holmes W, Alley E. Biodiesel from activated sludge through in situ transesterification. J Chem Technol Biotechnol. 2010;85:614-20.

[6] Luterbacher JS, Fröling M, Vogel F, Maréchal F, Tester JW. Hydrothermal gasification of waste biomass: Process design and life cycle asessment. Environ Sci Technol. 2009;43:1578-83.

[7] Peterson AA, Vogel F, Lachance RP, Fröling M, Antal Jr MJ, Tester JW. Thermochemical biofuel production in hydrothermal media: a review of sub-and supercritical water technologies. Energ Environ Sci. 2008;1:32-65. 
1176

[8] Dincer I. Renewable energy and sustainable development: a crucial review. Renew Sust Energ Rev. 2000;4:157-75.

[9] Kaygusuz K. Renewable and sustainable energy use in Turkey: a review. Renew Sust Energ Rev. 2002;6:339-66.

[10] Omer AM. Energy, environment and sustainable development. Renew Sust Energ Rev. 2008;12:2265-300.

[11] Asif M, Muneer T. Energy supply, its demand and security issues for developed and emerging economies. Renew Sust Energ Rev. 2007;11:1388-413.

[12] Panwar N, Kaushik S, Kothari S. Role of renewable energy sources in environmental protection: A review. Renew Sust Energ Rev. 2011;15:1513-24.

[13] Bugaje I. Renewable energy for sustainable development in Africa: a review. Renew Sust Energ Rev. 2006;10:603-12.

[14] Chang J, Leung DY, Wu C, Yuan Z. A review on the energy production, consumption, and prospect of renewable energy in China. Renew Sust Energ Rev. 2003;7:453-68.

[15] Budzianowski WM. Sustainable biogas energy in Poland: Prospects and challenges. Renew Sust Energ Rev. 2012;16:342-9.

[16] Budzianowski WM. Opportunities for bioenergy in Poland: Biogas and biomass fuelled power plants. Rynek Energii. 2011;94:138-46.

[17] Budzianowski WM. Negative carbon intensity of renewable energy technologies involving biomass or carbon dioxide as inputs. Renew Sust Energ Rev. 2012;16:6507-21.

[18] Hensgen F, Richter F, Wachendorf M. Integrated generation of solid fuel and biogas from green cut material from landscape conservation and private households. Bioresour Technol. 2011;102:10441-50.

[19] Khan A, De Jong W, Jansens P, Spliethoff H. Biomass combustion in fluidized bed boilers: Potential problems and remedies. Fuel Process Technol. 2009;90:21-50.

[20] Demirbas A. Combustion characteristics of different biomass fuels. Prog Energ Combust. 2004;30:219-30.

[21] Haykırı-Açma H. Combustion characteristics of different biomass materials. Energ Convers Manage. 2003;44:155-62.

[22] Bergsma GC, Kampmann B, Croezen HJ. The battle for land between food, biofuels and nature. Proceedings of the 15th European Biomass Conference \& Exhibition. Berlin, Germany2007. p. 269-70.

[23] Hoogwijk M, Faaij A, van den Broek R, Berndes G, Gielen D, Turkenburg W. Exploration of the ranges of the global potential of biomass for energy. Biomass Bioenerg. 2003;25:119-33.

[24] Johansson DJ, Azar C. A scenario based analysis of land competition between food and bioenergy production in the US. Climatic Change. 2007;82:267-91.

[25] Shi Y, Ge Y, Chang J, Shao H, Tang Y. Garden waste biomass for renewable and sustainable energy production in China: Potential, challenges and development. Renew Sust Energ Rev. 2013;22:432-7.

[26] Menendez J, Inguanzo M, Pis J. Microwave-induced pyrolysis of sewage sludge. Water Res. 2002;36:3261-4.

[27] Domínguez A, Menéndez J, Inguanzo M, Pis J. Production of bio-fuels by high temperature pyrolysis of sewage sludge using conventional and microwave heating. Bioresour Technol. 
2006;97:1185-93.

[28] Martin MJ, Artola A, Balaguer MD, Rigola M. Activated carbons developed from surplus sewage sludge for the removal of dyes from dilute aqueous solutions. Chem Eng J. 2003;94:231-9.

[29] Dogru M, Midilli A, Howarth CR. Gasification of sewage sludge using a throated downdraft gasifier and uncertainty analysis. Fuel Process Technol. 2002;75:55-82.

[30] Shen L, Zhang DK. Low-temperature pyrolysis of sewage sludge and putrescible garbage for fuel oil production. Fuel. 2005;84:809-15.

[31] Shen L, Zhang DK. An experimental study of oil recovery from sewage sludge by low-temperature

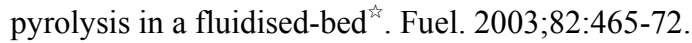

[32] Chen H, Wang Y, Xu G, Yoshikawa K. Fuel-N evolution during the pyrolysis of industrial biomass wastes with high nitrogen content. Energies. 2012;5:5418-38.

[33] Chen H, Zhao P, Wang Y, Xu G, Yoshikawa K. NO Emission Control during the Decoupling Combustion of Industrial Biomass Wastes with High Nitrogen Content. Energ Fuel. 2013;27:3186-93.

[34] Indrawan B, Prawisudha P, Yoshikawa K. Chlorine-free solid fuel production from municipal solid waste by hydrothermal process. J Japan Ins Energ. 2011;90:1177-82.

[35] Van Loo S, Koppejan J. The handbook of biomass combustion and co-firing: Earthscan; 2008.

[36] Winter $\mathrm{F}$, Wartha $\mathrm{C}$, Hofbauer $\mathrm{H}$. $\mathrm{NO}$ and $\mathrm{N}_{2} \mathrm{O}$ formation during the combustion of wood, straw, malt waste and peat. Bioresour Technol. 1999;70:39-49.

[37] Mukadi L, Guy C, Legros R. Prediction of gas emissions in an internally circulating fluidized bed combustor for treatment of industrial solid wastes. Fuel. 2000;79:1125-36.

[38] Tan LL, Li CZ. Formation of $\mathrm{NO}_{\mathrm{x}}$ and $\mathrm{SO}_{\mathrm{x}}$ precursors during the pyrolysis of coal and biomass. Part I. Effects of reactor configuration on the determined yields of $\mathrm{HCN}$ and $\mathrm{NH}_{3}$ during pyrolysis. Fuel. 2000;79:1883-9.

[39] Demirbas A. Potential applications of renewable energy sources, biomass combustion problems in boiler power systems and combustion related environmental issues. Prog Energ Combust. 2005;31:171-92.

[40] Obernberger I, Brunner T, Bärnthaler G. Chemical properties of solid biofuels-significance and impact. Biomass Bioenerg. 2006;30:973-82.

[41] Mckay G. Dioxin characterisation, formation and minimisation during municipal solid waste (MSW) incineration: review. Chem Eng J. 2002;86:343-68.

[42] Nordgren D, Hedman H, Padban N, Boström D, Öhman M. Ash transformations in pulverised fuel co-combustion of straw and woody biomass. Fuel Process Technol. 2013;105:52-8.

[43] Mroczek K, Kalisz S, Pronobis M, Sołtys J. The effect of halloysite additive on operation of boilers firing agricultural biomass. Fuel Process Technol. 2011;92:845-55.

[44] Teixeira P, Lopes H, Gulyurtlu I, Lapa N, Abelha P. Evaluation of slagging and fouling tendency during biomass co-firing with coal in a fluidized bed. Biomass Bioenerg. 2012;39:192-203.

[45] Cieplik M, Fryda L, van de Kamp W, Kiel J. Ash formation, slagging and fouling in biomass co-firing in pulverised-fuel boilers. Solid Biofuels for Energy: Springer; 2011. p. 197-217.

[46] Liu Z, Quek A, Hoekman SK, Balasubramanian R. Production of solid biochar fuel from waste biomass by hydrothermal carbonization. Fuel. 2013;103:943-9.

[47] Wang H, Nie Y. Municipal solid waste characteristics and management in China. J Air Waste Manage. 
2001;51:250-63.

[48] Zhang DQ, Tan SK, Gersberg RM. Municipal solid waste management in China: Status, problems and challenges. J Environ Manage. 2010;91:1623-33.

[49] Dong S, Kurt WT, Wu Y. Municipal solid waste management in China: using commercial management to solve a growing problem. Utilities Policy. 2001;10:7-11.

[50] Cheng H, Hu Y. Municipal solid waste (MSW) as a renewable source of energy: Current and future practices in China. Bioresour Technol. 2010;101:3816-24.

[51] Cheng H, Zhang Y, Meng A, Li Q. Municipal solid waste fueled power generation in China: a case study of waste-to-energy in Changchun city. Environ Sci Technol. 2007;41:7509-15.

[52] Zhao P, Ge S, Yoshikawa K. An orthogonal experimental study on Solid fuel production from sewage sludge by employing steam explosion. Appl Energy. 2013;112:1213-21.

[53] Namioka T, Morohashi Y, Yoshikawa K. Mechanisms of malodor reduction in dewatered sewage sludge by means of the hydrothermal torrefaction. J Environ Eng. 2011;6:119-30.

[54] Muthuraman M, Namioka T, Yoshikawa K. A comparison of co-combustion characteristics of coal with wood and hydrothermally treated municipal solid waste. Bioresour Technol. 2010;101:2477-82.

[55] Yamamoto T, Prawisudha P, Yoshikawa K. A research on chlorine removal from msw by hydrothermal treatment for solid fuel production. 4th Korea-Japan Joint Workshop Lake Yamanaka, Japan 2008.

[56] Muthuraman M, Namioka T, Yoshikawa K. Characteristics of co-combustion and kinetic study on hydrothermally treated municipal solid waste with different rank coals: A thermogravimetric analysis. Appl Energy. 2010;87:141-8.

[57] Wachendorf M, Richter F, Fricke T, Graß R, Neff R. Utilization of semi - natural grassland through integrated generation of solid fuel and biogas from biomass. I. Effects of hydrothermal conditioning and mechanical dehydration on mass flows of organic and mineral plant compounds, and nutrient balances. Grass Forage Sci. 2009;64:132-43.

[58] Richter F, Graß R, Fricke T, Zerr W, Wachendorf M. Utilization of semi - natural grassland through integrated generation of solid fuel and biogas from biomass. II. Effects of hydrothermal conditioning and mechanical dehydration on anaerobic digestion of press fluids. Grass Forage Sci. 2009;64:354-63.

[59] Richter F, Fricke T, Wachendorf M. Utilization of semi - natural grassland through integrated generation of solid fuel and biogas from biomass. III. Effects of hydrothermal conditioning and mechanical dehydration on solid fuel properties and on energy and greenhouse gas balances. Grass Forage Sci. 2010;65:185-99.

[60] Mursito AT, Hirajima T, Sasaki K. Upgrading and dewatering of raw tropical peat by hydrothermal treatment. Fuel. 2010;89:635-41.

[61] Hirashima T, Kobayashi H, Yukawa K, Tsunekawa M, Fukushima M, Sasaki K, et al. Fundamental study on the production of woody biomass fuel using hydrothermal treatment. J Min Mater Proc Inst Japan. 2003;119:118-24.

[62] Prawisudha P, Namioka T, Yoshikawa K. Coal alternative fuel production from municipal solid wastes employing hydrothermal treatment. Appl Energy. 2012;90:298-304.

[63] Namioka T, Morohashi Y, Yamane R, Yoshikawa K. Hydrothermal treatment of dewatered sewage sludge cake for solid fuel production. J Environ Eng. 2009;4:68-77. 
1302

[64] Nonaka M, Hirajima T, Sasaki K. Upgrading of low rank coal and woody biomass mixture by hydrothermal treatment. Fuel. 2011;90:2578-84.

[65] Nonaka M, Hirajima T, Kakizoe R, Sasaki K, Tsuchiya F, Tsurui M. Production of bio-coal fuel from low rank coal and woody biomass mixture by using a bench-scale continuous hydrothermal equipment. J Min Mater Proc Inst Japan. 2006;122:522-7.

[66] Lu L, Namioka T, Yoshikawa K. Effects of hydrothermal treatment on characteristics and combustion behaviors of municipal solid wastes. Appl Energy. 2011;88:3659-64.

[67] Yoshikawa K. Hydrothermal treatment of municipal solid waste to produce solid fuel. 7th International Energy Conversion Engineering Conference. Denver, Colorado: American Institute of Aeronautics and Astronautics; 2009.

[68] Indrawan B, Prawisudha P, Yoshikawa K. Combustion characteristics of chlorine-free solid fuel produced from municipal solid waste by hydrothermal processing. Energies. 2012;5:4446-61.

[69] Kim D, Prawisudha P, Yoshikawa K. Hydrothermal upgrading of korean msw for solid fuel production: Effect of msw composition. J Combust. 2012;2012:1-8.

[70] Prawisudha P, Namioka T, Yoshikawa K, Takano H, Ishida Y, Isoda H. Conversion of municipal solid waste into fuel for co-firing application with coal by hydrothermal treatment (part I: Chlorine removal). 2009 Symposium on Environmental Engineering Naha,Okinawa, Japan2009. p. 166-9.

[71] Prawisudha P, Yoshikawa K. Production of chlorine-free coal co-firing fuel from municipal solid waste by hydrothermal treatment. The 36th International Technical Conference on Clean Coal \& Fuel Systems - The Clearwater Clean Coal Conference Clearwater, Florida, USA2011. p. 839-48.

[72] Jin Y, Lu L, Ma X, Liu H, Chi Y, Yoshikawa K. Effects of blending hydrothermally treated municipal solid waste with coal on co-combustion characteristics in a lab-scale fluidized bed reactor. Appl Energy. 2013;102:563-70.

[73] Kim D, Yoshikawa K. Fuel production from mbt residue of korean msw employing hydrothermal treatment. TITech/IPE/KIMM Symposium 2010 Atami, Shizuoka, Japan2010.

[74] Kim D, Park KY, Kim HS, Yoshikawa K. Conversion of biomass in korean msw for fuel production and energy recovery by the hydrothermal treatment. The 1st IWWG-ARB Symposium. Hokkaido University, Japan2013.

[75] Hwang I-H, Aoyama H, Matsuto T, Nakagishi T, Matsuo T. Recovery of solid fuel from municipal solid waste by hydrothermal treatment using subcritical water. Waste Manage. 2012;32:410-6.

[76] Zhao P, Chen H, Ge S, Yoshikawa K. Effect of the hydrothermal pretreatment for the reduction of NO emission from sewage sludge combustion. Appl Energy. 2013;111:199-205.

[77] Rulkens W. Sewage sludge as a biomass resource for the production of energy: Overview and assessment of the various options $\dagger$. Energ Fuel. 2007;22:9-15.

[78] Lux Research. Water: Technologies turn waste to profit. 2009.

[79] Ronald J. Leblanc, Peter Matthews, Richard RP. Global atlas of excreta, wastewater sludge, and biosolids management: Moving forward the sustainable and welcome uses of a global resource: UN-HABITAT; 2009.

[80] Kelessidis A, Stasinakis AS. Comparative study of the methods used for treatment and final disposal of sewage sludge in European countries. Waste Manage. 2012;32:1186-95.

[81] Anne Gendebien, Environment Directorate-General. Environmental, economic and social impacts of the use of sewage sludge on land. 2010. 
1344

1345

1346

1347

1348

1349

1350

1351

1352

1353

1354

1355

1356

1357

1358

1359

1360

1361

1362

1363

1364

1365

1366

1367

1368

1369

1370

1371

1372

1373

1374

1375

1376

1377

1378

1379

1380

1381

1382

1383

1384

1385

[82] National Bureau of Statistics of China. Statistics data of Chinese sewage drainage. 2012.

[83] Dewil R, Baeyens J, Appels L. Enhancing the use of waste activated sludge as bio-fuel through selectively reducing its heavy metal content. J Hazard Mater. 2007;144:703-7.

[84] Jiang J, Du X, Yang S. Analysis of the combustion of sewage sludge-derived fuel by a thermogravimetric method in China. Waste Manage. 2010;30:1407-13.

[85] Bhattacharya S, Abdul Salam P, Runqing H, Somashekar H, Racelis D, Rathnasiri P, et al. An assessment of the potential for non-plantation biomass resources in selected Asian countries for 2010. Biomass Bioenerg. 2005;29:153-66.

[86] Li J, Hu R, Song Y, Shi J, Bhattacharya S, Abdul Salam P. Assessment of sustainable energy potential of non-plantation biomass resources in China. Biomass Bioenerg. 2005;29:167-77.

[87] Manara P, Zabaniotou A. Towards sewage sludge based biofuels via thermochemical conversion-a review. Renew Sust Energ Rev. 2012;16:2566-82.

[88] Moll S, Vrgoc M, Watson D, Femia A, Pedersen O, Villanueva A. Environmental Input-Output Analyses based on NAMEA data: A comparative European study on environmental pressures arising from consumption and production patterns. European Environment Agency, Copenhagen ETC/RWM working paper. 2007;2.

[89] United Nations-Department of Economic and Social Affairs. World Urbanization Prospects, the 2011 Revision. 2012.

[90] European Environment Agency. Municipal waste generation-outlook from OECD (Outlook 013)-Assessment published Jun 2007. 2007.

[91] Porteous A. Energy from waste incineration-a state of the art emissions review with an emphasis on public acceptability. Appl Energy. 2001;70:157-67.

[92] Anselmo Filho P, Badr O. Biomass resources for energy in North-Eastern Brazil. Appl Energy. 2004;77:51-67.

[93] Shaine Tyson K, Rymes M, Hammond E. Future potential for MSW energy development. Biomass Bioenerg. 1996;10:111-24.

[94] U.S. Environmental Protection Agency Office of Resource Conservation and Recovery. Municipal Solid Waste Generation, Recycling, and Disposal in the United States: Facts and Figures for 2010. 2011.

[95] Bank TW. Typical composition of MSW. 2012.

[96] Palm Oil Refiners Association of Malaysia. World Palm Oil Production. 2012.

[97] Kerdsuwan S, Laohalidanond K. Renewable energy from palm oil empty fruit bunch. In: Nayeripour DM, editor. Renewable Energy-Trends and Applications: InTech; 2011. p. 124-50.

[98] Yusoff S. Renewable energy from palm oil-innovation on effective utilization of waste. J Clean Prod. 2006;14:87-93.

[99] Geng A. Conversion of Oil Palm Empty Fruit Bunch to Biofuels. In: Zhen F, editor. Liquid, Gaseous and Solid Biofuels - Conversion Techniques2013. p. 479-90.

[100] Asia Biomass Energy Cooperation Promotion Office. Malaysia Promotes Utilization of Waste Biomass from Palm-Oil Industry. 2010.

[101] Abdullah N, Sulaiman F, Gerhauser H. Characterisation of oil palm empty fruit bunches for fuel application. J Phys Sci. 2011;22:1-24.

[102] Stemann J, Erlach B, Ziegler F. Hydrothermal Carbonisation of Empty Palm Oil Fruit Bunches: 
1386

Laboratory Trials, Plant Simulation, Carbon Avoidance, and Economic Feasibility. Waste and Biomass Valorization. 2012;3:1-14.

[103] Mohd Munzir H. The production of ecofiber from palm oil empty fruit bunch (EFB): Universiti Malaysia Pahang; 2008.

[104] Yuhazri M, Sihombing H, Umar N, Saijod L, Phongsakorn P. Solid Fuel from Empty Fruit Bunch Fiber and Waste Papers Part 1: Heat Released from Combustion Test. Global Engineers and Technologists Review. 2012;2:7-13.

[105] Jamari SS, Howse JR. The effect of the hydrothermal carbonization process on palm oil empty fruit bunch. Biomass Bioenerg. 2012;47:82-90.

[106] Yuliansyah AT, Hirajima T, Kumagai S, Sasaki K. Production of solid biofuel from agricultural wastes of the palm oil industry by hydrothermal treatment. Waste and Biomass Valorization. 2010;1:395-405.

[107] Demirbaş A. Biomass resource facilities and biomass conversion processing for fuels and chemicals. Energ Convers Manage. 2001;42:1357-78.

[108] Cantrell K, Ro K, Mahajan D, Anjom M, Hunt PG. Role of thermochemical conversion in livestock waste-to-energy treatments: obstacles and opportunities. Ind Eng Chem Res. 2007;46:8918-27.

[109] Ro K, Cantrell K, Hunt P, Ducey T, Vanotti M, Szogi A. Thermochemical conversion of livestock wastes: Carbonization of swine solids. Bioresour Technol. 2009;100:5466-71.

[110] Cao X, Ro KS, Chappell M, Li Y, Mao J. Chemical Structures of Swine-Manure Chars Produced under Different Carbonization Conditions Investigated by Advanced Solid-State 13C Nuclear Magnetic Resonance (NMR) Spectroscopy†. Energ Fuel. 2011;25:388-97.

[111] Xiu S, Shahbazi A, Shirley V, Cheng D. Hydrothermal pyrolysis of swine manure to bio-oil: effects of operating parameters on products yield and characterization of bio-oil. J Anal Appl Pyrol. 2010;88:73-9.

[112] Berge ND, Ro KS, Mao J, Flora JR, Chappell MA, Bae S. Hydrothermal carbonization of municipal waste streams. Environ Sci Technol. 2011;45:5696-703.

[113] Román S, Nabais J, Laginhas C, Ledesma B, González J. Hydrothermal carbonization as an effective way of densifying the energy content of biomass. Fuel Process Technol. 2012;103:78-83.

[114] Kruse A, Dinjus E. Hot compressed water as reaction medium and reactant: Properties and synthesis reactions. J Supercrit Fluids. 2007;39:362-80.

[115] Saidur R, Abdelaziz E, Demirbas A, Hossain M, Mekhilef S. A review on biomass as a fuel for boilers. Renew Sust Energ Rev. 2011;15:2262-89.

[116] Nussbaumer T. Combustion and co-combustion of biomass: fundamentals, technologies, and primary measures for emission reduction. Energ Fuel. 2003;17:1510-21.

[117] Duan P, Savage PE. Hydrothermal liquefaction of a microalga with heterogeneous catalysts. Ind Eng Chem Res. 2011;50:52-61.

[118] Duan P, Chang Z, Xu Y, Bai X, Wang F, Zhang L. Hydrothermal processing of duckweed: Effect of reaction conditions on product distribution and composition. Bioresour Technol. 2013;135:710-9.

[119] Liu Z, Zhang F-S, Wu J. Characterization and application of chars produced from pinewood pyrolysis and hydrothermal treatment. Fuel. 2010;89:510-4.

[120] Kang S, Li X, Fan J, Chang J. Characterization of Hydrochars Produced by Hydrothermal Carbonization of Lignin, Cellulose, d-Xylose, and Wood Meal. Ind Eng Chem Res. 2012;51:9023-31. 
1428

1429

1430

1431

1432

1433

1434

1435

1436

1437

1438

1439

1440

1441

1442

1443

1444

1445

1446

1447

1448

1449

1450

1451

1452

1453

1454

1455

1456

1457

1458

1459

1460

1461

1462

1463

1464

1465

1466

1467

1468

1469
[121] Titirici M-M, Antonietti M. Chemistry and materials options of sustainable carbon materials made by hydrothermal carbonization. Chem Soc Rev. 2010;39:103-16.

[122] Hu B, Wang K, Wu L, Yu SH, Antonietti M, Titirici MM. Engineering carbon materials from the hydrothermal carbonization process of biomass. Adv Mater. 2010;22:813-28.

[123] Funke A, Ziegler F. Hydrothermal carbonization of biomass: a summary and discussion of chemical mechanisms for process engineering. Biofuel Bioprod Bior. 2010;4:160-77.

[124] Libra JA, Ro KS, Kammann C, Funke A, Berge ND, Neubauer Y, et al. Hydrothermal carbonization of biomass residuals: a comparative review of the chemistry, processes and applications of wet and dry pyrolysis. Biofuels. 2011;2:71-106.

[125] Titirici M-M, Thomas A, Antonietti M. Back in the black: hydrothermal carbonization of plant material as an efficient chemical process to treat the $\mathrm{CO}_{2}$ problem? New J Chem. 2007;31:787-9.

[126] Parshetti GK, Hoekman SK, Balasubramanian R. Chemical, structural and combustion characteristics of carbonaceous products obtained by hydrothermal carbonization of palm empty fruit bunches. Bioresour Technol. 2013;135:683-9.

[127] Sevilla M, Fuertes AB. Chemical and structural properties of carbonaceous products obtained by hydrothermal carbonization of saccharides. Chem-eur J. 2009;15:4195-203.

[128] Titirici MM, Thomas A, Yu S-H, Müller J-O, Antonietti M. A direct synthesis of mesoporous carbons with bicontinuous pore morphology from crude plant material by hydrothermal carbonization. Chem Mater. 2007;19:4205-12.

[129] Falco C, Baccile N, Titirici M-M. Morphological and structural differences between glucose, cellulose and lignocellulosic biomass derived hydrothermal carbons. Green Chem. 2011;13:3273-81.

[130] Möller M, Nilges P, Harnisch F, Schröder U. Subcritical water as reaction environment: Fundamentals of hydrothermal biomass transformation. ChemSusChem. 2011;4:566-79.

[131] Kruse A, Badoux F, Grandl R, Wüst D. Hydrothermale Karbonisierung: 2. Kinetik der Biertreber-Umwandlung. Chem-Ing-Tech. 2012;84:509-12.

[132] Kruse A, Funke A, Titirici M-M. Hydrothermal conversion of biomass to fuels and energetic materials. Curr Opin Chem Biol. 2013;17:515-21.

[133] Sevilla M, Fuertes A. The production of carbon materials by hydrothermal carbonization of cellulose. Carbon. 2009;47:2281-9.

[134] Hoekman SK, Broch A, Robbins C. Hydrothermal carbonization (HTC) of lignocellulosic biomass. Energ Fuel. 2011;25:1802-10.

[135] Xiao L-P, Shi Z-J, Xu F, Sun R-C. Hydrothermal carbonization of lignocellulosic biomass. Bioresour Technol. 2012;118:618-23.

[136] Heilmann SM, Davis HT, Jader LR, Lefebvre PA, Sadowsky MJ, Schendel FJ, et al. Hydrothermal carbonization of microalgae. Biomass Bioenerg. 2010;34:875-82.

[137] Ross A, Biller P, Kubacki M, Li H, Lea-Langton A, Jones J. Hydrothermal processing of microalgae using alkali and organic acids. Fuel. 2010;89:2234-43.

[138] Mumme J, Eckervogt L, Pielert J, Diakité M, Rupp F, Kern J. Hydrothermal carbonization of anaerobically digested maize silage. Bioresour Technol. 2011;102:9255-60.

[139] Lu L. An investigation on co-combustion characteristics of hydrothermally treated municipal solid waste with coal in different kinds of combustors [Ph.D. thesis]: Tokyo Institute of Technology; 2013.

[140] Heilmann SM, Jader LR, Sadowsky MJ, Schendel FJ, von Keitz MG, Valentas KJ. Hydrothermal 
carbonization of distiller's grains. Biomass Bioenerg. 2011;35:2526-33.

[141] Oliveira I, Blöhse D, Ramke H-G. Hydrothermal Carbonization of Agricultural Residues. Bioresour Technol. 2013.

[142] Kang S, Li X, Fan J, Chang J. Solid fuel production by hydrothermal carbonization of black liquor. Bioresour Technol. 2012;110:715-8.

[143] Zhou D, Zhang L, Zhang S, Fu H, Chen J. Hydrothermal liquefaction of macroalgae Enteromorpha prolifera to bio-oil. Energ Fuel. 2010;24:4054-61.

[144] Karagöz S, Bhaskar T, Muto A, Sakata Y. Comparative studies of oil compositions produced from sawdust, rice husk, lignin and cellulose by hydrothermal treatment. Fuel. 2005;84:875-84.

[145] Goudriaan F, Peferoen D. Liquid fuels from biomass via a hydrothermal process. Chem Eng Sci. 1990;45:2729-34.

[146] Akhtar J, Amin NAS. A review on process conditions for optimum bio-oil yield in hydrothermal liquefaction of biomass. Renew Sust Energ Rev. 2011;15:1615-24.

[147] Yin S, Dolan R, Harris M, Tan Z. Subcritical hydrothermal liquefaction of cattle manure to bio-oil: effects of conversion parameters on bio-oil yield and characterization of bio-oil. Bioresour Technol. 2010;101:3657-64.

[148] Demirbas A. Competitive liquid biofuels from biomass. Appl Energy. 2011;88:17-28.

[149] Meyer S, Glaser B, Quicker P. Technical, economical, and climate-related aspects of biochar production technologies: a literature review. Environ Sci Technol. 2011;45:9473-83.

[150] Zhang L, Champagne P, Xu C. Bio-crude production from secondary pulp/paper-mill sludge and waste newspaper via co-liquefaction in hot-compressed water. Energy. 2011;36:2142-50.

[151] Gao Y, Wang X-H, Yang H-P, Chen H-P. Characterization of products from hydrothermal treatments of cellulose. Energy. 2012;42:457-65.

[152] Demir-Cakan R, Baccile N, Antonietti M, Titirici M-M. Carboxylate-rich carbonaceous materials via one-step hydrothermal carbonization of glucose in the presence of acrylic acid. Chem Mater. 2009;21:484-90.

[153] Toor SS, Rosendahl L, Rudolf A. Hydrothermal liquefaction of biomass: A review of subcritical water technologies. Energy. 2011;36:2328-42.

[154] Jin F, Zhou Z, Moriya T, Kishida H, Higashijima H, Enomoto H. Controlling hydrothermal reaction pathways to improve acetic acid production from carbohydrate biomass. Environ Sci Technol. 2005;39:1893-902.

[155] Goto M, Obuchi R, Hirose T, Sakaki T, Shibata M. Hydrothermal conversion of municipal organic waste into resources. Bioresour Technol. 2004;93:279-84.

[156] He C, Giannis A, Wang J-Y. Conversion of sewage sludge to clean solid fuel using hydrothermal carbonization: Hydrochar fuel characteristics and combustion behavior. Appl Energy. 2013;111:257-66.

[157] Jiang J, Du X. Study on part drying and briquetting of sewage sludge as fuel. The 6th Ministers' Forum on Infrastructure Development in the Asia-Pacific Region and the 2nd International Conference for China Urban Water Development. Beijing: China City Press; 2007. p. 489-97.

[158] Ge S, Zhao P, Li Y, Yan W, Chen Z. The combustion characteristics of sewage sludge-straw derived fuel. Proc CSEE. 2012;32:110-6.

[159] Zhao P, Ge S, Zhang C, Li Y, Yan W, Chen Z. Pilot process and combustion characteristics of 
sludge-straw derived solid biofuel. Trans CSAE. 2012;28:165-70.

[160] Zhao P, Ge S, Yoshikawa K. Solid fuel production from sewage sludge by employing steam explosion. 2012 International Conference on Applied Energy. Suzhou, China2012. p. 3179-85.

[161] Areeprasert C, Zhao P, Ma D, Yoshikawa K. Lab-scale and pilot-scale tests on solid fuel production from paper sludge employing hydrothermal treatment. The 5th International Conference on Applied Energy. Pretoria, South Africa: Elsevier; 2013. p. ID. ICAE2013-477.

[162] Ge S, Zhao P, Areeprasert C, Yoshikawa K. Evaluation of energy recycling from sewage sludge by producing solid fuel with hydrothermal treatment. The 5th International Conference on Applied Energy. Pretoria, South Africa2013. p. ID. ICAE2013-127.

[163] Zhang G, Ma D, Peng C, Xu G. Hydrothermal treatment of antibiotic mycelial dregs for solid bio-fuel preparation. CIESC Journal. 2013;64:3471-9.

[164] Tsang KR, Vesilind PA. Moisture Distribution in Sludges. Water Sci Technol. 1990;22:135-42.

[165] Lee DJ, Hsu YH. Measurement of bound water in sludges-A comparative study. Water Environ Res. 1995;67:310-7.

[166] Neyens E, Baeyens J. A review of thermal sludge pre-treatment processes to improve dewaterability. J Hazard Mater. 2003;98:51-67.

[167] Fisher W, Swanwick J. High-temperature treatment of sewage sludges. Water pollution control. 1971;70:355-73.

[168] Jiang ZL, Meng DW, Mu HY, Yoshikawa K. Study on the hydrothermal drying technology of sewage sludge. Sci China Technol Sci. 2010;53:160-3.

[169] Ge J, Ge S, Zhao P. Properties of dewatered sludge thermal conditioning. Chinese J Environ Eng. 2012;4:058.

[170] Saveyn H, Curvers D, Schoutteten M, Krott E, Van Der Meeren P. Improved dewatering by hydrothermal conversion of sludge. J Residuals Sci Tech. 2009;6:51-6.

[171] Liu X, Wang W, Gao X, Zhou Y, Shen R. Effect of thermal pretreatment on the physical and chemical properties of municipal biomass waste. Waste Manage. 2012;32:249-55.

[172] Bougrier C, Delgenès JP, Carrère H. Effects of thermal treatments on five different waste activated sludge samples solubilisation, physical properties and anaerobic digestion. Chem Eng J. 2008;139:236-44.

[173] Zhao P, Ge S, Ge J, Chen Z. A study on the improvement of sludge dewaterability by thermal conditioning. 2011 International Conference on Electric Technology and Civil Engineering (ICETCE): IEEE; 2011. p. 3838-41.

[174] Xun R, Wang W, Qiao W. Water distribution and dewatering performance of the hydrothermal conditioned sludge. Huan Jing Ke Xue. 2009;30:851-6.

[175] Park S-J, Bae J-S, Lee D-W, Ra HW, Hong J-C, Choi Y-C. Effects of Hydrothermally Pretreated Sewage Sludge on the Stability and Dispersibilty of Slurry Fuel Using Pulverized Coal. Energ Fuel. 2011;25:3934-9.

[176] Neyens E, Baeyens J, Dewil R. Advanced sludge treatment affects extracellular polymeric substances to improve activated sludge dewatering. J Hazard Mater. 2004;106:83-92.

[177] Sereewatthanawut I, Prapintip S, Watchiraruji K, Goto M, Sasaki M, Shotipruk A. Extraction of protein and amino acids from deoiled rice bran by subcritical water hydrolysis. Bioresour Technol. 2008;99:555-61. 
1554

1555

1556

1557

1558

1559

1560

1561

1562

1563

1564

1565

1566

1567

1568

1569

1570

1571

1572

1573

1574

1575

1576

1577

1578

1579

1580

1581

1582

1583

1584

1585

1586

1587

1588

1589

1590

1591

1592

1593

1594

1595

[178] Weil JR, Sarikaya A, Rau S-L, Goetz J, Ladisch CM, Brewer M, et al. Pretreatment of corn fiber by pressure cooking in water. Appl Biochem Biotech. 1998;73:1-17.

[179] Zhao P, Ge S, Areeprasert C, Ma D, Yoshikawa K. Study on the modeling of the drying kinetics of the hydrothermally treated paper sludge. Korea-Japan-China Joint Symposium. Jeju, Korea2012.

[180] Zhao P, Ge S, Areeprasert C, Ma D, Yoshikawa K. Effect of the hydrothermal pretreatment on the convective drying of paper sludge. ACS Sustainable Chemistry \& Engineering. 2013:DOI: $10.1021 / \mathrm{sc} 4003505$.

[181] Guo J, Tiu C, Hodges S, Uhlherr P. Hydrothermal-mechanical upgrading of brown coal. Coal Perparation. 1999;21:35-52.

[182] Yu Y, Liu J, Wang R, Zhou J, Cen K. Effect of hydrothermal dewatering on the slurryability of brown coals. Energ Convers Manage. 2012;57:8-12.

[183] Favas G, Jackson WR. Hydrothermal dewatering of lower rank coals. 2. Effects of coal characteristics for a range of Australian and international coals. Fuel. 2003;82:59-69.

[184] Sakaguchi M, Laursen K, Nakagawa H, Miura K. Hydrothermal upgrading of Loy Yang Brown coal-Effect of upgrading conditions on the characteristics of the products. Fuel Process Technol. 2008;89:391-6.

[185] McKendry P. Energy production from biomass (part 1): overview of biomass. Bioresour Technol. 2002;83:37-46.

[186] Prawisudha P, Novianti S. Municipal Solid Waste Treatment Using Hydrothermal Process to Produce a Renewable Energy Source. Inovasi. 2011;19:15-22.

[187] Reza MT, Lynam JG, Vasquez VR, Coronella CJ. Pelletization of biochar from hydrothermally carbonized wood. Environ Prog Sustain. 2012;31:225-34.

[188] Danso-Boateng E, Holdich R, Shama G, Wheatley A, Sohail M, Martin S. Kinetics of faecal biomass hydrothermal carbonisation for hydrochar production. Appl Energy. 2013;111:351-7.

[189] Lynam JG, Toufiq Reza M, Vasquez VR, Coronella CJ. Effect of salt addition on hydrothermal carbonization of lignocellulosic biomass. Fuel. 2012;99:271-3.

[190] Chen HL, Pagano M. The removal of chlorine from Illinois coal by high temperature leaching. Fuel Process Technol. 1986;13:261-9.

[191] Gordon G, Slootmaekers B, Tachiyashiki S, Wood III DW. Minimizing chlorite ion and chlorate ion in water treated with chlorine dioxide. J Am Water Works Assoc. 1990:160-5.

[192] Griese MH, Hauser K, Berkemeier M, Gordon G. Using reducing agents to eliminate chlorine dioxide and chlorite ion residuals in drinking water. J Am Water Works Ass. 1991;83:56-61.

[193] Griese MH, Kaczur JJ, Gordon G. Combining methods for the reduction of oxychlorine residuals in drinking water. J Am Water Works Ass. 1992;84:69-77.

[194] Iatrou A, Knocke WR. Removing chlorite by the addition of ferrous iron. J Am Water Works Ass. 1992;84:63-8.

[195] Dixon KL, Lee RG. The effect of sulfur-based reducing agents and GAC filtration on chlorine dioxide by-products. J Am Water Works Ass. 1991;83:48-55.

[196] Katz A, Narkis N. Removal of chlorine dioxide disinfection by-products by ferrous salts. Water Res. 2001;35:101-8.

[197] Siemens Water Technology. Organic chemicals removal from industrial process wate. 2010.

[198] Kubátová A, Lagadec AJ, Hawthorne SB. Dechlorination of lindane, dieldrin, tetrachloroethane, 
trichloroethene, and PVC in subcritical water. Environ Sci Technol. 2002;36:1337-43.

[199] Mikata N, Hashimoto, Takeuchi T, Nishiyama H. Research in thermal decomposition characterisitics of plastic waste. Nippon Steel Technical Report. 1996;360:38-45.

[200] Takeshita Y, Kato K, Takahashi K, Sato Y, Nishi S. Basic study on treatment of waste polyvinyl chloride plastics by hydrothermal decomposition in subcritical and supercritical regions. J Supercrit Fluids. 2004;31:185-93.

[201] Prawisudha P, Namioka T, Liang L, Yoshikawa K. Dechlorination behavior of mixed plastic waste by employing hydrothermal process and limestone additive. J Environ Sci Eng. 2011;5:432-9.

[202] Lv B, Zhao G, Li D, Liang C. Dechlorination and oxidation for waste poly (vinylidene chloride) by hydrothermal catalytic oxidation on Pd/AC catalyst. Polym Degrad Stabil. 2009;94:1047-52.

[203] Akimoto M, Ninomiya K, Takami S, Ishikawa M, Sato M, Washio K. Hydrothermal dechlorination and denitrogenation of municipal-waste-plastics-derived fuel oil under sub-and supercritical conditions. Ind Eng Chem Res. 2002;41:5393-400.

[204] Akimoto M, Sato T, Nagasawa T. Hydrothermal denitrogenation of fuel oil derived from municipal waste plastics in a continuous packed-bed reactor. Ind Eng Chem Res. 2003;42:2074-80.

[205] Yamasaki Y, Enomoto H, Yamasaki N, Nakahara M. NMR Study of Hydrothermal Reactions of Dichloromethane with and without Alkali. B Chem Soc Jpn. 2000;73:2687-93.

[206] Akimoto M, Iida T, Sato S. Hydrothermal Dechlorination of a Reclaimed Oil in a Continuous Packed-Bed Reactor. J Chem Eng Jpn. 2007;40:874-8.

[207] Hashimoto K, Suga S, Wakayama Y, Funazukuri T. Hydrothermal dechlorination of PVC in the presence of ammonia. J Mater Sci. 2008;43:2457-62.

[208] Jenkins B, Bakker R, Wei J. On the properties of washed straw. Biomass Bioenerg. 1996;10:177-200.

[209] Knudsen NO, Jensen PA, Sander B, Dam-Johansen K. Possibilities and evaluation of straw pretreatment. Tenth European Conference and Technology Exhibition. Wurzburg, Germany 1998. p. 224.

[210] Jenkins B, Baxter L, Miles Jr T, Miles T. Combustion properties of biomass. Fuel Process Technol. 1998;54:17-46.

[211] Jensen PA, Sander B, Dam-Johansen K. Removal of K and Cl by leaching of straw char. Biomass Bioenerg. 2001;20:447-57.

[212] Hwang I, Matsuto T, Tanaka N. Water-soluble characteristics of chlorine in char derived from municipal solid wastes. Waste Manage. 2006;26:571-9.

[213] Xie Z, Feng J, Zhao W, Xie KC, Pratt KC, Li CZ. Formation of NOx and SOx precursors during the pyrolysis of coal and biomass. Part IV. Pyrolysis of a set of Australian and Chinese coals. Fuel. 2001;80:2131-8.

[214] Dong L, Gao S, Song W, Li J, Xu G. NO reduction in decoupling combustion of biomass and biomass-coal blend. Energ Fuel. 2008;23:224-8.

[215] He J, Song W, Gao S, Dong L, Barz M, Li J, et al. Experimental study of the reduction mechanisms of NO emission in decoupling combustion of coal. Fuel Process Technol. 2006;87:803-10.

[216] Kasuya F, Glarborg P, Johnsson JE, Dam-Johansen K. The thermal $\mathrm{DeNO}_{\mathrm{x}}$ process: Influence of partial pressures and temperature. Chem Eng Sci. 1995;50:1455-66.

[217] Kambara S, Takarada T, Toyoshima M, Kato K. Relation between functional forms of coal nitrogen 
and NOx emissions from pulverized coal combustion. Fuel. 1995;74:1247-53.

[218] Lu Y, Jahkola A, Hippinen I, Jalovaara J. The emissions and control of $\mathrm{NO}_{\mathrm{x}}$ and $\mathrm{N}_{2} \mathrm{O}$ in pressurized fluidized bed combustion. Fuel. 1992;71:693-9.

[219] Hämäläinen JP, Aho MJ. Conversion of fuel nitrogen through $\mathrm{HCN}$ and $\mathrm{NH}_{3}$ to nitrogen oxides at elevated pressure. Fuel. 1996;75:1377-86.

[220] Yang X, Chen A, Xie J, Ding T, Song W, Lin W, et al. Emissions of NO and $\mathrm{N}_{2} \mathrm{O}$ in a decoupled circulating fluidized bed combustor during coal and biomass co-firing. Proceedings of International Symposium on EcoTopia Science 2007, ISET07. Nagoya, Japan2007.

[221] Cai L, Shang X, Gao S, Wang Y, Dong L, Xu G. Low-NO $\mathrm{NO}_{x}$ coal combustion via combining decoupling combustion and gas reburning. Fuel. 2011:doi:10.1016/j.fuel.2011.12.028.

[222] Glarborg P, Jensen A, Johnsson JE. Fuel nitrogen conversion in solid fuel fired systems. Prog Energ Combust. 2003;29:89-113.

[223] Molina A, Eddings E, Pershing D, Sarofim A. Char nitrogen conversion: implications to emissions from coal-fired utility boilers. Prog Energ Combust. 2000;26:507-31.

[224] Skalska K, Miller JS, Ledakowicz S. Trends in NOx abatement: A review. Sci Total Environ. 2010;408:3976-89.

[225] Correa SM. A review of NOx formation under gas-turbine combustion conditions. Combust Sci Technol. 1993;87:329-62.

[226] Normann F, Andersson K, Leckner B, Johnsson F. Emission control of nitrogen oxides in the oxy-fuel process. Prog Energ Combust. 2009;35:385-97.

[227] Hayhurst A, Lawrence A. Emissions of nitrous oxide from combustion sources. Prog Energ Combust. 1992;18:529-52.

[228] Smoot L, Hill S, Xu H. NOx control through reburning. Prog Energ Combust. 1998;24:385-408.

[229] Wang Z, Wang W. Thermal hydrolysis test of surplus sludge. China Environ Sci. 2005;25:56-60.

[230] Shanableh A, Jomaa S. Production and transformation of volatile fatty acids from sludge subjected to hydrothermal treatment. Water Sci Technol. 2001:129-35.

[231] Wiedner K, Naisse C, Rumpel C, Pozzi A, Wieczorek P, Glaser B. Chemical modification of biomass residues during hydrothermal carbonization-What makes the difference, temperature or feedstock? Org Geochem. 2013;54:91-100.

[232] Aronovsky S, Gortner R. The cooking process -I role of water in the cooking of wood. Ind Eng Chem. 1930;22:264-74.

[233] Masselter S, Zemann A, Bobleter O. Analysis of lignin degradation products by capillary electrophoresis. Chromatographia. 1995;40:51-7.

[234] Falco C, Sevilla M, White RJ, Rothe R, Titirici MM. Renewable Nitrogen - Doped Hydrothermal Carbons Derived from Microalgae. ChemSusChem. 2012;5:1834-40.

[235] Zhao P, Chen H, Ge S, Yoshikawa K. Evaluation of NO Emission from Combustion of Sewage Sludge with or without Hydrothermal Pretreatment. The 5th International Conference on Applied Energy. Pretoria, South Africa2013. p. Id. ICAE2013-128.

[236] Reza MT, Lynam JG, Uddin MH, Coronella CJ. Hydrothermal carbonization: Fate of inorganics. Biomass Bioenerg. 2013;49:86-94.

[237] Van Krevelen D. Graphical-statistical method for the study of structure and reaction processes of coal. Fuel. 1950;29:269-84. 
1680

1681

1682

1683

1684

1685

1686

1687

1688

1689

1690

1691

1692

1693

1694

1695

1696

1697

1698

1699

1700

1701

1702

1703

1704

1705

1706

1707

1708

1709

1710

1711

1712

1713

1714

1715

1716

1717

1718

1719

1720

1721

[238] Schuhmacher J, Huntjens F, Van Krevelen D. Chemical structure and properties of coal XXVI-studies on artificial coalification. Fuel. 1960;39:223-34.

[239] Yokokawa C, Kajiyama S, Takegami Y. Studies on the chemical structure of coal III-oxidative degradation of artificial coal. Fuel. 1964;43:21.

[240] Yu J, Savage PE. Decomposition of formic acid under hydrothermal conditions. Ind Eng Chem Res. 1998;37:2-10.

[241] Bergins C. Kinetics and mechanism during mechanical/thermal dewatering of lignite ${ }^{\text {负 }}$. Fuel. 2003;82:355-64.

[242] Clayton S, Scholes O, Hoadley A, Wheeler R, McIntosh M, Huynh D. Dewatering of biomaterials by mechanical thermal expression. Dry Technol. 2006;24:819-34.

[243] Bergins C, Berger S, Strauss K. Dewatering of fossil fuels and suspensions of ultrafine particles by mechanical/thermal dewatering. Chem Eng Technol. 1999;22:923-7.

[244] Hulston J, Favas G, Chaffee AL. Physico-chemical properties of Loy Yang lignite dewatered by mechanical thermal expression. Fuel. 2005;84:1940-8.

[245] Mihoubi D. Mechanical and thermal dewatering of residual sludge. Desalination. 2004;167:135-9.

[246] Lee JE. Thermal dewatering (TDW) to reduce the water content of sludge. Dry Technol. 2006;24:225-32.

[247] Bicker M, Hirth J, Vogel H. Dehydration of fructose to 5-hydroxymethylfurfural in sub-and supercritical acetone. Green Chem. 2003;5:280-4.

[248] Snåre M, Kubičková I, Mäki-Arvela P, Eränen K, Wärnå J, Murzin DY. Production of diesel fuel from renewable feeds: kinetics of ethyl stearate decarboxylation. Chem Eng J. 2007;134:29-34.

[249] Karayıldırım T, Sınağ A, Kruse A. Char and coke formation as unwanted side reaction of the hydrothermal biomass gasification. Chem Eng Technol. 2008;31:1561-8.

[250] Kruse A, Maniam P, Spieler F. Influence of proteins on the hydrothermal gasification and liquefaction of biomass. 2. Model compounds. Ind Eng Chem Res. 2007;46:87-96.

[251] Dinjus E, Kruse A, Tröger N. Hydrothermal carbonization-1. Influence of lignin in lignocelluloses. Chem Eng Technol. 2011;34:2037-43.

[252] Zhang M, Yang H, Liu Y, Sun X, Zhang D, Xue D. Hydrophobic precipitation of carbonaceous spheres from fructose by a hydrothermal process. Carbon. 2012;50:2155-61.

[253] Reza MT, Yan W, Uddin MH, Lynam JG, Hoekman SK, Coronella CJ, et al. Reaction kinetics of hydrothermal carbonization of loblolly pine. Bioresour Technol. 2013;139:161-9.

[254] Ohki A, Xie X-F, Inakajima T, Itahara T, Maeda S. Change in properties and combustion characteristics of an Indonesian low-rank coal due to hydrothermal treatment. Coal Perparation. 1999;21:23-34.

[255] Ge SF, Zhao PT. Effect of Thermal Conditioning on Combustion and Pollutant Emissions Characteristics of Sewage Sludge. Adv Mater Res. 2013;726:2030-5.

[256] Erlach B, Harder B, Tsatsaronis G. Combined hydrothermal carbonization and gasification of biomass with carbon capture. Energy. 2012;45:329-38.

[257] Tremel A, Stemann J, Herrmann M, Erlach B, Spliethoff H. Entrained flow gasification of biocoal from hydrothermal carbonization. Fuel. 2012;102:396-403.

[258] Dong L, Gao S, Song W, Xu G. Experimental study of NO reduction over biomass char. Fuel Process Technol. 2007;88:707-15. 
1722

[259] Dong L, Gao S, Xu G. NO reduction over biomass char in the combustion process. Energ Fuel. 2009;24:446-50.

[260] Spliethoff H, Greul U, Rüdiger H, Hein KRG. Basic effects on $\mathrm{NO}_{\mathrm{x}}$ emissions in air staging and reburning at a bench-scale test facility. Fuel. 1996;75:560-4.

[261] Morohashi Y, Yamane R, Yoshikawa K. High efficiency dehydration of sewage sludge by the hydrothermal treatment and the press filter. The $26^{\text {th }}$ Annual International Conference on Incineration and Thermal Treatment Technologies. Phoenix, AZ, USA.2007.

[262] Miyamae S, Kiga T, Ikebe H, Suzuki H. $\mathrm{NO}_{x}$ and unburned carbon simulation technologies on pilverized coal-firing boiler. Ishikawajima-harima Eng Rev. 1987;27:152-7.

[263] Sikkema R, Steiner M, Junginger M, Hiegl W, Hansen MT, Faaij A. The European wood pellet markets: current status and prospects for 2020. Biofuel Bioprod Bior. 2011;5:250-78.

[264] General Office of the State Council of the People's Republic of China. The China's 12th Five-Year Construction Plan for National Urban Wastewater Treatment and Recycling Facilities. April 5th, 2012.

[265] Elsevier. Paper relating to energy recoving from waste in Elsevier: taking sludge as an example. Elsevier; 2013.

[266] Metcalf L, Eddy H, Tchobanoglous G. Wastewater engineering: treatment, disposal, and reuse. 4th Ed. ed: McGraw-Hill; 2010.

[267] Fytili D, Zabaniotou A. Utilization of sewage sludge in EU application of old and new methods-a review. Renew Sust Energ Rev. 2008;12:116-40.

[268] Programme UNE. General source of MSW and types of wastes. 2013.

[269] Elsevier. Annually published research articles on the application HT carbonization or upgrading. Elsevier; 2013.

\section{Biographies}

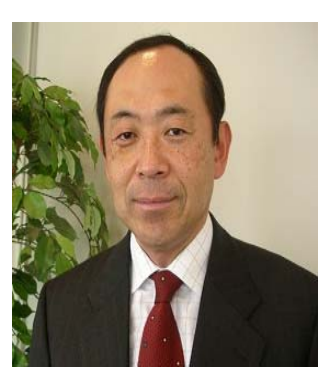

Kunio Yoshikawa

Dr. Kunio Yoshikawa is a professor of Frontier Research Center, Tokyo Institute of Technology, Japan, from where he received his $\mathrm{PhD}$ in 1986. His research areas are energy conversion, thermal engineering, combustion, gasification, waste treatment technologies and atmospheric environmental engineering, and he wrote more than 300 papers. He was awarded the AIAA Best Paper Award in 1999, ASME James Harry Potter Gold Medal in 2001, JSME Environmental Technology Achievement Award in 2006 and the Fellow of JSME in 2008.

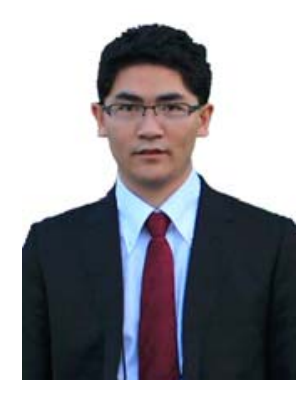

Peitao Zhao

Peitao Zhao is working as a visiting scholar in the field of Waste to Energy (WTE) in Prof. Kunio Yoshikawa's laboratory at Tokyo Institute of Technology (Japan), founded by the State Scholarship Fund of China and supported by a Strategic China-Japan Cooperative Program from 2011. He obtained his B.S. degree (2008) on Process Equipment and Control Engineering from Tianjin University of Science \& Technology (PR China). He combined his master's and doctoral courses (2009) and started his PhD in the field of WTE at Southeast University (PR China) from 2010. His main research interests are solid waste recycling and 
management, bioresource technology, pollutants emission and controls, and renewable energy. His academic papers mainly published on the energy and thermal engineering related journals, such as Applied Energy, Applied Thermal Engineering and Energy \& Fuels, etc.

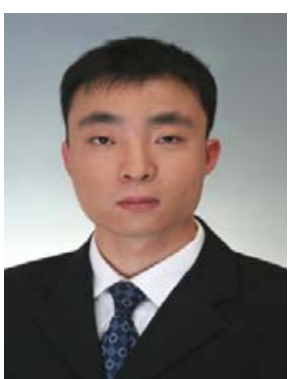

Yafei Shen

Yafei Shen obtained his B.S. degree (2009) on applied chemistry from Nanjing University of Information Science \& Technology (China). Then he received M.S. degree (2012) on environmental engineering from Shanghai Jiaotong University (China). During the master period, his research areas were environmental chemistry, energy \& chemical engineering, especially in clean coal technology and flue gas desulfurization (FGD). Currently he has been a PhD student in Prof. Kunio Yoshikawa's laboratory at Tokyo Institute of Technology (Japan), founded by the State Scholarship Fund of China. His main research interests are solid waste management, bioresource technology and tar elimination during biomass gasification. His academic papers mainly published on the energy and chemistry related international journals of Renewable and Sustainable Energy Reviews, Fuel and Energy \& Fuels, etc. 


\section{Figures's captions}

Fig.1 Typical composition of MSW, (a) United States, data adapted from U.S. EPA [94]; (b) by region, data derived from [95] "The World Bank, 2012, source: http://data.worldbank.org/"

Fig.2 A conceptual schematic of clean solid biofuel from bio-wastes

Fig.3 Effect of the operating parameters on the sewage sludge dewatering: (a) Holding time; (b) Temperature. (References: Fisher and Swanwick [167], Jiang et al., [168] Zhao et al. [173] and Xun et al. [174] focusing on the sewage sludge; Areeprasert et al. [161] using paper sludge and Zhang et al. [163] using mycelial waste) (SRF: specific resistance to filtration)

Fig.4 Overall dewatering performance of the hydrothermal pretreated paper sludge (including the mechanical de watering and thermal evaporation). Data from (Zhao, unpublished data)

Fig.5 An illustration of the upgrading of some typical and low rank coal. Data derived from these typical references: Liu et al.[46] Cocout and Eucalyptus leaves (holding time: 30 minutes), Mursito et al.[60] Indonesia tropical peat (holding time: 30 minutes), Sagakuchi et al.[184] Australia Loy Yang coal (holding time as 30 minutes: Brown coal-1 and 180 minutes: Brown coal-2), Yuliansyah et al.[106] Oil palm waste, such as Trunk and Frond (holding time: 30 minutes), Guo et al.[181] Victorian Loy Yang coal (holding time: 20 minutes), Lu et al.[66] Indonesia MSW, Chinese MSW and Japanese MSW at $220^{\circ} \mathrm{C}$ and 30 minutes, Hwang et al.[75] Paper, Dog food and Wood, Ge et al.[162] Japanese sewage sludge (holding time: 1, 30 minutes and 2, 45 minutes), Areeprasert et al.[161] Thailand paper sludge (holding time: 30 minutes) and Prawisudha et al.[62] Japanese MSW (holding time: 90 minutes).

Fig.6 The $\mathrm{Cl}$ behavior during the HT process. Data adapted from ref.[62].

Fig.7 Feasibility of the water reuse during washing process. Data adapted from refs.[34, 68].

Fig.8 Nitrogen content varying with the HT temperature. Data adapted from refs.[112, 161, 163, $229,235]$.

Fig.9 Distribution of nitrogen following the HT temperature. Data adapted from ref.[163]

Fig.10 Van Krevelen diagram for the solid fuel production from bio-wastes by the HT at different temperatures in comparison with other solid fuel. Data adapted from Ge et al. [162] Japanese sewage sludge (holding time: 30 minutes), Liu et al. [46] Cocout (holding time: 30 minutes), Mursito et al. [60] Indonesia tropical peat (holding time: 30 minutes), Zhang et al. [163] mycelial waste (holding time: 30 minutes), Areeprasert et al. [161] paper sludge (holding time: 30 minutes), Gao et al. [151] cellulose (holding time: 30 minutes), Wiedner et al. [231] wheat straw, poplar and olive oil residues (holding time: $8 \mathrm{~h}$ ), Yuliansyah et al. [106] Oil palm waste-trunk and Frond (holding time: 30 minutes), Liu et al. [46] Cocout (holding time: 30 minutes), Kim et al. [69] Kimchi and paper (holding time: about 30 minutes) and Berge et al. [112] MSW and anaerobic digested sludge (holding time: about $50 \mathrm{~h}$ ). 
Fig.11 Dehydration of D-fructose to 5-hydroxymethyfurfural [247] and decarboxylation stearic acid to diesel products [248].

Fig.12 schematic clean solid biofuel formation pathways in HT of bio-wastes

Fig.13 Comparison of NO emission from RS and HTS for different combustion modes (RS: raw sludge; CC: conventional combustion; DC: decoupling combustion; SC: separated combustion; AC: air-stage combustion)

Fig.14 Energy balance of solid fuel production by HT pretreatment $\left(200{ }^{\circ} \mathrm{C}\right.$ for 30 minutes $)$

\section{Tables' captions}

Table 1 Sludge production of some typical countries $\left(\times 10^{6} \mathrm{~kg} / \mathrm{year}\right)$, data derived from refs. [52, 80-82].

Table 2 MSW generation within the OECD area and China mainland $\left(\times 10^{6} \mathrm{~kg} /\right.$ year $)$

Table 3 Fuel properties of MSW within some typical countries.

Table 4 Proximate and ultimate analysis of EFB from Thailand, Indonesia, and Malaysia. Data adapted from ref. [102] for Indonesia, ref. [97] for Thailand, and ref. [103] for Malaysia.

\section{Figures}
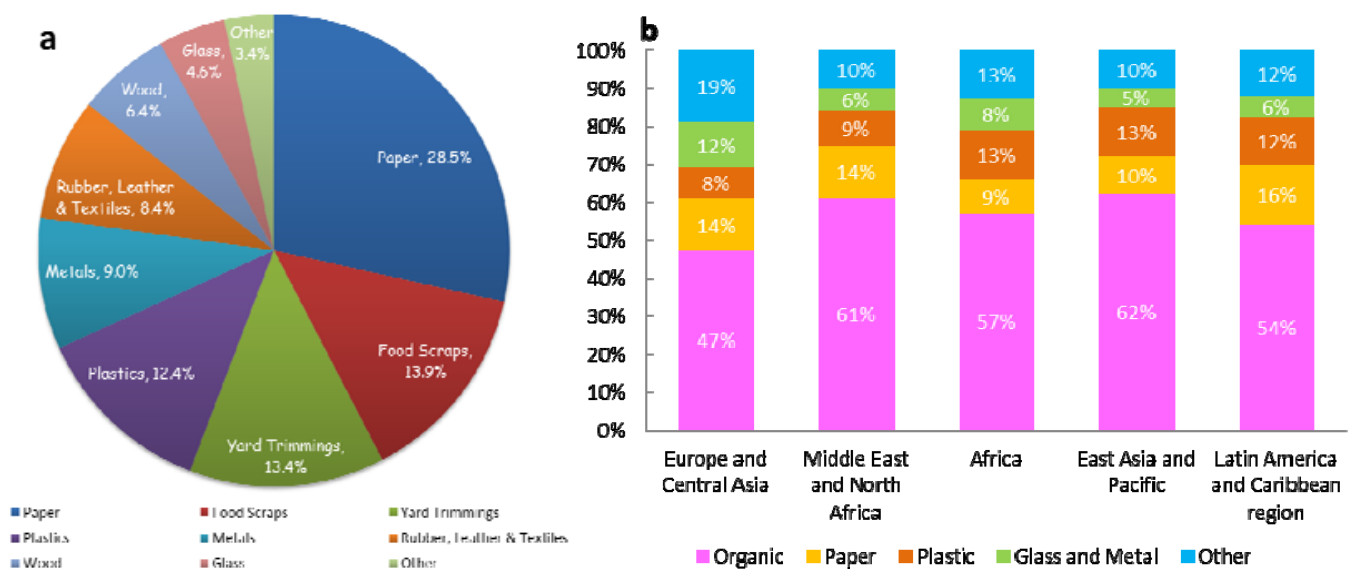

Fig.1 
Conventional thermal-conversion technologies

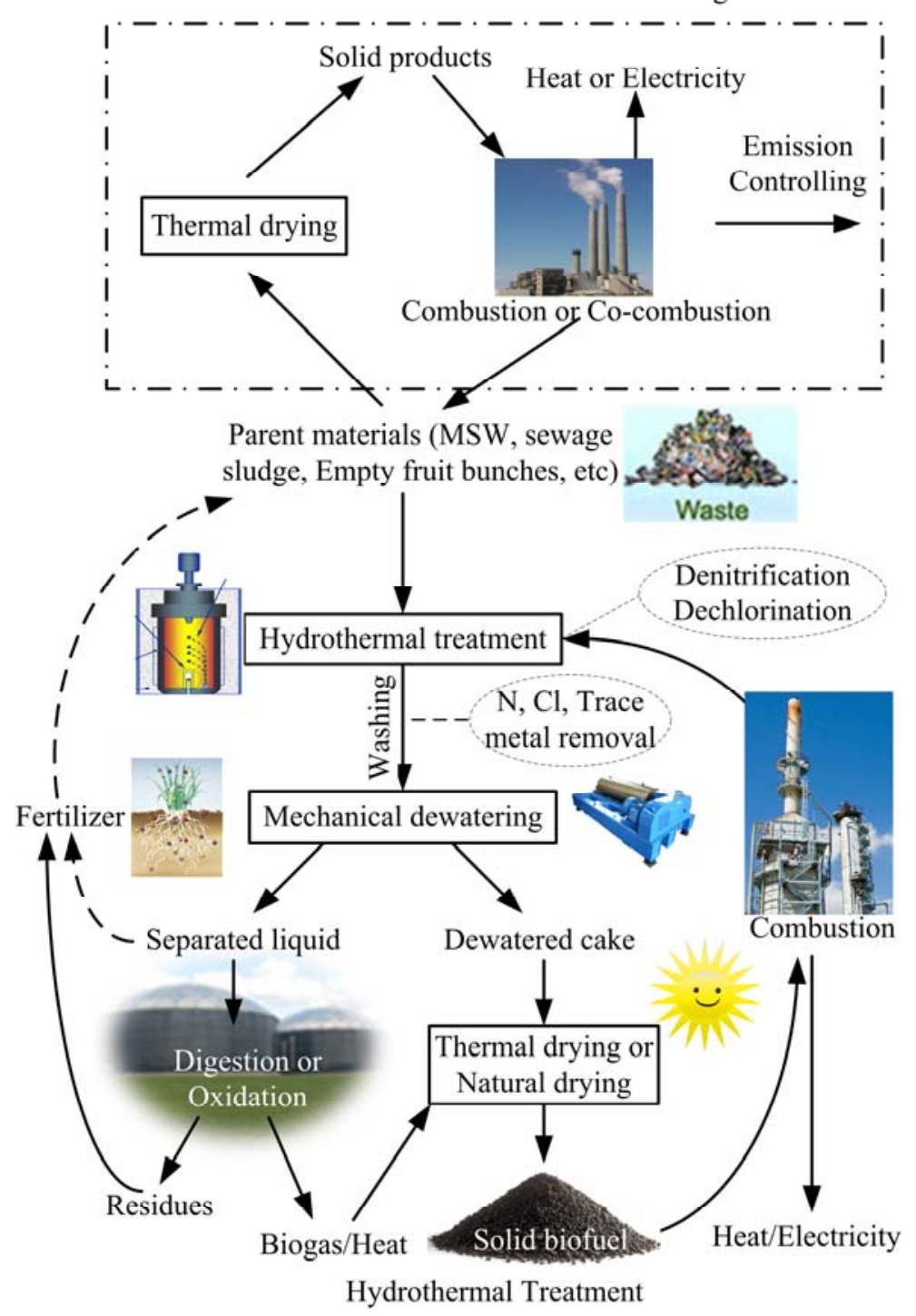

Fig. 2 

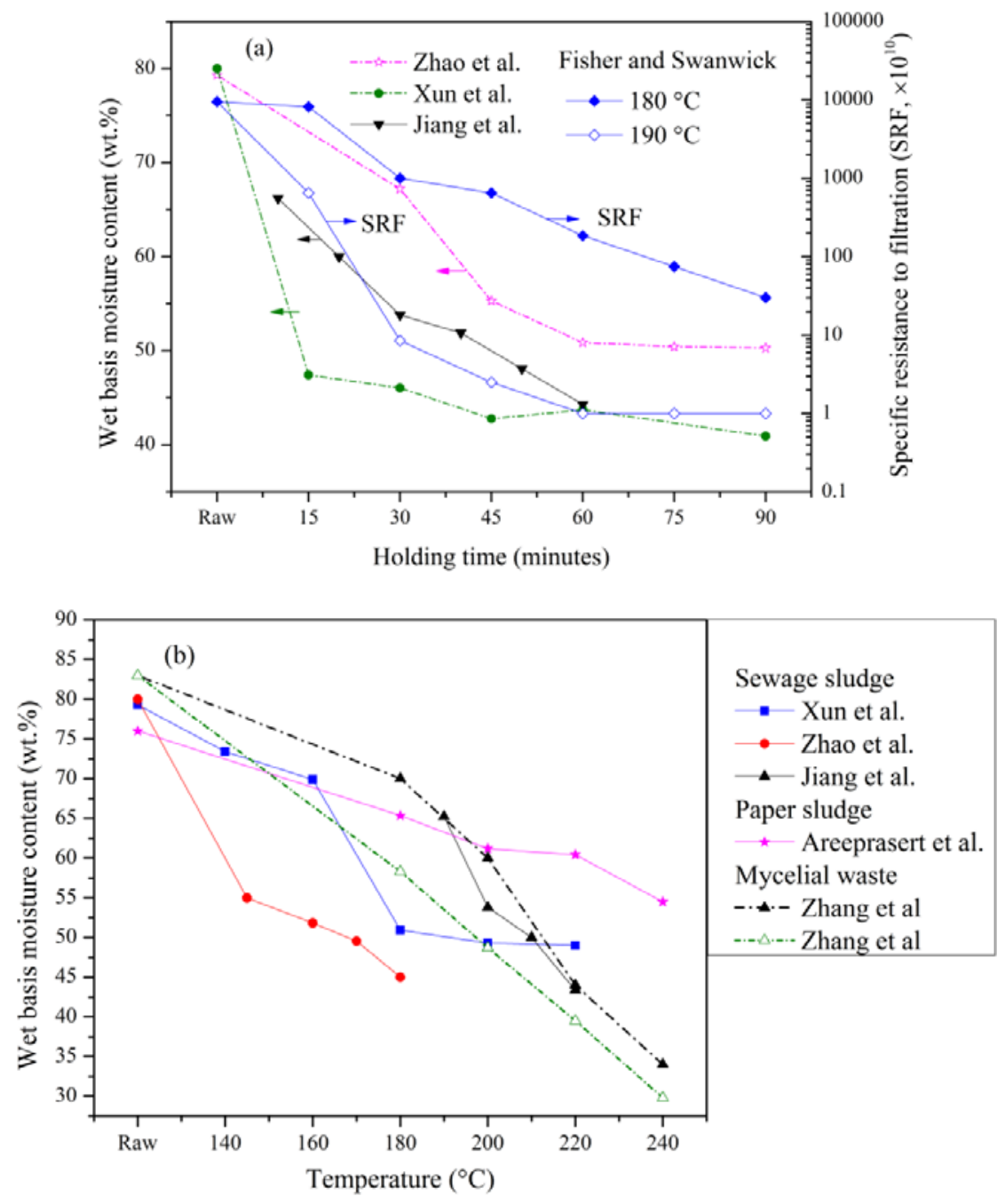

Fig.3 


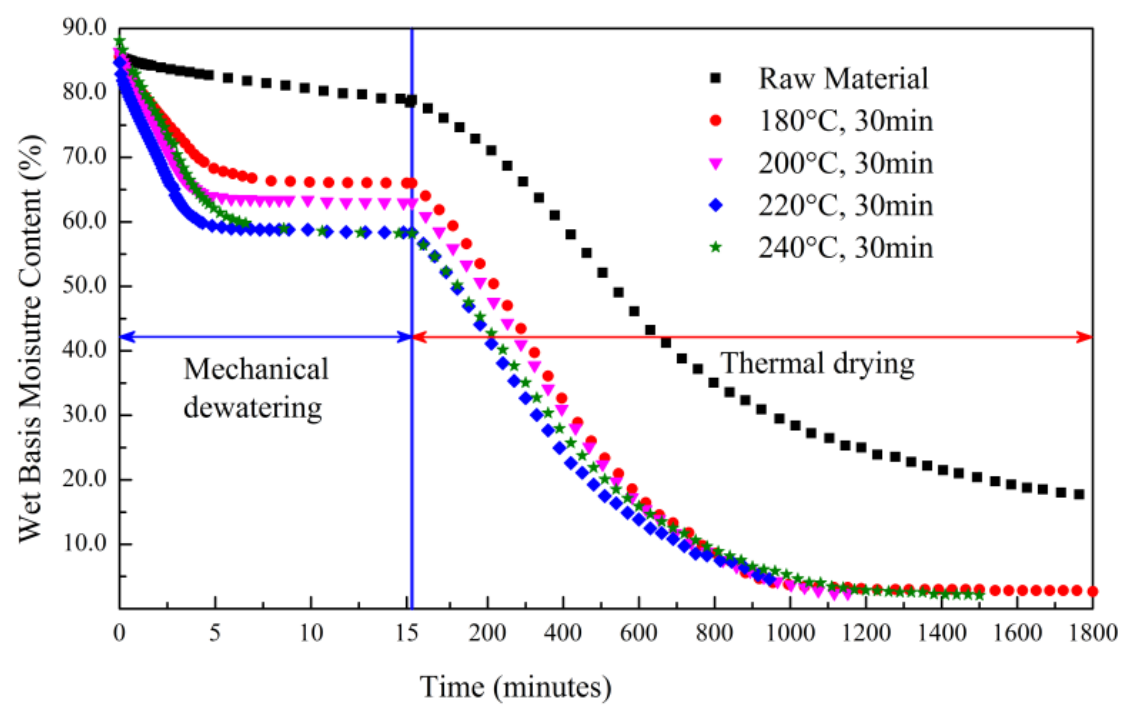

Fig.4

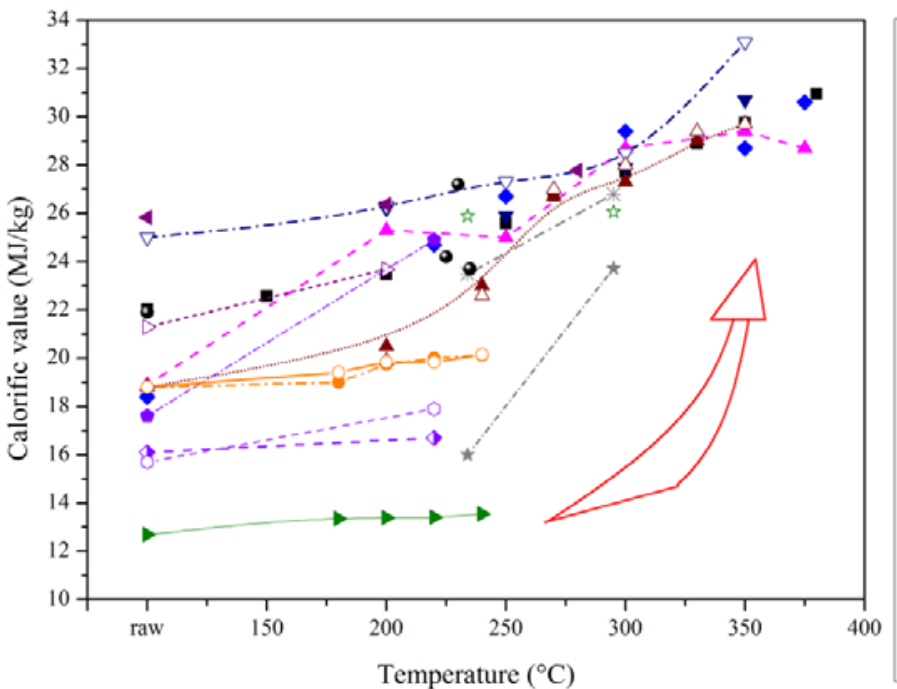

- Tropical peat, Mursito et al.

- Cocout, Liu et al.

- - Eucalyptus leaves, Liu et al.

v Brown coal-1, Sakaguchi et al.

$-\cdot \nabla-$ Brown coal-2, Sakaguchi et al.

- Brown coal, Guo et al.

$\cdots \triangleright \cdots$ Bowmans, Guo et al.

^ Frond, Yuliansyah et al.

$\triangle$ Trunk, Yuliansyah et al.

- - Japanese MSW, Lu et al.

-- o-- India MSW, Lu et al.

---- Chinese MSW, Lu et al.

--*-- Paper, Hwang et al.

\& Dog food, Hwang et al.

-*-* Wood, Hwang et al.

-.- Sewage sludge-1, Ge et al.

- - Sewage sludge-2, Ge et al.

$\rightarrow$ Paper sludge, Areeprasert et al.

- Msw, Prawisudha et al.

Fig.5 


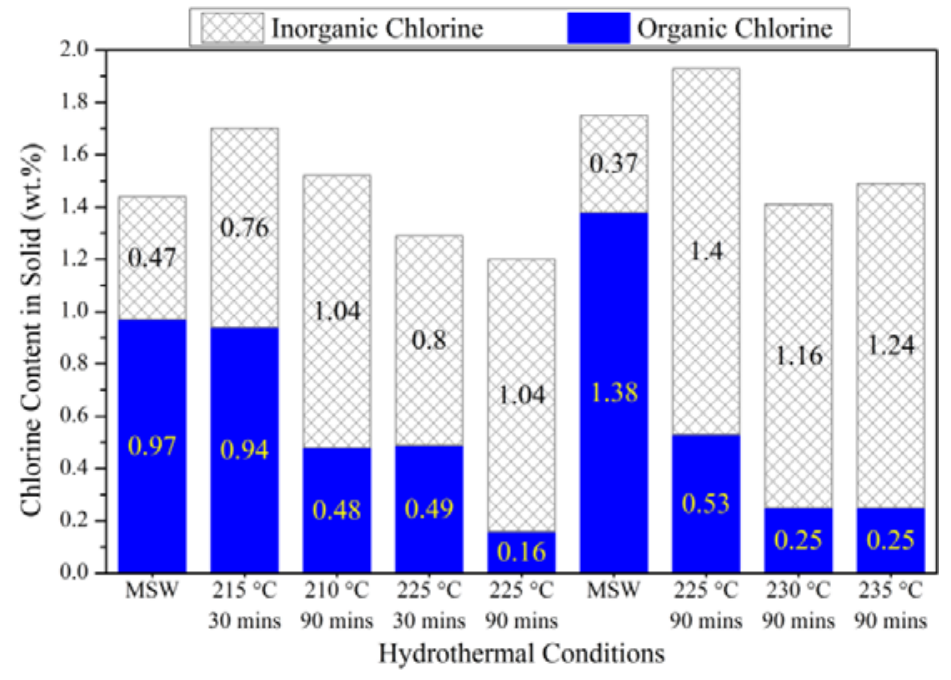

Fig.6

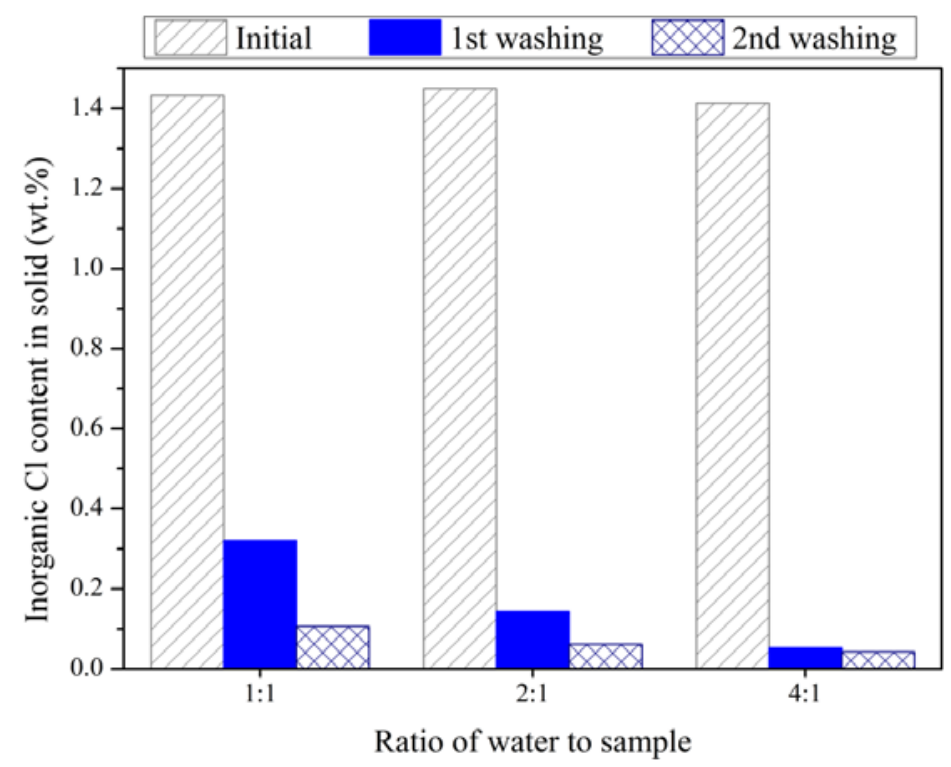

Fig.7 


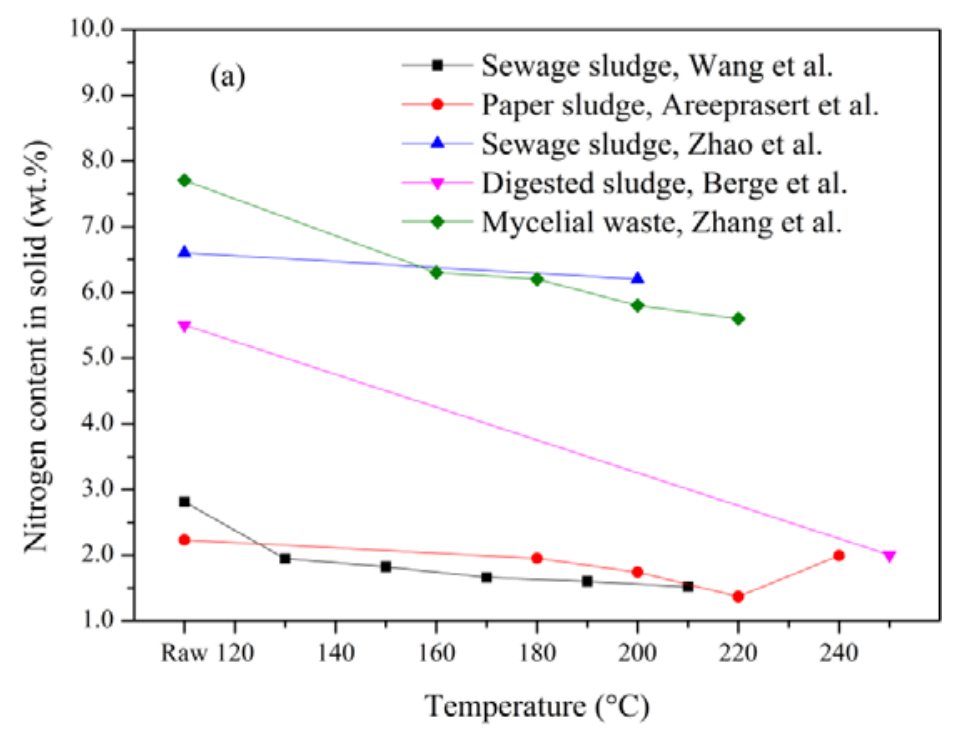

Fig.8

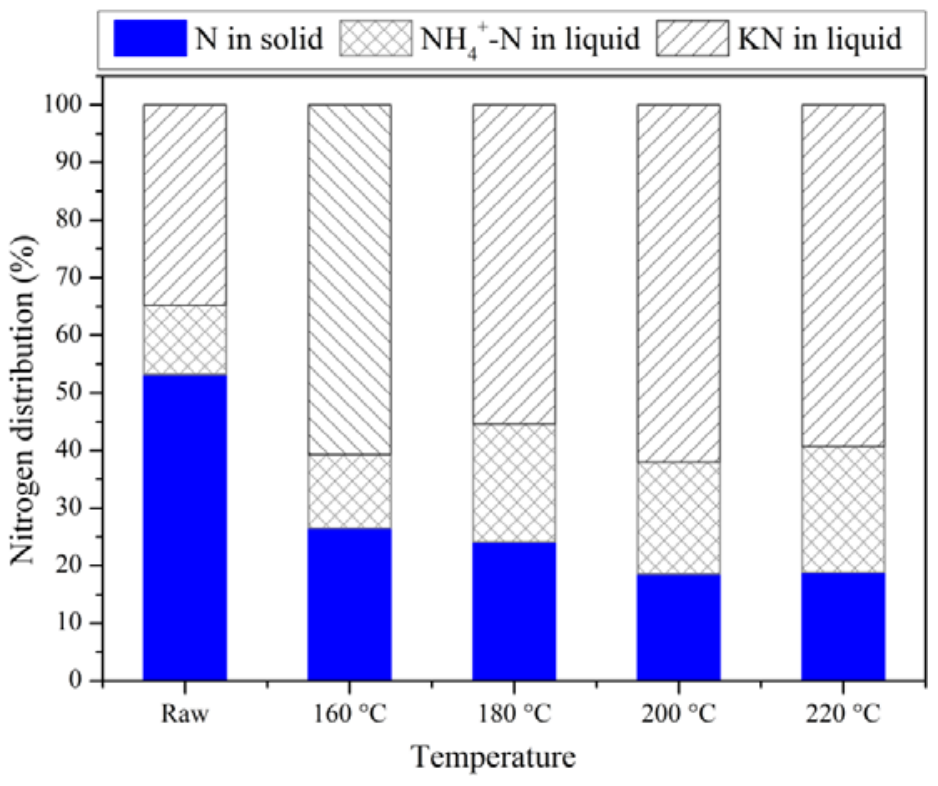

Fig.9 


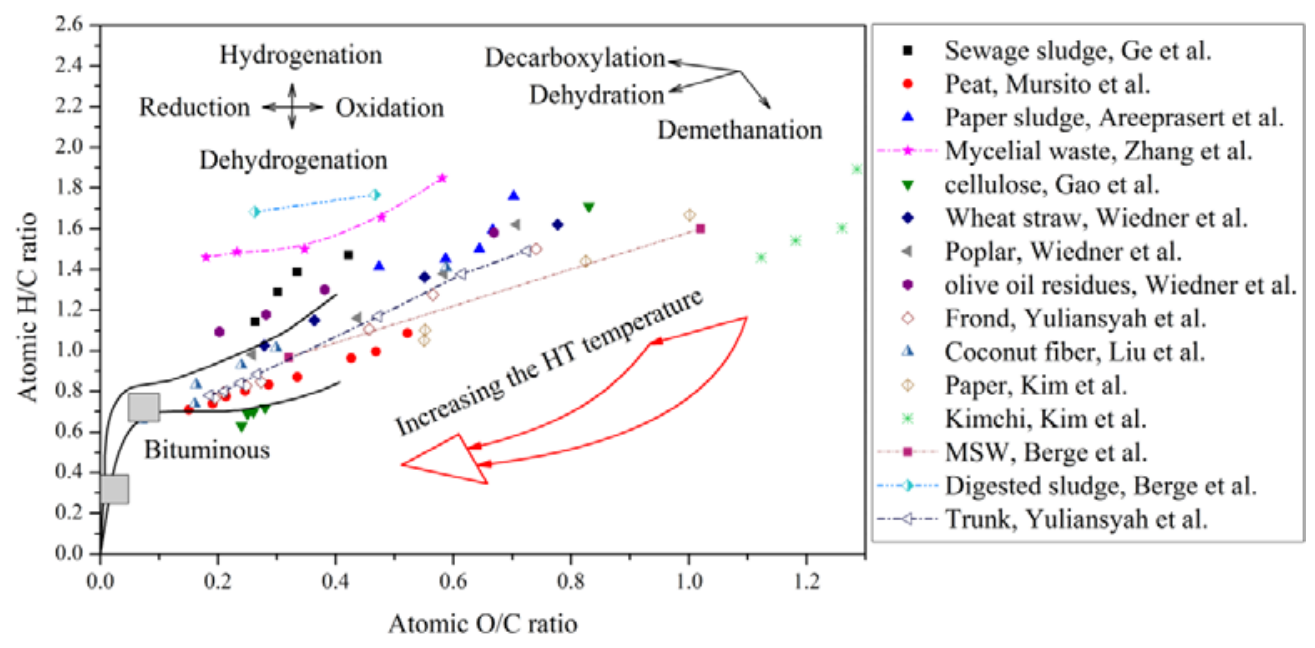

Fig. 10

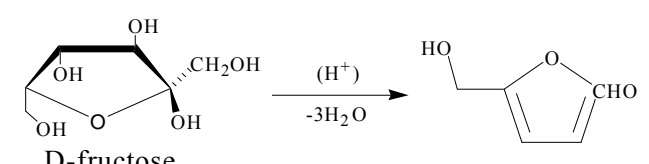

D-fructose

Dehydration

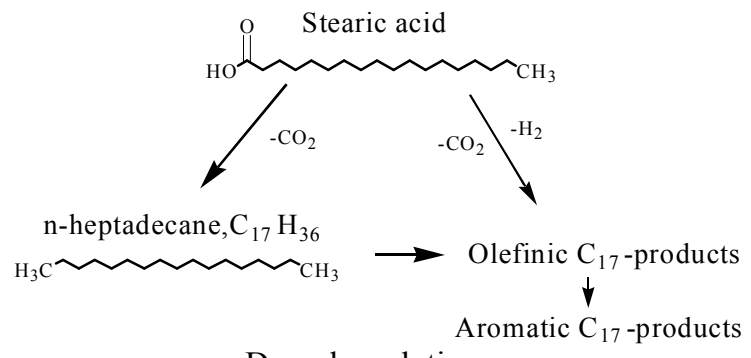

Decarboxylation

Fig.11

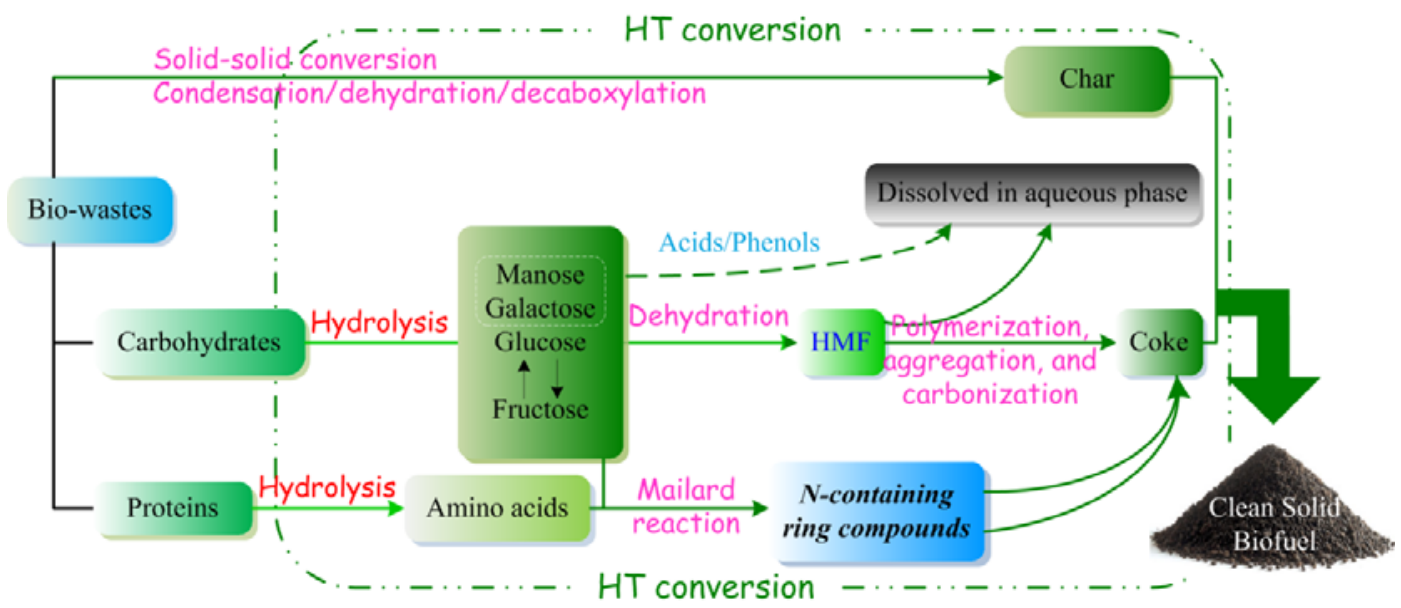

Fig. 12 


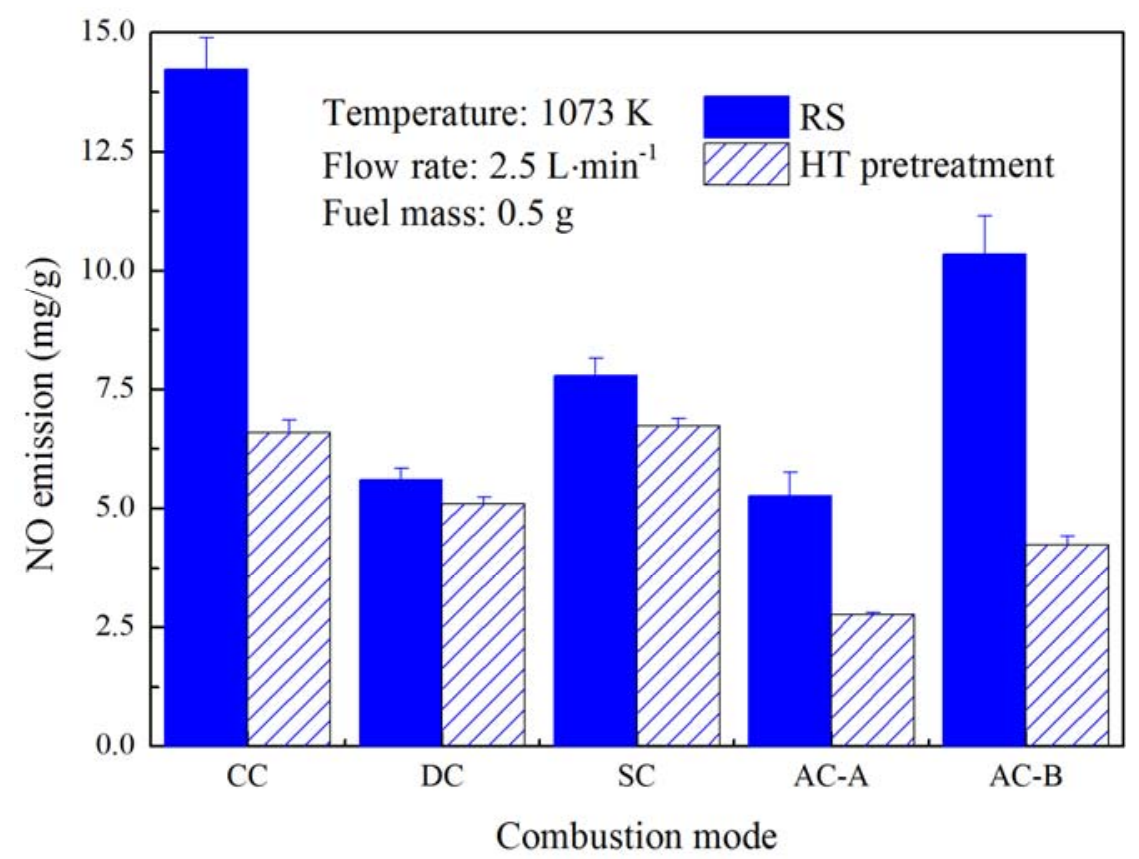

Fig. 13

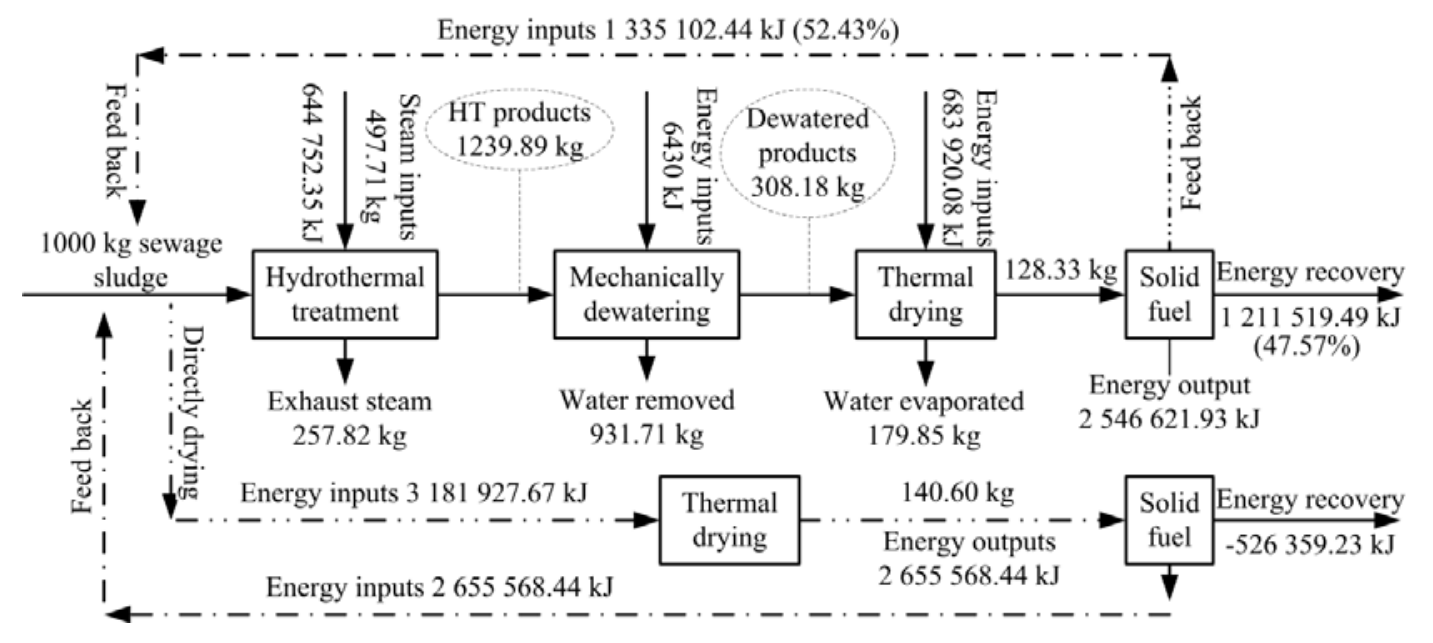

Fig.14 


\section{Tables}

Table 1 Sludge production of some typical countries $\left(\times 10^{6} \mathrm{~kg} / \mathrm{year}\right)$, data derived from refs. [52, 80-82].

\begin{tabular}{cccc}
\hline Countries(regions)/years & 2005 & 2010 & 2020 \\
\hline United Kingdom (UK) & $1,545(2006)$ & 1,640 & 1,640 \\
EU-27 total & $10,135(2006)$ & 11,564 & 13,047 \\
Japan & 2,227 & 2,300 & - \\
United States & 7,600 & 8,100 & - \\
China mainland $^{\text {a }}$ & 2,104 & 4,150 & $6,457(2015)$
\end{tabular}

${ }^{a}$ Data for China was calculated according to the statistics data of Chinese sewage drainage. Assuming that treatment every 10,000 of sewage will produce $2 \mathrm{~kg}$ of sewage sludge. Source: http://www.mep.gov.cn/zwgk/hjtj/[82] Data for 2015 was calculated according to the China's 12th Five-Year Construction Plan for National Urban Wastewater Treatment and Recycling Facilities, indicating that the daily domestic sewage treatment rate would be improved to $85 \%$. During this calculation, the amount of sewage drainage was assumed as the same as that of 2010 , referring to ref.[264].

Table 2 MSW generation within the OECD area and China mainland $\left(\times 10^{6} \mathrm{~kg} / \mathrm{year}\right)$

\begin{tabular}{lcccccccc}
\hline Regions/years & 1980 & 1995 & 2000 & 2005 & 2015 & 2020 & 2030 & Increase rate \\
\hline OECD total & 3,950 & 5,610 & 6,240 & 6,530 & 7,540 & 8,000 & 9,000 & $1.3 \%$ \\
(kg/capita/year) & 376 & 476 & 512 & 522 & 576 & 600 & 658 & \\
OECD Pacific & 120 & 150 & 160 & 170 & 190 & 200 & 220 & $1.1 \%$ \\
OECD Asia & 550 & 680 & 690 & 740 & 840 & 880 & 970 & $1.1 \%$ \\
OECD Nafta & 1,640 & 2,420 & 2,720 & 2,840 & 3,260 & 3,470 & 3,890 & $1.3 \%$ \\
OECD Europe & 1,700 & 2,360 & 2,670 & 2,790 & 3,280 & 3,520 & 4,000 & $1.5 \%$ \\
United States & $1,211(1970)$ & 2,173 & 2,425 & 2,527 & $2,499(2010)$ & - & - & $4.7 \%{ }^{\mathrm{a}}$ \\
China mainland & 310 & $690(1990)$ & 1,200 & 1,580 & 1,800 & $2,100(2015)$ & 4,850 & $8-10 \%$ \\
\hline
\end{tabular}

OECD: Organization for Economic Co-operation and Development, Nafta: North American Free Trade Agreement, data for United States comes from United States Environmental Protection Agency (U.S. EPA) [94]. Data for OECD and China mainland comes from Cheng et al. and European Environment Agency (Source: OECD Environmental Outlook Baseline) [50, 90]. 
Table 3 Fuel properties of MSW within some typical countries.

\begin{tabular}{|c|c|c|c|c|c|c|c|c|}
\hline \multicolumn{2}{|c|}{ Items/Composition $(\%, \mathrm{db})$} & Plastics & Food & Paper & Wood & Textiles & Inert & Total $(\%)$ \\
\hline \multicolumn{2}{|c|}{ Chinese MSW } & 13.0 & 58.8 & 12.8 & 9.1 & 4.4 & 1.9 & 100 \\
\hline \multicolumn{2}{|c|}{ Japanese MSW } & 6.8 & 35.9 & 42.9 & 9.0 & 4.4 & 1.0 & 100 \\
\hline \multicolumn{2}{|c|}{ Indian MSW } & 4.0 & 0 & 27.2 & 40.8 & 5.7 & 22.3 & 100 \\
\hline \multicolumn{9}{|c|}{ Fuel properties } \\
\hline Items/properties & $\begin{array}{l}\text { Density }^{\mathrm{a}} \\
\left(\mathrm{kg} / \mathrm{m}^{3}\right)\end{array}$ & $\begin{array}{c}M_{w}{ }^{\mathrm{a}} \\
(\%, \mathrm{wt})\end{array}$ & $\begin{array}{c}M_{v m} \\
(\%, \mathrm{db})\end{array}$ & $\begin{array}{c}M_{f c} \\
(\%, \mathrm{db})\end{array}$ & $\begin{array}{c}M_{a s h} \\
(\%, \mathrm{db})\end{array}$ & $\begin{array}{c}\text { Mass based HV } \\
(\mathrm{MJ} / \mathrm{kg}, \mathrm{db})\end{array}$ & & $\begin{array}{l}\text { Volume based } \\
\mathrm{IV}\left(\mathrm{MJ} / \mathrm{m}^{3}, \mathrm{db}\right)\end{array}$ \\
\hline Chinese MSW & 110 & 30.4 & 80.1 & 8.3 & 11.6 & 17.6 & & 1,936 \\
\hline Japanese MSW & 110 & 32.0 & 85.3 & 4.5 & 10.2 & 16.1 & & 1,771 \\
\hline Indian MSW & 120 & 30.2 & 77.2 & 9.2 & 13.6 & 15.7 & & 1,884 \\
\hline
\end{tabular}

a: as received; $M_{w}$, moisture content; $M_{v m}$, volatile matters; $M_{f c}$, fix carbon; $M_{a s h}$, ash content; HV, heating value. Data derived from ref.[66].

Table 4 Proximate and ultimate analysis of EFB from Thailand, Indonesia, and Malaysia. Data adapted from ref. [102] for Indonesia, ref. [97] for Thailand, and ref. [103] forMalaysia.

\begin{tabular}{lccc}
\hline Items/sample origins & Thailand & Indonesia. & Malaysia \\
\hline Proximate analysis & \multicolumn{3}{c}{} \\
Moisture (wt. \%) & $8.34^{\mathrm{a}}$ & $0.65^{\mathrm{b}}$ & $8.75^{\mathrm{a}}$ \\
Volatile matter (wt.\%) & 73.16 & 77.41 & 79.65 \\
Fix carbon (wt.\%) & 12.2 & 17.42 & 8.6 \\
Ash (wt.\%) & 6.3 & 4.52 & 3.0 \\
Ultimate analysis (dry ashes free, daf, \%) & \\
$\mathrm{C}$ & 46.74 & 51.51 & 50.30 \\
$\mathrm{H}$ & 6.62 & 7.33 & 7.56 \\
$\mathrm{O}$ & 45.51 & 40.42 & 41.42 \\
$\mathrm{~N}$ & 0.47 & 0.67 & 0.00 \\
$\mathrm{~S}$ & 0.10 & 0.07 & 0.70 \\
Others & 0.57 & 0.0 & 0.02 \\
Heating value (MJ/kg) & 19.24 & 21.33 & 18.96 \\
\hline a air dried basis & \multicolumn{4}{l}{} \\
${ }^{\mathrm{b}}$ Mean water content of empty fruit bunches after steam sterilization
\end{tabular}




\section{Captions for Support Information}

S1 Paper relating to energy recoving from waste in Elsevier [265]

S2 Typical chemical composition and properties of untreated/digested sludge, data adapted from ref.[266, 267].

S3 General source of MSW and types of wastes [268]

S4 Annually published research articles on the application HT carbonization or upgrading [269] (source: Elsevier, http://www.elsevier.com/)

\section{Support Information}

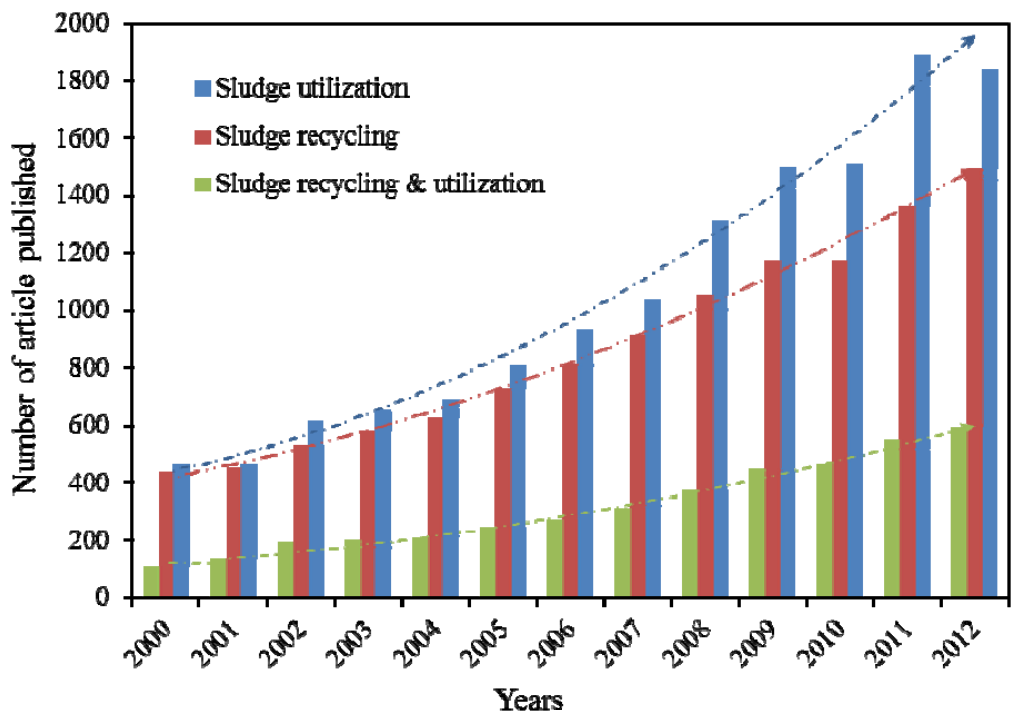

S1 Paper relating to energy recoving from waste in Elsevier [265] 
S2 Typical chemical composition and properties of untreated/digested sludge, data adapted from ref.[266, 267].

\begin{tabular}{|c|c|c|c|c|c|}
\hline \multirow{2}{*}{ Item/Sludge type } & \multicolumn{2}{|c|}{ Primary sludge } & \multicolumn{2}{|c|}{ Digested primary sludge } & \multirow{2}{*}{ Activated sludge } \\
\hline & Value range & Typical & Value range & Typical & \\
\hline $\mathrm{PH}$ & $5.0-8.0$ & 6.0 & $6.5-7.5$ & 7.0 & $6.5-8.0$ \\
\hline Solid content & $2.0-8.0$ & 5.0 & 6.0 & 12.0 & $0.83-1.16$ \\
\hline \multicolumn{6}{|l|}{ Grease and fats $(\%, \mathrm{db})$} \\
\hline Ether soluble & $6-30$ & - & $5-20$ & 18 & - \\
\hline Ether extract & $7-35$ & - & - & - & $5-12$ \\
\hline Protein $(\%, \mathrm{db})$ & $20-30$ & 25 & $15-20$ & 18 & $32-41$ \\
\hline Nitrogen $(\%, d b)$ & $1.5-4.0$ & 2.5 & $1.6-6.0$ & 3.0 & $2.4-5.0$ \\
\hline Phosphorous $\left(\mathrm{P}_{2} \mathrm{O}_{5}, \% \mathrm{db}\right)$ & $0.8-2.8$ & 1.6 & $1.5-4.0$ & 2.5 & $2.8-11.0$ \\
\hline Potash $\left(\mathrm{K}_{2} \mathrm{O}, \%, \mathrm{db}\right)$ & $0-1$ & 0.4 & $0.0-3.0$ & 1.0 & $0.5-0.7$ \\
\hline Cellulose $(\%, \mathrm{db})$ & $8.0-15.0$ & 10.0 & $8.0-15.0$ & 10.0 & - \\
\hline Iron (not as sulfide) & $2.0-4.0$ & 2.5 & $3.0-8.0$ & 4.0 & - \\
\hline Silica $\left(\mathrm{SiO}_{2}, \% \mathrm{db}\right)$ & $15.0-20.0$ & - & $10.0-20.0$ & - & - \\
\hline Alkalinity $\left(\mathrm{mg} / \mathrm{L}\right.$ as $\left.\mathrm{CaCO}_{3}\right)$ & $500-1500$ & 600 & $2500-3500$ & - & $580-1100$ \\
\hline Organic acid (mg/L as HAC) & $200-2000$ & 500 & $100-600$ & 3000 & $1100-1700$ \\
\hline Volatile $(\%, \mathrm{db})$ & $60-80$ & 65 & $30-60$ & 40 & $59-88$ \\
\hline Heating value (MJ/kg, db) & $23-29$ & 25.5 & $14-18$ & 16 & $16-23$ \\
\hline
\end{tabular}

S3 General source of MSW and types of wastes [268]

\begin{tabular}{|c|c|c|}
\hline Sources & Typical waste generators & Types of solid waste \\
\hline Residential & Single and multifamily dwellings & $\begin{array}{l}\text { Paper, cardboard, food wastes, plastics, textiles, glass, } \\
\text { metal ashes, special wastes (bulky item consumer } \\
\text { electronics, batteries, oil and tires) and household } \\
\text { hazardous wastes, etc. }\end{array}$ \\
\hline $\begin{array}{l}\text { Commercial } \\
\& \text { Institutional } \\
\text { Municipal } \\
\text { services }\end{array}$ & $\begin{array}{l}\text { Stores, hospitals markets, } \\
\text { Schools, restaurants, etc. } \\
\text { Street cleaning, garden, parks, } \\
\text { beaches, recreational areas, etc. }\end{array}$ & $\begin{array}{l}\text { Paper, wood, cardboard, food wastes, plastics, metals, } \\
\text { glass, special wastes, hazardous wastes, wood residues, etc. } \\
\text { landscape and tree trimmings, Street sweeping, generation } \\
\text { wastes from park, beaches and other recreational areas, etc. }\end{array}$ \\
\hline Component & \multicolumn{2}{|l|}{ Description } \\
\hline Food wastes & \multicolumn{2}{|c|}{$\begin{array}{l}\text { The animal, fruit, or vegetable residues (also called garbage) resulting from the handling, } \\
\text { preparation, cooking and eating of foods. Because food wastes are putrescible, they will } \\
\text { decompose rapidly, especially in warm weather. }\end{array}$} \\
\hline Rubbish & \multicolumn{2}{|c|}{$\begin{array}{l}\text { Combustible and non-combustible solid wastes, excluding food wastes or putrescible materials. } \\
\text { Typically combustible rubbish consists of materials such as paper, cardboard, plastics, textiles, } \\
\text { rubber, leather, wood, furniture, and garden trimmings. Non- combustible rubbish consists of } \\
\text { items such as glass, crockery, tin cans, aluminum cans, ferrous and non-ferrous metals, and } \\
\text { construction material. }\end{array}$} \\
\hline
\end{tabular}

Sources: http://www.unep.org/ietc/InformationResources/Publications/tabid/56265/Default.aspx\#WastePubTop 


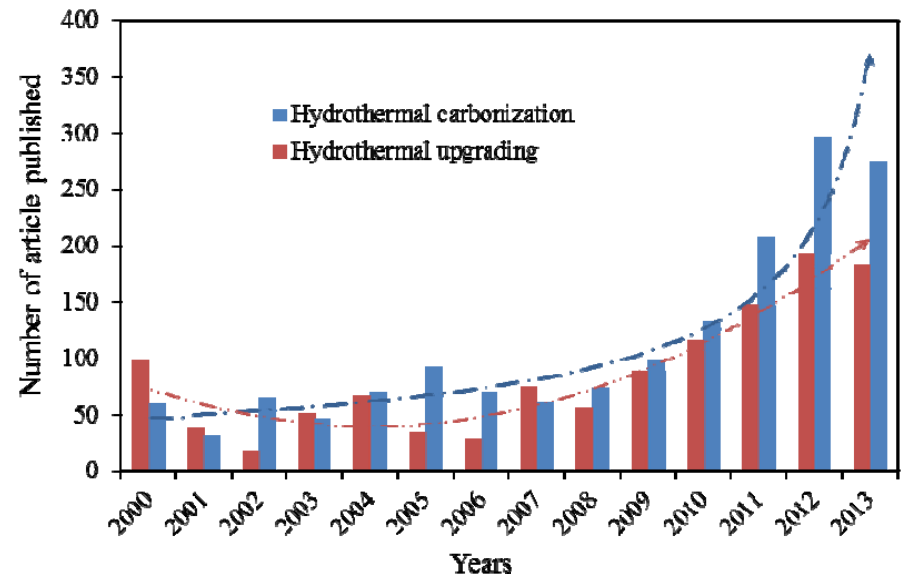

S4 Annually published research articles on the application HT carbonization or upgrading [269] (source: Elsevier, http://www.elsevier.com/) 